FÁBIO YUGO FUJII

ANÁLISE COMPARATIVA ENTRE O PROCESSO DE LODO ATIVADO E O REATOR DE BIOFILME DE LEITO MÓVEL NA REMOÇÃO DE NITROGÊNIO DE ESGOTO SANITÁRIO. 
FÁBIO YUGO FUJII

\section{ANÁLISE COMPARATIVA ENTRE O PROCESSO DE LODO ATIVADO \\ E O REATOR DE BIOFILME DE LEITO MÓVEL NA REMOÇÃO DE NITROGÊNIO DE ESGOTO SANITÁRIO.}

Dissertação apresentada à Escola Politécnica da Universidade de São Paulo para obtenção do título de Mestre em Engenharia 
FÁBIO YUGO FUJII

\section{ANÁLISE COMPARATIVA ENTRE O PROCESSO DE LODO ATIVADO E O REATOR DE BIOFILME DE LEITO MÓVEL NA REMOÇÃO DE NITROGÊNIO DE ESGOTO SANITÁRIO.}

Dissertação apresentada à Escola Politécnica da Universidade de São Paulo para obtenção do título de Mestre em Engenharia

Área de Concentração:

Engenharia Hidráulica e Sanitária

Orientador: Prof. Livre Docente Roque Passos Piveli 
Este exemplar foi revisado e alterado em relação à versão original, sob responsabilidade única do autor e com a anuência de seu orientador.

São Paulo, 04 de novembro de 2011.

Assinatura do autor

Assinatura do orientador

FICHA CATALOGRÁFICA

Fujii, Fábio Yugo

Análise comparativa entre o processo de lodo ativado e o reator de biofilme de leito móvel na remoção de nitrogênio de esgoto sanitário / F.Y. Fujii. - ed.rev. -- São Paulo, 2011.

$109 \mathrm{p}$.

Dissertação (Mestrado) - Escola Politécnica da Universidade de São Paulo. Departamento de Engenharia Hidráulica e Sanitária.

1. Esgotos sanitários (Tratamento) 2. Lodo ativado 3. Reatores de leito fluidificado 4. Biofilmes I. Universidade de São Paulo. Escola Politécnica. Departamento de Engenharia Hidráulica e Sanitária II. t. 


\section{AGRADECIMENTOS}

Ao Professor Roque Passos Piveli pela orientação e produção executiva dos trabalhos da equipe de pesquisa, pelo esforço para fazer o projeto avançar, resistindo às dificuldades que progressivamente foram nos desafiando, muitas vezes parecendo maiores que a nossa capacidade de superá-las. Agradeço muito pela confiança depositada em mim e pela compreensão incondicional.

Agradeço também ao Professor Pedro Alem Sobrinho pelos aconselhamentos e pela permissão do uso da estação piloto que já havia vivido outras batalhas e serviu firmemente como base para o experimento.

Meus sinceros agradecimentos ao pessoal da equipe de pesquisa, Fábio Campos, Laerte Cícero de Carvalho e Silvana Audrá Cutolo, pela imensa contribuição nessa etapa da pesquisa, e também ao Rodrigo de Freitas Bueno, sempre solidário, conduzindo o seu trabalho de mestrado.

À FAPESP que proporcionou recursos para o desenvolvimento da pesquisa.

À Sabesp e à JNS, agradeço pela concessão do uso dos suportes plásticos móveis que anteriormente foram utilizados também num experimento em escala piloto para avaliação da viabilidade de utilização da tecnologia MBBR na ETE Barueri.

À equipe da fundação FCTH, incluindo o pessoal das seções de encanamento, acrílico, elétrica, oficina mecânica e pintura, e todos os que contribuíram para a montagem das instalações experimentais e para a sua manutenção.

À minha família e outros mestres ao longo da vida a quem devo a virtude da persistência. À Aline, que esteve ao meu lado e me motivou quando precisei.

Aos amigos da JNS que acompanharam a caminhada e me ajudaram no que foi necessário para conciliar a atividade profissional à pesquisa acadêmica.

Aos amigos do Liceu de Artes e Ofícios, de um modo geral, que fizeram falta nesse tempo todo e perdoaram minha ausência. 


\section{RESUMO}

O processo de tratamento de esgoto por lodo ativado pode ser adaptado para o recebimento de maior carga orgânica ou para a remoção de nitrogênio por meio da introdução de suportes plásticos móveis, em um processo conhecido por IFAS Integrated Fixed-Film Activated Sludge.

O objetivo do projeto é avaliar comparativamente os desempenhos dos sistemas de lodo ativado e IFAS na remoção de matéria orgânica e nitrogênio de esgoto doméstico, associados à variação da idade do lodo com referência na biomassa suspensa.

O efeito da adição de suportes plásticos móveis em sistemas existentes de lodo ativado é avaliado como forma de subsidiar análises de viabilidade de emprego dessa solução para a ampliação e adaptação de estações de tratamento de esgotos domésticos.

A pesquisa foi desenvolvida em escala piloto, mantendo dois sistemas em funcionamento em paralelo, um representando um sistema de lodo ativado com remoção de nitrogênio e outro idêntico, exceto para a introdução dos suportes plásticos móveis. Desta forma, foi possível atribuir a diferença nos resultados à presença de biomassa aderida. Foram utilizados elementos suporte com área superficial específica de $300 \mathrm{~m}^{2} / \mathrm{m}^{3}$ e fração de enchimento de $50 \%$.

Ambos os sistemas foram mantidos em operação estável e eficiente, considerando a remoção de matéria orgânica. No entanto, o sistema IFAS teve melhor desempenho na remoção de nitrogênio em todas as fases experimentais, confirmando as vantagens antecipadas. Os resultados foram verificados em termos de taxas de aplicação previstas para cada porção de biomassa, de acordo com as idades do lodo estudadas.

Palavras-chave: Esgoto sanitário, Lodo ativado, Biofilme, MBBR, IFAS. 


\begin{abstract}
The activated sludge wastewater treatment process can be retrofitted to either receive larger organic loads or for nitrogen removal by introducing plastic media carriers, in a process known as IFAS - Integrated Fixed-Film Activated Sludge.

The project aims to comparatively assess the performances of activated sludge and IFAS systems in removing organic matter and nitrogen from domestic sewage, associated to the variation of the sludge age with reference to the suspended biomass.

The effect of adding plastic media carriers on existing activated sludge systems is evaluated as a subsidy for prefeasibility analysis of using this solution for the upgrading and retrofitting of municipal wastewater treatment plants.

The study was developed on a pilot scale, operating two systems in parallel, representing an activated sludge system with nitrogen removal and another identical system except for the introduction of plastic media carriers. Thus, it was possible to assign the difference in results to the presence of attached biomass. Carriers were used with $300 \mathrm{~m}^{2} / \mathrm{m}^{3}$ specific surface area and $50 \%$ filling fraction.

Both systems were kept under stable and efficient operation considering the removal of organic matter. However, the IFAS system had better performance at removing nitrogen in all experimental phases, confirming the anticipated advantages. The results were verified in terms of application rates expected for each portion of biomass in accordance with the sludge ages studied.
\end{abstract}

Keywords: Wastewater, Activated Sludge, Biofilm, MBBR, IFAS. 


\section{LISTA DE TABELAS}

Tabela 1 - Parâmetros típicos de projeto para um sistema IFAS. .44

Tabela 2 - Frações de remoção no biofilme recomendadas a $15^{\circ} \mathrm{C}$ .47

Tabela 3 - Dimensões básicas dos reatores biológicos. .56

Tabela 4 - Condições operacionais mantidas nos reatores .57

Tabela 5 - Vazões de alimentação das unidades piloto com o esgoto..... .58

Tabela 6 - Variáveis controladas nos afluentes e efluentes, pontos de amostragem e freqüências.

Tabela 7 - Variáveis controladas nos lodos, pontos de amostragem e freqüências..61 Tabela 8 - composição do esgoto afluente ao tratamento biológico. .66

Tabela 9 - Resultados da estatística descritiva dos resultados de DQO total e filtrada do afluente e dos efluentes dos processos de lodo ativado e MBBR - Fase 1

Tabela 10 - Resultados da estatística descritiva dos resultados de DQO total e filtrada do afluente e dos efluentes dos processos de lodo ativado e MBBR - Fase 2

Tabela 11 - Resultados da estatística descritiva dos resultados de DQO total e filtrada do afluente e dos efluentes dos processos de lodo ativado e MBBR - Fase 3

Tabela 12 - Resultados da estatística descritiva dos resultados de DBO total e filtrada do afluente e dos efluentes dos processos de lodo ativado e MBBR - Fase 1

Tabela 13 - Resultados da estatística descritiva dos resultados de DBO total e filtrada do afluente e dos efluentes dos processos de lodo ativado e MBBR - Fase 2

Tabela 14 - Resultados da estatística descritiva dos resultados de DBO total e filtrada do afluente e dos efluentes dos processos de lodo ativado e MBBR - Fase 3

Tabela 15 - Concentrações de sólidos em suspensão totais e voláteis no afluente e efluentes finais - Fase 1 
Tabela 16 - Concentrações de sólidos em suspensão totais e voláteis no afluente e efluentes finais - Fase 2

Tabela 17 - Concentrações de sólidos em suspensão totais e voláteis no afluente e efluentes finais - Fase 3

Tabela 18 - Resultados de $\mathrm{NKT}_{\text {e }} \mathrm{NH}_{3}-\mathrm{N}$ no afluente e efluentes finais - Fase $1 \ldots . .78$ Tabela 19 - Resultados de $\mathrm{NKT}$ e $\mathrm{NH}_{3}-\mathrm{N}$ no afluente e efluentes finais - Fase $2 \ldots . .78$ Tabela 20- Resultados de $\mathrm{NKT}_{\text {e }} \mathrm{NH}_{3}-\mathrm{N}$ no afluente e efluentes finais - Fase $3 \ldots . . .78$ Tabela 21 - Resultados de concentrações de nitrito nos efluentes dos processos de lodo ativado e MBBR - Fase 1

Tabela 22 - Resultados de concentrações de nitrito nos efluentes dos processos de lodo ativado e MBBR - Fase 2.

Tabela 23 - Resultados de concentrações de nitrito nos efluentes dos processos de lodo ativado e MBBR - Fase 3

Tabela 24 - Resultados de alcalinidade total no afluente e efluentes dos reatores Fase 1

Tabela 25 - Resultados de alcalinidade total no afluente e efluentes dos reatores Fase 2

Tabela 26 - Resultados de alcalinidade total no afluente e efluentes dos reatores Fase 3

Tabela 27 - Resultados de SSV e SST nos lodos dos tanques de aeração - Fase 1

Tabela 28 - Resultados de SSV e SST nos lodos dos tanques de aeração - Fase 2

Tabela 29 - Resultados de SSV e SST nos lodos dos tanques de aeração - Fase 3

Tabela 30 - Resultados da quantificação da biomassa aderida .93

Tabela 31 - Contribuições de SSV e SST da biomassa aderida .94

Tabela 32 - Quantidades relativas de biomassa no tanque de aeração - MBBR ....94

Tabela 33 - Resultados da Microscopia - MBBR . .95

Tabela 34 - Resultados da Microscopia - Lodo Ativado .96

Tabela 35 - Contribuições de SSV e SST da biomassa aderida .99 


\section{LISTA DE FIGURAS}

Figura 1 - Esquema de uma seção transversal do biofilme num filtro percolador (adaptado de (Metcalf \& Eddy, 2003)).

Figura 2 - Relação entre a carga de nitrogênio amoniacal e a taxa de nitrificação no experimento conduzido por Rusten et al. (1995)

Figura 3 - Relação entre taxa de nitrificação e concentração de oxigênio dissolvido em sistema com MBBR em escala piloto (Rusten et al, 1995)..... .38

Figura 4 - Fotografia de um detalhe de uma peneira cilíndrica. 40

Figura 5 - Agitação em reatores (a) aeróbios, (b) anóxicos e anaeróbios (ØDEGAARD et al. 1994).

Figura 6 - Configuração típica de sistema IFAS com suportes plásticos móveis......45

Figura 7 - Vista da estação elevatória de esgoto bruto. ..................................49

Figura 8 - Vista geral do tratamento preliminar..........................................49

Figura 9- Bomba de transferência de esgoto pré-tratado. .................................50

Figura 10 - Vista geral das unidades de tratamento. .....................................51

Figura 11 - Painel de interface da instrumentação. .....................................52

Figura 12 - Painel de controle dos equipamentos. ........................................52

Figura 13 - Analisador de oxigênio dissolvido. ............................................53

Figura 14 - Desenho esquemático dos sistemas em escala piloto.........................54

Figura 15 - Desenho esquemático dos reatores biológicos..................................55

Figura 16 - Desenho esquemático dos decantadores secundários........................56

Figura 17 - Fotografias documentando o procedimento experimental para quantificação e qualificação de biomassa aderida. ........................................62

Figura 18 - Série histórica - DQO total - Sistema 1: Lodo Ativado ........................69

Figura 19 - Série histórica - DQO total - Sistema 2: MBBR …...........................69

Figura 20 - Série histórica - DQO total - Eficiências ..................................... 70

Figura 21 - Diagramas Box-Whiskers - Resultados de DQO total - Fase 1 ...........70

Figura 22 - Diagramas Box-Whiskers - Resultados de DQO total - Fase 2 ...........71

Figura 23 - Diagramas Box-Whiskers - Resultados de DQO total - Fase 3 ...........71 
Figura 24 - Concentrações de sólidos em suspensão totais no afluente e efluentes Lodo Ativado

Figura 25 - Concentrações de sólidos em suspensão totais no afluente e efluentes MBBR .75

Figura 26 - Eficiências na remoção de sólidos em suspensão totais .75

Figura 27 - Diagramas Box-Whiskers - sólidos em suspensão totais - Fase 1 ........76

Figura 28 - Diagramas Box-Whiskers - sólidos em suspensão totais - Fase 2........76

Figura 29 - Diagramas Box-Whiskers - sólidos em suspensão totais - Fase 3 ........77

Figura 30 - Resultados de Nitrogênio Total Kjeldahl - Lodo ativado.........................79

Figura 31 - Resultados de Nitrogênio Total Kjeldahl - MBBR ………………….....79

Figura 32 - Diagramas Box-Whiskers - Nitrogênio Total Kjeldahl - Fase 1 .............80

Figura 33 - Diagramas Box-Whiskers - Nitrogênio Total Kjeldahl - Fase 2 ..............80

Figura 34 - Diagramas Box-Whiskers - Nitrogênio Total Kjeldahl - Fase 3..............80

Figura 35 - Resultados de Nitrogênio Amoniacal - Lodo ativado ..............................81

Figura 36 - Resultados de Nitrogênio Amoniacal - MBBR ……….........................81

Figura 37 - Diagramas Box-Whiskers - Nitrogênio Amoniacal - Fase 1 ..................82

Figura 38 - Diagramas Box-Whiskers - Nitrogênio Amoniacal - Fase 2 …................82

Figura 39 - Diagramas Box-Whiskers - Nitrogênio Amoniacal - Fase 3..................82

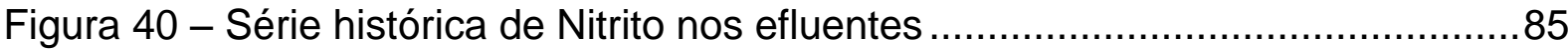

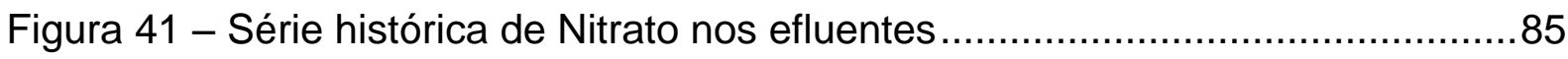

Figura 42 - Diagramas Box-Whiskers de concentração de nitrito nos efluentes - Fase 1

Figura 43 - Diagramas Box-Whiskers de concentração de nitrito nos efluentes - Fase 2 .86

Figura 44 - Diagramas Box-Whiskers de concentração de nitrito nos efluentes - Fase 3 .86

Figura 45 - Diagramas Box-Whiskers de concentração de nitrato nos efluentes Fase 1

Figura 46 - Diagramas Box-Whiskers de concentração de nitrato nos efluentes Fase 2 
Figura 47 - Diagramas Box-Whiskers de concentração de nitrato nos efluentes Fase 3

Figura 48 - Resultados de alcalinidade total no afluente e efluentes dos reatores Fase 1 89

Figura 49 - Resultados de alcalinidade total no afluente e efluentes dos reatores Fase 2 .89

Figura 50 - Resultados de alcalinidade total no afluente e efluentes dos reatores Fase 3 .90

Figura 51 - Séries históricas de concentração de SSV - Fase 1 ….......................92

Figura 52 - Monitoramento de temperatura nos tanques. .97

Figura 53 - Monitoramento de OD e pH por sensores instalados nos tanques - Lodo Ativado.

Figura 54 - Monitoramento de OD e pH por sensores instalados nos tanques MBBR. 98

Figura 55 - Série histórica calculada para a taxa de aplicação superficial de DQO referentes à fração de substrato calculada para a biomassa aderida. 100 Figura 56 - Série histórica calculada para a taxa de aplicação superficial de amônia referentes à fração de substrato calculada para a biomassa aderida. 100 Figura 57- Relação entre a carga de nitrogênio amoniacal e a taxa de nitrificação referentes à fração da biomassa aderida. 102 


\section{LISTA DE ABREVIATURAS E SIGLAS}

ABES Associação Brasileira de Engenharia Hidráulica e Sanitária

APHA American Public Health Association

ASCE American Society of Civil Engineers

AWWA American Water Works Association

EWRI Environmental \& Water Resources Institute

IFAS Integrated Fixed-Film Activated Sludge

IWA International Water Association

MBBR Moving Bed Biofilm Reactor

MTBL Mass Transfer Boundary Layer

UFRJ Universidade Federal do Rio de Janeiro

U.S. EPA U.S. Environmental Protection Agency

WEF Water Environment Federation 


\section{LISTA DE SÍMBOLOS}

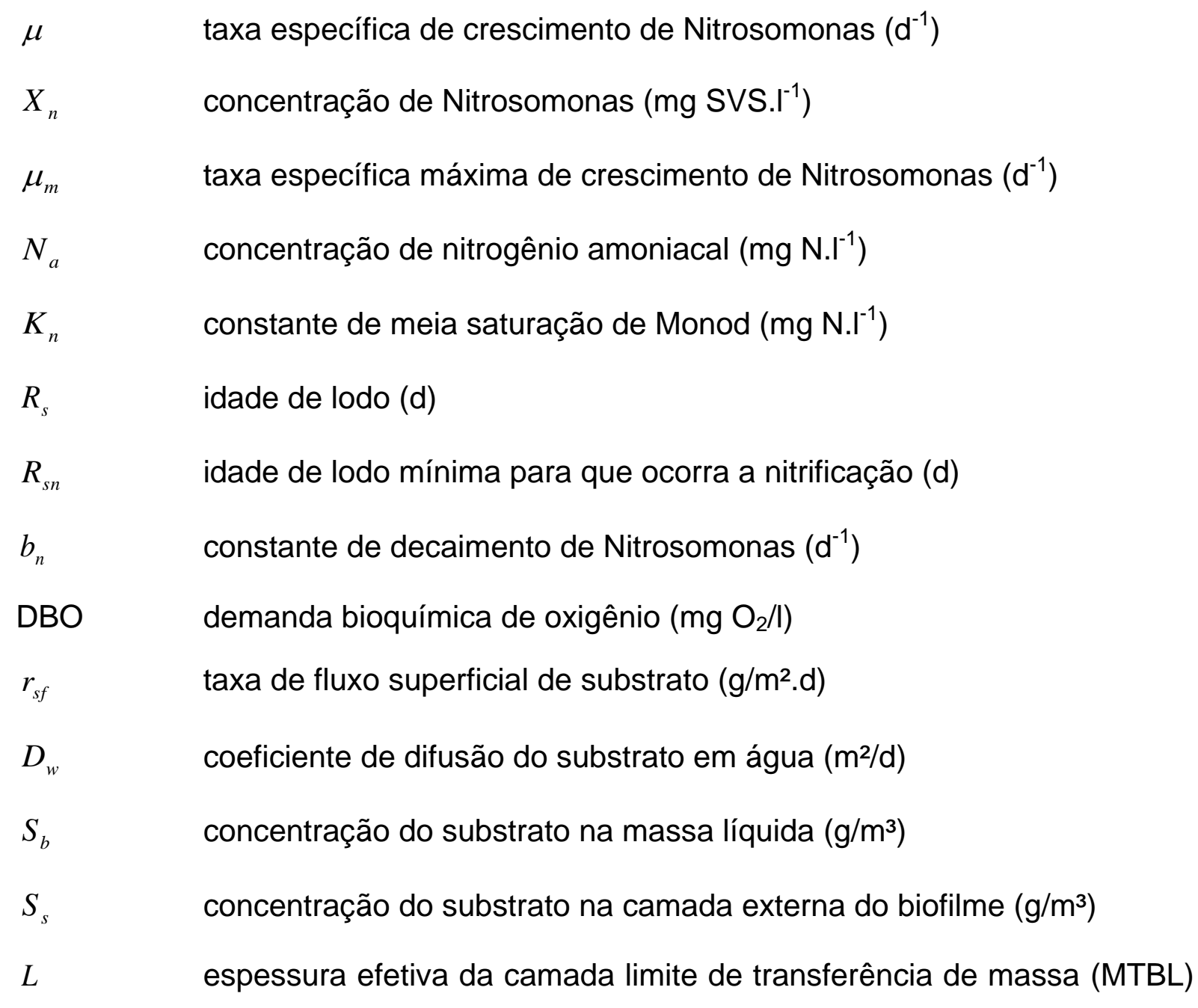

(m) 


\section{SUMÁRIO}

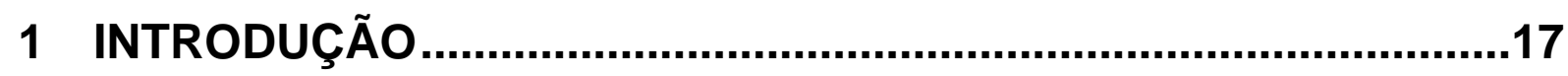

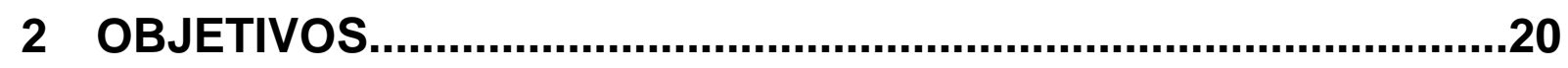

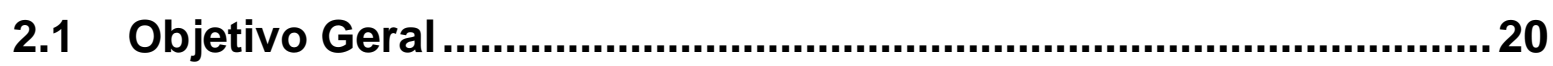

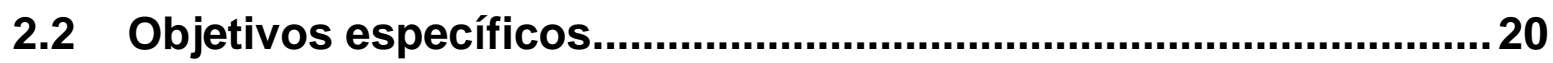

3 REVISÃo BIBLIOGRÁFICA .....................................................21

3.1 Remoção de Nitrogênio no Tratamento de Esgotos Sanitários ...21

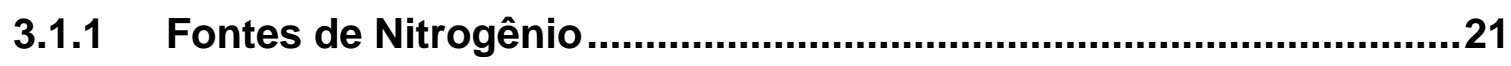

3.1.2 Efeitos dos nutrientes em corpos receptores..................................22

3.1.3 Princípios básicos da remoção de nitrogênio: ..................................23

3.1.4 Nitrificação Biológica ......................................................................24

3.1.5 Nitrificação em Reatores de Biomassa em Suspensão ...................27

3.1.6 Nitrificação em Reatores de Biomassa Aderida ...............................28

3.1.7 Desnitrificação Biológica .................................................................28

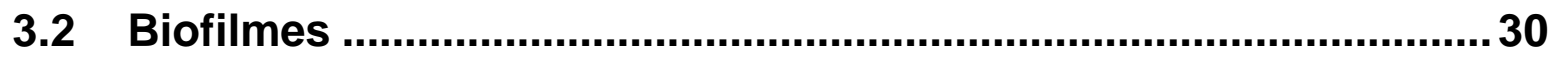

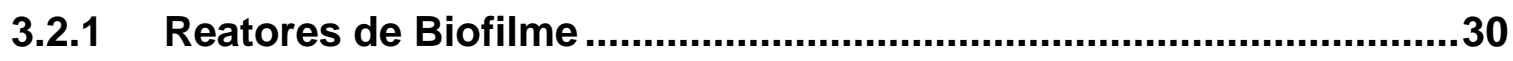

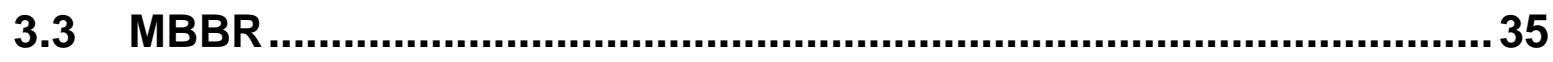

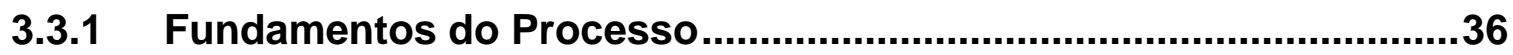

3.3.2 Orientações de Projeto .......................................................................

3.4 Reatores Híbridos............................................................................ 43

3.4.1 Considerações de Projeto .................................................................

4 MATERIAIS E MÉTODOS..........................................................48

4.1 Instalações das unidades experimentais.........................................48

4.2 Descrição das unidades de tratamento em escala piloto .............53

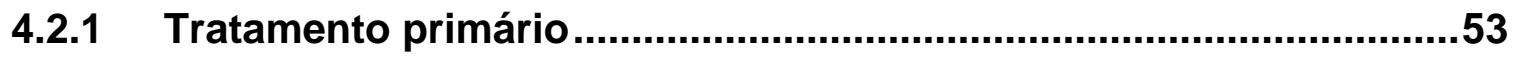




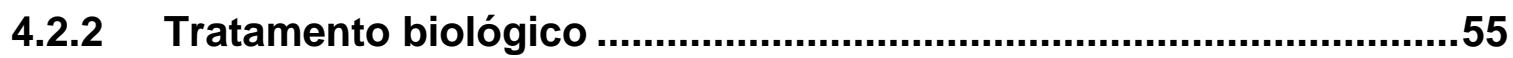

4.3 Descrição dos procedimentos operacionais ..................................56

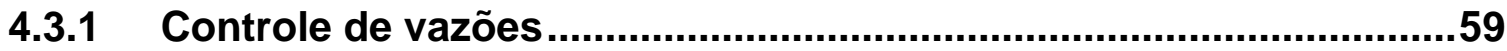

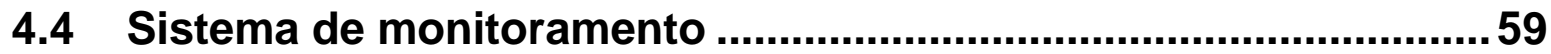

4.4.1 Determinação das Características do Afluente e dos Efluentes .....59

4.4.2 Determinação das Características dos Lodos dos Reatores Biológicos 60

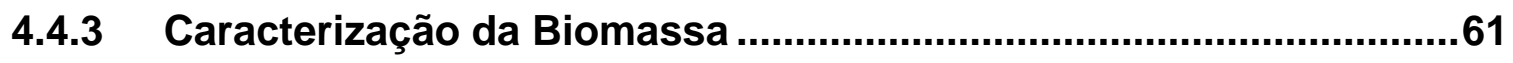

5 RESULTADOS E DISCUSSÕES ..............................................64

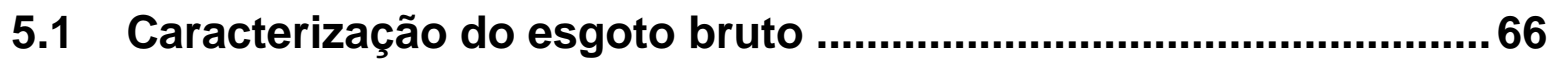

5.2 Apresentação dos resultados do monitoramento ..........................66

5.2.1 Resultados relativos à remoção de matéria orgânica e sólidos em suspensão .67

5.2.2 Resultados relativos à remoção de compostos nitrogenados .........77

5.2.3 Caracterização da Biomassa nos Reatores.......................................90

5.2.4 Monitoramento dos Lodos nos Reatores Mediante Sensores.........96

5.3 Verificação dos Parâmetros com Foco na Biomassa Aderida .....98

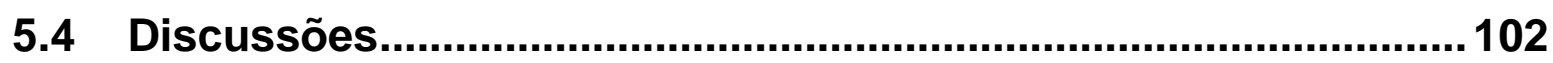

6 CONCLUSÕES E RECOMENDAÇÕES......................................105

7 REFERÊNCIAS BIBLIOGRÁFICAS ........................................107 


\section{INTRODUÇÃO}

Os avanços tecnológicos na área do tratamento de esgotos e a evolução da legislação federal que prevê a futura retomada do padrão de emissão para nitrogênio amoniacal, temporariamente suspenso, fazem com que seja necessária uma avaliação mais pormenorizada e atualizada das tecnologias disponíveis. O processo de lodo ativado é utilizado em larga escala na Região Metropolitana de São Paulo e em outros grandes centros urbanos. A transformação dos tanques de aeração em reatores híbridos, isto é, com biomassa em suspensão e aderida, pode ser feita pela introdução de suportes plásticos móveis, constituindo uma alternativa promissora para ampliar a capacidade de sistemas de lodo ativado na remoção de carga orgânica e, principalmente, de nitrogênio.

O processo de tratamento de esgotos sanitários com o uso de reatores de biofilme de leito móvel (MBBR - Moving Bed Biofilm Reactor) é baseado na utilização de biofilmes para a degradação de matéria orgânica e remoção de nutrientes, estabelecidos sobre a superfície oferecida por suportes plásticos móveis introduzidos nos reatores biológicos. Essa tecnologia permite o tratamento de efluentes com altas cargas, industriais ou domésticos, em plantas relativamente reduzidas. Sua utilização pode ser numa configuração híbrida com um sistema de lodos ativados, em que há recirculação dos sólidos (ØDEGAARD et al., 1993), de maneira que combine as vantagens dos sistemas de lodos ativados (biomassa em suspensão) e de sistemas com biofilme (biomassa aderida), usualmente denominada IFAS (Integrated Fixed-Film Activated Sludge).

A presente pesquisa tem por objetivo a avaliação da capacidade dos sistemas IFAS na remoção de matéria orgânica e nitrogênio, comparativamente ao processo de lodo ativado, tratando esgoto doméstico. $O$ efeito da adição de elementos suporte móveis em sistemas existentes de lodo ativado é avaliado como forma de subsidiar análises de viabilidade de emprego dessa solução para a ampliação e adaptação de estações de tratamento de esgotos domésticos, tendo como condições ambientais de contorno as temperaturas típicas da cidade de São Paulo e esgotos domésticos com concentrações semelhantes àquelas encontradas nos sistemas de esgotamento sanitário desse município. 
Especialmente na RMSP, os planos diretores de esgoto têm demonstrado que os espaços disponíveis para ampliação das estações não serão suficientes para garantir a degradação da matéria orgânica do esgoto e ao mesmo tempo remoção de nitrogênio e fósforo, mantendo-se a concepção atual de tratamento por lodo ativado convencional. Assim, tal agregação de benefícios deverá recorrer aos avanços tecnológicos e a opção do uso da tecnologia MBBR ora avaliada pode ser viável exatamente nessas situações em que há restrição de área.

A introdução de suportes plásticos móveis que propiciam considerável área superficial para desenvolvimento de biofilme se mostra como uma alternativa atraente no que se refere à possibilidade de ampliação da capacidade nominal da planta e de remoção de nitrogênio. Fabricantes recomendam a utilização de tais elementos numa faixa de variação que varia de $30 \%$ a $70 \%$ em volume dos reatores biológicos.

Biofilmes consistem em comunidades de microorganismos desenvolvidas sobre superfícies. No caso em questão os elementos de suporte são pequenas peças de polietileno, que apresentam extensa área superficial específica (300 a $500 \mathrm{~m}^{2} / \mathrm{m}^{3}$ ) e se encontram suspensas e em movimento no lodo do reator. A agitação é proporcionada pelo próprio sistema de aeração, constituído por difusores de ar instalados no fundo do tanque (HEM, 1994).

As substâncias consideradas poluentes, matéria orgânica e nitrogênio na forma amoniacal, são o substrato para o crescimento da massa bacteriana cuja concentração, se apresentando na forma de biofilme, é muito maior que se estivesse em suspensão simplesmente. A atividade microbiológica é mais alta, fato devido à grande variedade de populações, principalmente bacterianas, nos biofilmes (RUSTEN et al., 1994). Por esse motivo, a quantidade de substrato que pode ser removida é também maior.

Os biofilmes têm como característica importante a estabilidade a variações operacionais, sejam de carga, vazão, ou composição do esgoto afluente. Uma vez que as culturas estejam plenamente estabelecidas no meio suporte móvel, oferecem robustez ao sistema, resistindo a condições que o lodo em suspensão não seria capaz. Os níveis de nutrientes e de oxigênio dissolvido são as variáveis mais importantes de controle do sistema. A nitrificação também é beneficiada por esse efeito de estabilidade, na medida em que as bactérias nitrificantes também ficam 
instaladas nessas comunidades de forma que a oxidação da amônia ocorre com idades do lodo baixas, se calculadas em relação aos sólidos em suspensão.

O excesso de biofilme se desprende naturalmente do suporte, cedendo superfície para a ocupação de outros microorganismos, e os fragmentos liberados são facilmente separados da fase líquida em etapa seguinte, por serem mais compactos e consequentemente sedimentarem mais facilmente que os flocos do lodo convencional.

Essa tecnologia pode ser implantada em sistemas existentes de lodos ativados convencionais, para aumento da sua capacidade de remoção de matéria orgânica (LESSEL, 1993) ou transformação numa planta com capacidade de remoção de nitrogênio. Isso se consegue com a simples introdução dos elementos de suporte nos reatores biológicos. Conforme o objetivo buscado no tratamento, pode ser implementada pré ou pós desnitrificação, inclusive com a possibilidade de utilização no interior das câmaras anóxicas. A melhoria das estações ocorre por diversos aspectos, sejam eles o aumento da quantidade de microorganismos, a melhoria na transferência de oxigênio para a fase líquida, ou a facilitação da separação de sólidos, que muitas vezes é o ponto crítico de estações de tratamento de esgotos. 


\section{OBJETIVOS}

\subsection{Objetivo Geral}

O objetivo central do estudo é a produção de informações para subsidiar a análise da viabilidade do emprego do processo de lodo ativado convencional ou híbrido, sob a forma de reator biológico de leito móvel, para a remoção de matéria orgânica e nitrogênio de esgoto sanitário.

\subsection{Objetivos específicos}

- Identificação dos efeitos da introdução dos suportes plásticos móveis na remoção de matéria orgânica carbonácea e nitrogênio amoniacal;

- Avaliação do desempenho dos sistemas na remoção de matéria orgânica e nitrogênio de esgoto doméstico, associados à variação da idade do lodo com referência na biomassa suspensa;

- Quantificação de biomassa aderida em reator biológico de leito móvel e sua caracterização qualitativa. 


\section{REVISÃO BIBLIOGRÁFICA}

\subsection{Remoção de Nitrogênio no Tratamento de Esgotos Sanitários}

O tratamento terciário de esgotos sanitários que incorpora a remoção dos nutrientes nitrogênio e fósforo em complemento ao processo secundário que já objetiva a remoção de sólidos sedimentáveis e de material orgânico, é um requisito que deverá ser progressivamente exigido de plantas de tratamento de esgotos. Esses são talvez os componentes químicos mais significantes depois daqueles objetivados nos tratamentos primário e secundário a serem removidos dos esgotos domésticos antes de sua devolução ao meio ambiente.

\subsubsection{Fontes de Nitrogênio}

O nitrogênio é um elemento essencial para o crescimento e reprodução dos organismos vivos que ocorre naturalmente, sendo o componente mais abundante na atmosfera. Os compostos nitrogenados presentes nos esgotos sanitários têm origem associada a proteínas e ácidos nucleicos em cuja decomposição é produzida amônia, $\mathrm{Na}$ agricultura compostos nitrogenados comumente utilizados em fertilizantes são a uréia, fosfato de amônio, sulfato de amônio e nitrato de amônio (WEF, MOP No. 29, 2005).

As formas mais comuns de nitrogênio em águas residuárias são a amônia $\left(\mathrm{NH}_{3}\right)$, íon amônio $\left(\mathrm{NH}_{4}{ }^{+}\right)$, gás nitrogênio $\left(\mathrm{N}_{2}\right)$, nitrito $\left(\mathrm{NO}_{2}{ }^{-}\right)$, nitrato $\left(\mathrm{NO}_{3}{ }^{-}\right)$e nitrogênio orgânico. Esgotos domésticos contêm principalmente amônio e nitrogênio orgânico que consiste em uma mistura de compostos de amino $\left(\mathrm{NH}_{2}{ }^{-}\right)$, incluindo aminoácidos e proteínas e é convertido para amônio num processo de decomposição bacteriana chamado de amonificação. 


\subsubsection{Efeitos dos nutrientes em corpos receptores}

A acumulação excessiva de nutrientes em águas superficiais pode causar desequilíbrios ecológicos que afetam a vida aquática no primeiro momento e consequentemente de humanos e demais animais terrestres que com elas estabelecem relações. Podem ser elencados como principais efeitos associados a descargas de compostos nitrogenados em corpos receptores:

- Eutrofização - adição de nutrientes a um sistema aquático provocando crescimento excessivo de plantas e algas em corpos receptores. Como esses organismos morrem e se decompõem, a respiração excessiva pode reduzir a concentração de oxigênio dissolvido na água. O desenvolvimento de algas em águas pertencentes a mananciais também pode comprometer a disponibilidade hídrica para esse fim, além de efeitos ecológicos como a redução da biodiversidade e a invasão de novas espécies Em condições estuarinas é comumente o nutriente limitante para o desencadeamento da eutrofização.

- Toxicidade da amônia - a forma molecular ou não ionizada do nitrogênio amoniacal é tóxica para peixes e outras espécies aquáticas, com efeitos que podem ser agudos, representados pela mortalidade de peixes, ou crônicos, impondo consequências na reprodução ou demais aspectos da saúde dos organismos (U.S. EPA, 1993). Também representa demanda de oxigênio quando despejado num corpo d'água superficial, outro efeito negativo para a vida aquática;

- Nitrato em águas subterrâneas - a descarga de nitrato diretamente ou de amônia, que mais tarde é nitrificada, em águas subterrâneas ou mesmo em águas superficiais pode potencialmente provocar uma desordem sanguínea chamada methemoglobinemia, que acomete crianças, resultando em sufocamento (WEF, MOP No. 29, 2005). 


\subsubsection{Princípios básicos da remoção de nitrogênio:}

O nitrogênio é um nutriente essencial para todos os organismos, incluindo as bactérias heterotróficas que removem poluentes orgânicos de águas residuárias. Assim, uma parcela do nitrogênio é removida por assimilação no crescimento de novas células bacterianas, numa proporção de aproximadamente $12 \%$ em massa dos sólidos suspensos voláteis produzidos (Metcalf \& Eddy, 2003). Entretanto, grande parte desse montante retorna ao processo pelos sobrenadantes das atividades de manejo do lodo biológico ao longo da fase sólida das plantas de tratamento.

Uma remoção efetiva de nitrogênio se baseia em processos biológicos realizados por bactérias autotróficas que promovem reações que tem como objetivo final a produção de nitrogênio na forma gasosa que é liberada para a atmosfera.

Microorganismos autotróficos como Nitrosomonas e Nitrobacter oxidam nitrogênio amoniacal $\left(\mathrm{NH}_{3}-\mathrm{N}\right)$ para nitrogênio na forma de nitrato $\left(\mathrm{NO}_{3}-\mathrm{N}\right)$ na presença de oxigênio dissolvido e num intervalo de $\mathrm{pH}$ neutro a levemente alcalino num processo chamado de nitrificação.

As duas reações oxiredutoras básicas na nitrificação são:

$$
\begin{aligned}
& \mathrm{NH}_{4}^{+}+\mathrm{O}_{2} \text { (Nitrosomonas) } \rightarrow \mathrm{NO}_{2}^{-}+\mathrm{H}_{2} \mathrm{O}+2 \mathrm{H}^{+} \\
& \left.\mathrm{NO}_{2}^{-}+1 / 2 \mathrm{O}_{2} \text { (Nitrobacter }\right) \rightarrow \mathrm{NO}_{3}^{-}
\end{aligned}
$$

Estequiometricamente a massa de oxigênio requerida para a primeira e segunda reação é de, respectivamente, 3,43 e $1,14 \mathrm{mg} \mathrm{O} / \mathrm{mg} \mathrm{N}$. Ainda há um consumo de amônia para o metabolismo das bactérias nitrificantes, mas em termos práticos, a conversão de amônia a nitrato, expressos como $\mathrm{N}$ requer $4,57 \mathrm{mg} \mathrm{O} / \mathrm{mg} \mathrm{N}$ utilizado (Ekama et al. 1984).

Sob condições anóxicas (concentração de oxigênio dissolvido igual a zero, mas com presença de oxigênio na forma de nitrato), organismos heterotróficos podem utilizar nitrato como fonte de oxigênio e reduzem o íon nitrato a gás nitrogênio, em presença de compostos carbonáceos biodegradáveis como doadores de elétrons no processo comumente chamado de desnitrificação. 


\subsubsection{Nitrificação Biológica}

Processos biológicos de biomassa em suspensão e de biomassa aderida podem realizar a nitrificação. Como ocorre em ambiente aeróbio, na maioria das vezes em processos com biomassa em suspensão ocorre junto à remoção de matéria orgânica, no mesmo processo, comumente de modo não intencional, especialmente em locais de clima quente quando não se mantiverem tempos suficientemente curtos de detenção sólidos para remoção apenas de DBO. Em sistemas de biomassa aderida a maioria da matéria orgânica precisa ser removida antes que as bactérias nitrificantes possam se estabelecer porque as espécies heterotróficas possuem maiores taxas de crescimento e podem dominar a área superficial do biofilme. Nesses casos a nitrificação em reatores de biomassa aderida se realiza após a remoção da DBO carbonácea ou em sistemas específicos projetados separadamente (Metcalf \& Eddy, 2003).

Geralmente considera-se que o crescimento de ambas as espécies de bactérias mais comumente envolvidas no processo de nitrificação é limitado pela concentração de amônia. Apenas a nitritação, oxidação da amônia para nitrito, o primeiro passo do processo, é considerado de impotância para a cinética do processo, sabendo-se que a nitratação, a oxidação de nitrito para nitrato, ocorre muito rapidamente, considerada como instantânea (Van Haandel e Marais, 1999). Utilizando a equação de Monod pode ser descrito o crescimento da Nitrosomonas na oxidação de amônia para nitrito:

$$
\mu X_{n}=\frac{\mu_{m} X_{n} N_{a}}{\left(N_{a}+K_{n}\right)}
$$

$\mu \quad=$ taxa específica de crescimento de Nitrosomonas $\left(\mathrm{d}^{-1}\right)$

$X_{n} \quad=$ concentração de Nitrosomonas (mg SVS..$^{-1}$ )

$\mu_{m} \quad=$ taxa específica máxima de crescimento de Nitrosomonas $\left(\mathrm{d}^{-1}\right)$

$N_{a} \quad=$ concentração de nitrogênio amoniacal $\left(\mathrm{mg} \mathrm{N}^{-1}{ }^{-1}\right)$

$K_{n} \quad=$ constante de meia saturação de $\operatorname{Monod}\left(\mathrm{mg} \mathrm{N} .^{-1}\right)$ 
O valor de $\mu$ depende da concentração do substrato, de modo que atinge o valor de $\mu_{m}$ para uma concentração alta. A constante $K_{n}$ é chamada de meia saturação por corresponder a valor da concentração do substrato quando $\mu=1 / 2 . \mu_{m}$.

Tipicamente, o crescimento bacteriano das Nitrosomonas é de 10 a 20 vezes menor que o observado para bactérias heterotróficas. Assim o tempo de detenção de sólidos de um sistema de biomassa em suspensão voltado para a nitrificação deve ser muito maior que o necessário para a manutenção da população heterotrófica. Dessa maneira, o parâmetro operacional mais importante no sistema de lodo ativado é a idade do lodo $\left(R_{s}\right)$, que indica o tempo médio de permanência de lodo no sistema, calculado como a razão entre a massa de lodo presente no sistema e a massa descartada diariamente (Van Haandel e Marais, 1999).

A idade do lodo em sistemas em que se pretende que ocorra a nitrificação deve ser numericamente maior que a idade de lodo mínima, caso contrário a reação não se desenvolve pela ausência das bactérias nitritantes.

$$
R_{s n}=\frac{1}{\left(\mu_{m}-b_{n}\right)}
$$

$R_{s n} \quad=$ idade de lodo mínima para que ocorra a nitrificação (d)

$b_{n} \quad=$ constante de decaimento de Nitrosomonas $\left(\mathrm{d}^{-1}\right)$

Quando em regime permanente, a quantidade de bactérias nitrificantes que deixarem o sistema será igual à quantidade produzida.

O crescimento da biomassa de nitrificantes é afetado por fatores ambientais e por consequência influenciam a idade de lodo mínima para nitrificação. Os mais importantes são a temperatura do esgoto, a concentração de oxigênio dissolvido, o $\mathrm{pH}$ e a alcalinidade e fatores inibidores.

A nitrificação pode ocorrer em temperaturas que variam de 4 a $45^{\circ} \mathrm{C}$, sendo que 0 intervalo ótimo para a taxa de crescimento é de 35 a $42{ }^{\circ} \mathrm{C}$ (U.S. EPA, 1993). De acordo com Van Haandel e Marais (1999), a equação simplificada de Arrehnius apresentada a seguir é frequentemente utilizada para a quantificação da influência da temperatura. $O$ coeficiente $\theta$ de dependência de Arrehnius varia de 1,11 a 1,13.

$$
\mu_{m t}=\mu_{m 20} \cdot \theta^{t-20}
$$


$\mu_{m t}=$ taxa específica máxima de crescimento de Nitrosomonas a uma temperatura $t\left(d^{-1}\right)$

$\mu_{m 20}=$ taxa específica máxima de crescimento de Nitrosomonas a $20^{\circ} \mathrm{C}\left(\mathrm{d}^{-1}\right)$

$\theta \quad=$ coeficiente de dependência de Arrehnius

As bactérias nitrificantes realizam seu metabolismo apenas sob condições aeróbias, de modo que as concentrações de oxigênio dissolvido na massa líquida exercem efeito importante sobre suas taxas de crescimento. $O$ valor da concentração que limita a taxa de nitrificação varia dependendo de diversas variáveis como a temperatura, carga orgânica, idade do lodo, e limitações da difusão. Pode-se dizer que a nitrificação não é limitada quando se praticam concentrações maiores que 2,0 $\mathrm{mg} / \mathrm{L}$ (WEF, MOP No. 29, 2005), mas a literatura tem publicado valores entre 0,3 e 2,0 mg OD/L (Van Haandel e Marais, 1999).

As reações de nitrificação são muito sensíveis ao $\mathrm{pH}$ e suas taxas diminuem consideravelmente quando da ocorrência de valores menores que 6,8 (Metcalf \& Eddy, 2003). Amplas variações do pH podem ser prejudiciais ao desempenho da nitrificação, mas uma performance satisfatória pode ser obtida com a manutenção do pH no intervalo de 6,5 a 8,0. Para se obter taxas ótimas de nitrificação é necessário buscar a faixa de 7,5 a 8,0 de valores do $\mathrm{pH}$. Os valores recomendados de alcalinidade são de 50 mg/L como mínimo e preferencialmente de 100 mg/L.

Uma grande variedade de substâncias orgânicas e inorgânicas pode inibir a nitrificação em concentrações muito menores que aquelas que afetariam organismos heterotróficos aeróbios. Compostos orgânicos inibidores podem incluir solventes químicos orgânicos, amina, proteínas, taninos, compostos fenólicos, álcoois, cianetos, éteres, carbamatos e benzeno (Metcalf \& Eddy, 2003). Esse efeito ocorre com maior intensidade quando as concentrações dessas substâncias variam muito. Quando as taxas de aplicação são menores e mais regulares os efeitos são menores (WEF, MOP No. 29, 2005). Metais pesados como níquel, cromo e cobre também podem inibir completamente a oxidação da amônia em concentrações de 0,25 mg/L, $0,25 \mathrm{mg} / \mathrm{L}$ e $0,10 \mathrm{mg} / \mathrm{L}$ respectivamente. Adicionalmente a amônia não ionizada $\left(\mathrm{NH}_{3}\right)$ e o ácido nitroso não ionizado $\left(\mathrm{NH}_{2}\right)$ podem ser inibidores para o metabolismo das Nitrosomonas e Nitrobacter dependendo das condições de temperatura e pH no reator. 


\subsubsection{Nitrificação em Reatores de Biomassa em Suspensão}

Em sistemas de tratamento biológico de biomassa em suspensão é possível controlar a quantidade de biomassa no processo e, portanto, a taxa de crescimento líquido de biomassa. O controle da taxa de crescimento global da biomassa é necessário para ajustar o sistema no sentido de alcançar os valores de crescimento desejados para ambos os grupos de bactérias, heterotróficas e autotróficas, que são concorrentes em relação a diversas variáveis que limitam a flexibilidade operacional, tais como:

- Dimensões físicas do sistema, especialmente do tanque de aeração, que determinam o tempo de detenção e a concentração da biomassa;

- Capacidade do sistema de aeração;

- Área superficial dos decantadores secundários que influencia as taxas limite de aplicação hidráulica e de sólidos sobre essas unidades; e

- Capacidade de bombeamento do retorno de lodo ativado, que restringe a taxa de recirculação de lodo ativado.

As diversas configurações de reatores para obtenção da nitrificação devem ser projetadas segundo dois parâmetros principais de projeto. O primeiro é a manutenção do tempo médio de permanência das bactérias nitrificantes no sistema suficiente para 0 estabelecimento da população de nitrificantes. Para o dimensionamento dos sistemas deve ser utilizada a idade de lodo referente ao volume da parcela aeróbia dos reatores $\left(\mathrm{R}_{\mathrm{s}}\right.$ aeróbico). Considera-se que a taxa de crescimento de nitrificantes é insignificante em condições de concentração de oxigênio dissolvido muito baixa ou zero. O segundo principal parâmetro consiste no tempo de detenção hidráulico que deve possibilitar que a biomassa reaja com a quantidade de amônia suficiente para cumprimento das necessidades de lançamento (WEF, MOP No. 29, 2005). 


\subsubsection{Nitrificação em Reatores de Biomassa Aderida}

Diferentemente dos sistemas de biomassa em suspensão, nos sistemas de biomassa exclusivamente aderida o estabelecimento e acumulação de bactérias autotróficas é limitado pelo crescimento das bactérias heterotróficas que são predominantes até que o substrato (material carbonáceo) seja consumido na sua maior parte. Dessa forma, as bactérias nitrificantes não constituirão uma parcela significativa na superfície do biofilme se a DBO solúvel apresentar valores ainda elevados. Um valor orientativo para que isso ocorra é de $15 \mathrm{mg} / \mathrm{L}$ de $\mathrm{DBO}_{5,20}$ como limite máximo (WEF, MOP No. 29, 2005).

Numa análise da distribuição espacial do biofilme em sistemas como o filtro percolador e o reator biológico rotativo de contato (Bio disco), por exemplo, a presença de nitrificantes é maior na porção final do reator, quando a biomassa heterotrófica já oxidou a matéria orgânica e a competição por área superficial e por oxigênio é reduzida.

O desempenho real de um sistema em particular depende do tipo e quantidade de meio suporte, características dos efluentes, e outros fatores ambientais já discutidos. A influência da difusão no transporte de massa é outra diferença fundamental entre sistemas de biomassa em suspensão e aderida. O substrato solúvel precisa alcançar as bactérias para ser utilizado. Nos reatores de biomassa em suspensão os microorganismos estão dispersos em flocos na massa líquida que contém o substrato e aceptores de elétrons e podem interagir com ela sem impedimentos físicos. A relação entre a superfície de contato com a massa líquida e a quantidade de microorganismos é muito menor nos biofilmes em função da alta concentração microbiana. A difusão dos líquidos e gases que envolvem o biofilme para o seu interior é muito dependente da concentração desses no limite da camada líquida e das taxas de remoção dos poluentes.

\subsubsection{Desnitrificação Biológica}

Como parte de remoção biológica de nitrogênio, a desnitrificação consiste na redução biológica de nitrato a óxido nítrico, óxido nitroso e finalmente a gás 
nitrogênio (Metcalf \& Eddy, 2003). Desconsiderando a assimilação do nitrato que envolve a sua redução para amônia para utilização na síntese celular, a outra modalidade de remoção de nitrato que ocorre e que é de maior interesse para a remoção de nitrogênio é a desnitrificação biológica, em que o nitrito ou o nitrato são utilizados como aceptores de elétrons para a oxidação de matéria orgânica ou inorgânica doadora de elétrons.

A um ambiente biológico com pouco ou nenhum oxigênio dissolvido, mas com a presença de nitrito ou nitrato, se refere como anóxico. A configuração mais comum do processo, conhecida como desnitrificação pré-anóxica, consiste num tanque anóxico seguido pelo tanque de aeração, onde ocorre a nitrificação, tendo o nitrato neste produzido, recirculado de volta para o tanque anóxico, onde o substrato orgânico do esgoto afluente fornece os doadores de elétrons necessários.

Bactérias heterotróficas e autotróficas de grande variedade podem ser capazes de realizar a desnitrificação, a maioria delas é facultativa quanto à utilização de oxigênio, nitrito ou nitrato, utilizando como substrato compostos orgânicos que incluem hidrogênio, metanol, carboidratos, ácidos orgânicos, alcoóis, benzoatos e outros compostos aromáticos (Metcalf \& Eddy, 2003). Muitos desses organismos também são comumente encontrados em sistemas que não foram projetados para a remoção de nitrogênio.

A equação estequiométrica para desnitrificação utilizando matéria orgânica biodegradável do esgoto é a seguinte:

$$
10 \mathrm{NO}_{3}+\mathrm{C}_{10} \mathrm{H}_{19} \mathrm{O}_{3} \mathrm{~N} \rightarrow 5 \mathrm{~N}_{2}+10 \mathrm{CO}_{2}+3 \mathrm{H}_{2} \mathrm{O}+\mathrm{NH}_{3}+10 \mathrm{OH}^{-}
$$

Além de fornecer energia para a redução de nitrato, a matéria orgânica carbonácea também é utilizada para a criação de nova biomassa.

A desnitrificação utiliza, inicialmente, o material rapidamente biodegradável e depois, o material lentamente biodegradável (Jordão e Pessoa, 2009). A taxa de desnitrificação é relacionada ao crescimento das bactérias que utilizam nitrito como aceptores de elétrons e pode ser influenciada por diversos fatores relacionados às características do esgoto afluente, configuração do processo e aspectos operacionais. 


\subsection{Biofilmes}

Diferentemente de reatores de biomassa em suspensão, como processos de lodo ativado, em que o acúmulo de microorganismos utilizados para a metabolização das substâncias poluentes é obtido através de retorno de biomassa retida nas unidades de separação de sólidos, reatores de biofilme retêm as células bacterianas na quantidade desejada para o processo num biofilme aderido a suportes fixos ou móveis. O biofilme é constituído por uma matriz que compreende diversos elementos como água e uma variedade de componentes solúveis e particulados que incluem produtos microbianos solúveis, material inerte e substâncias poliméricas extracelulares (EPS) (WEF, MOP No. 8, 2009).

O fenômeno da lavagem, que consiste na perda de grupos bacterianos específicos quando não são mantidas idades do lodo suficientes em reatores de biomassa em suspensão para a manutenção das quantidades desejadas de bactérias de crescimento lento ou sensíveis à temperatura, não ocorre normalmente em reatores de biofilme. Nesses sistemas esses grupos de bactérias ficam aderidos ao meio suporte, juntamente com as demais e, portanto, permanecem protegidas. Entretanto o efeito estabilizador do biofilme também pode não ocorrer de modo permanente, ou seja, se houver o destacamento do biofilme ou se as bactérias não estiverem localizadas onde possam receber as quantidades necessárias de substrato.

Os organismos responsáveis pelas reações bioquímicas em reatores de biomassa suspensa e aderida são os mesmos. Estão também sujeitos aos mesmos efeitos das condições do ambiente em que se localizam, ou seja, temperatura, $\mathrm{pH}$, doadores e aceptores de elétrons, e disponibilidade de macronutrientes (Morgenroth, 2008).

\subsubsection{Reatores de Biofilme}

O desempenho dos processos com biomassa aderida é geralmente limitado pela difusão, em contraponto ao tratamento por lodo ativado. As reações de remoção de substrato e de utilização dos doadores de elétrons ocorrem dentro da camada de biofilme, de maneira que as concentrações dos compostos envolvidos nas reações variam ao longo de sua espessura (Metcalf \& Eddy, 2003). 
O ambiente local dos biofilmes é determinado por cinco componentes:

- Superfície do meio suporte, também chamado de substratum;

- Biofilme (incluindo as frações particulada e líquida);

- Camada limite de transferência de massa (MTBL);

- Massa líquida; e

- Fase gasosa, quando significante.

A seguir são apresentados os principais aspectos de reatores de biofilme e de seus componentes.

\subsubsection{Caracterização dos Biofilmes}

Os reatores de biofilme são caracterizados em geral por dois processos, a transferência de massa e a conversão bioquímica, que influenciam a sua estrutura e função ne medida em que ocorrem em intensidades variadas dependentes das circunstâncias em que estão inseridos e afetam a composição e espessura do biofilme. O transporte de massa no interior do biofilme, que é a diferença mecanística básica entre reatores de biomassa aderida e em suspensão, é controlado pela difusão molecular. Os sistemas de biomassa em suspensão são limitados pela cinética como uma função da quantidade de biomassa, enquanto sistemas de biofilme são limitados pela difusão, representados pela área superficial. É necessário entender as interações entre os dois processos para a avaliação completa desses sistemas. Quando a transferência de massa é lenta, se comparada às reações de conversão bioquímica, deverão ocorrer grandes gradientes de concentração dos substratos dentro da MTBL e no interior do biofilme. Como resultado podem ser observadas zonas inativas nas regiões mais internas do biofilme que provocam implicações no projeto e operação dos reatores e na ecologia microbiana (WEF, MOP No. 8, 2009).

Outro equilíbrio deve ser estabelecido em relação à localização das bactérias no biofilme sob o ponto de vista da competição microbiana, baseada nas concentrações locais de substrato e nas condições de proteção mecânica pela massa do biofilme. Quando localizadas próximo à superfície as bactérias têm a disponibilidade de altas concentrações de substrato, mas ficam sujeitas a destacamentos induzidos por 
raspagem e abrasão. Os indivíduos que se instalam próximo ao substratum dispõem de maior proteção contra destacamento, mas ficam submetidos a reduzida disponibilidade de substratos (WEF, MOP No. 8, 2009).

Em situações em que ocorrem altas concentrações de substrato na massa líquida incluem-se aceptores de elétrons como o oxigênio dissolvido - ou baixas taxas de degradação, os substratos podem penetrar inteiramente nos biofilmes. Outro fator que pode causar a penetração total dos substratos, mesmo em sistema que tipicamente operam em condições que resultam em biofilmes limitados pela transferência de massa, é o destacamento descontínuo que pode ser hidraulicamente provocado, induzido por carga orgânica de choque ou por colisão entre meio suporte.

O desempenho do reator de biofilme, em termos práticos, é dependente da área superficial. A espessura aumentada em função da penetração parcial de substrato não aumenta a capacidade de remoção de substrato. Gradientes de concentração de oxigênio dissolvido dentro do biofilme permitem o estabelecimento de diferentes zonas de oxirredução, e a penetração parcial pode resultar em biofilmes apresentando zonas aeróbicas, anóxicas e anaeróbias simultaneamente. Esse efeito pode ser benéfico na medida em que possibilita a consideração da nitrificação e desnitrificação ocorrendo continuamente no biofilme como possível solução de projeto, eliminando a necessidade de reatores exclusivamente anóxicos.

O intervalo de espessuras resultantes em sistemas de biofilme se dá como resultado do equilíbrio entre o crescimento bacteriano e o destacamento de porções da matriz de biomassa aderida. A espessura excessiva do biofilme deve ser evitada por trazer dois efeitos prejudiciais a reatores de escala real. Primeiro, pode reduzir a área superficial por um encobrimento tão intenso da superfície do meio suporte que elimine detalhes de sua geometria, destinados a lhe conferir maior área superficial. O segundo é a possibilidade de impedir o aporte de doadores e aceptores de elétrons ou macronutrientes à biomassa próxima ao meio suporte. Com isso podem ser criadas condições anaeróbias no interior da biomassa e como conseqüência podem ser produzidos maus odores ou um destacamento descontrolado de segmentos de biofilme com dimensões equivalentes às sua espessura, efeito também chamado de descamação (WEF, MOP No. 8, 2009). Os mecanismos de controle de espessura de biofilme podem ser classificados como passivos e ativos, 
ou dedicados e são induzidos mecanicamente. Os mecanismos passivos advêm das próprias condições operacionais normais dos reatores. Um exemplo são as contínuas colisões entre elementos suporte resultantes da mistura em um MBBR. Mecanismos dedicados requerem ciclos operacionais com função específica como a retro lavagem de um filtro biológico submerso ou a lavagem de um filtro percolador.

O desenvolvimento dos biofilmes é afetado por diversos fatores como (1) as condições de concentrações de substrato, temperatura e pH da fase líquida, (2) a intensidade das resistências à transferência de massa externas e internas ao biofilme, (3) a cinética das reações bioquímicas no seu interior, e (4) o destacamento. O seu destacamento pode, igualmente, ocorrer de formas diversas, sejam elas a abrasão, provocada pela colisão de partículas, a erosão provocada por esforços de cisalhamento hidraulicamente impostos, a descamação que é o resultado de deficiência na aderência com o meio suporte e a predação exercida por espécies maiores de micro fauna.

O crescimento e cinética da utilização dos substratos, que num sistema de biomassa em suspensão acontecem na massa líquida, em sistema de biomassa aderida ocorrem dentro do biofilme. As condições de crescimento e hidrodinâmica do sistema podem alterar sua espessura. A massa líquida pode escoar por sobre a superfície do biofilme ou estar misturada em torno de um meio suporte submerso e é separada do biofilme por uma camada líquida estagnada, também chamada de camada de difusão ou MTBL, por onde são transportados os elementos necessários para as reações de metabolismo celular e, no sentido contrário, são enviados para a massa líquida os produtos dessas reações (Metcalf \& Eddy, 2003).

A taxa de transferência de massa através da MTBL é chamada de fluxo superficial e é dado pela equação (7)

$$
r_{s f}=-D_{w} \frac{\left(S_{b}-S_{s}\right)}{L}
$$

$r_{s f} \quad=$ taxa de fluxo superficial de substrato $\left(\mathrm{g} / \mathrm{m}^{2} . \mathrm{d}\right)$

$D_{w} \quad=$ coeficiente de difusão do substrato em água $\left(\mathrm{m}^{2} / \mathrm{d}\right)$

$S_{b} \quad=$ concentração do substrato na massa líquida $\left(\mathrm{g} / \mathrm{m}^{3}\right)$

$S_{s} \quad=$ concentração do substrato na camada externa do biofilme $\left(\mathrm{g} / \mathrm{m}^{3}\right)$

$L=$ = espessura efetiva da camada limite de transferência de massa (MTBL) (m) 
A Figura 1 ilustra a estrutura do biofilme e indica os principais fluxos pertinentes ao processo.

\subsubsection{Hidrodinâmica dos Reatores}

Um componente de projeto que constitui uma diferença chave entre diferentes tipos de reatores de biofilme são as condições de mistura e hidrodinâmica da massa líquida dos reatores. A resistência à transferência de massa externa ao biofilme reduz o fluxo para o interior do biofilme e, de acordo com HEM (1994), na nitrificação em MBBR esse é o processo que controla a taxa de reação.

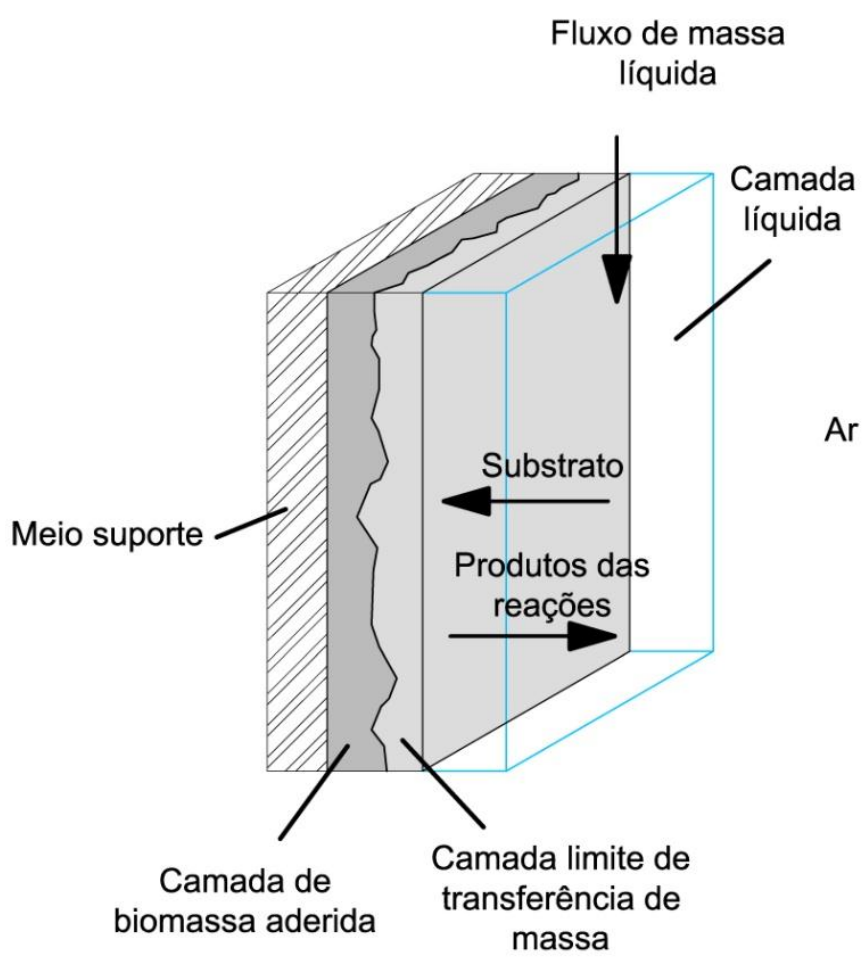

Figura 1 - Esquema de uma seção transversal do biofilme num filtro percolador (adaptado de (Metcalf \& Eddy, 2003)).

Em sistemas como filtros percoladores a hidrodinâmica é complexa, tornando difícil a modelagem matemática do processo. Como a hidrodinâmica de uma massa líquida é relativamente mais simples, como sistemas de mistura completa, podem ser utilizados princípios mecanísticos no projeto de reatores de biofilme com essa natureza. O estudo é influenciado pelas características (1) físicas dos tanques e 
meio suporte, como entradas e saídas do efluente, sistema de mistura e de aeração, e (2) operacionais que variam entre fluxo contínuo ou batelada, e a necessidade de retrolavagem periódica (Grady et al. 1999). O desenvolvimento e controle do biofilme, bem como a carga superficial aplicada - considerando a influência sobre a intensidade da resistência à transferência de massa externa ao biofilme e distribuição dessa carga sobre a área disponível - influenciam o projeto do reator de biofilme. São aspectos de interesse a mistura da massa líquida, a MTBL e os processos bioquímicos (WEF, MOP No. 8, 2009).

Quanto maior a turbulência e as tensões de cisalhamento do ambiente, maior a planicidade e densidade do biofilme, que, nesses casos, tem um melhor desempenho em relação à difusividade se comparados com filmes rugosos e pouco densos característicos de ambientes calmos com baixa abrasão.

\subsection{MBBR}

Um reator de biofilme de leito móvel (MBBR) utiliza elementos plásticos de suporte de baixa densidade imersos na massa líquida para crescimento de biomassa, mantidos no reator pelo uso de grades ou peneiras. Pode ser aplicado tanto em ambiente aeróbio quanto anóxico, sendo a agitação dos reatores obtida, em tanques aeróbios, pelo sistema de aeração difusa utilizada para o fornecimento de ar para o processo, e as unidades anóxicas misturadas com misturadores submersíveis de baixa velocidade. Um MBBR não depende de recirculação de biomassa em suspensão para alcançar os objetivos de tratamento. A quantidade de biomassa aderida aos suportes móveis já deve ser suficiente para a degradação dos compostos poluentes desejados. Uma versão modificada do processo é um sistema do tipo híbrido, que combina o tratamento por lodo ativado com elementos suporte plásticos num sistema integrado de lodo ativado e biomassa aderida (IFAS Integrated Fixed-Film Activated Sludge System) (WEF, MOP No. 29, 2005).

Os elementos suporte utilizados num MBBR são construídos em polietileno e têm uma densidade específica levemente menor que 1,0. Os elementos comumente têm o formato de pequenos cilindros com aletas em cruz no interior para aumento da superfície específica. Para fins de projeto, a área superficial dos elementos plásticos 
a ser considerada despreza a superfície externa, sujeita a choques e maior erosão sobre o biofilme, adotando apenas a área das faces internas protegidas, chamada de área superficial específica.

\subsubsection{Fundamentos do Processo}

Sistemas MBBR podem ser utilizados para tratamento de esgotos domésticos ou de efluentes industriais. Além dos reatores de biofilme submerso, também necessitam de uma unidade de separação final de sólidos, apesar de não necessitarem do retorno da biomassa para manutenção da quantidade de microorganismos requerida pelo processo. As primeiras plantas instaladas na Noruega ainda não apresentam sinais de desgaste dos suportes plásticos em mais de 15 anos de operação contínua (WEF, MOP No. 8, 2009).

Como vantagens de reatores de biofilme de leito móvel em comparação com sistemas de lodo ativado ou sistemas de biomassa aderida de leito fixo podem ser relacionadas:

- Menor volume dos reatores biológicos se comparado com o sistema de lodo ativado conjugado com as unidades de separação de sólidos, sejam decantadores secundários ou sistemas de membranas para alcançar os mesmos objetivos de tratamento;

- As taxas de aplicação de sólidos para as unidades de separação de sólidos são significantemente reduzidas quando comparadas às de sistemas de lodo ativado;

- Não há necessidade de operações de retro lavagem para controle da espessura de biofilme ou desentupimento do meio suporte por se tratar de reatores de mistura completa e fluxo contínuo;

- Apresentam a flexibilidade de sistemas de lodo ativado para manobras no fluxograma de processo para alcance de objetivos específicos de tratamento sem a necessidade de bombeamento de retorno de lodo;

- É uma alternativa com reduzida quantidade de intervenções para a adequação de plantas existentes de tratamento de esgotos domésticos. 
As pesquisas que fundamentaram 0 desenvolvimento da tecnologia MBBR resultaram de um acordo político entre países do norte europeu para obter reduções significativas em aproximadamente $50 \%$ na descarga de nutrientes para o Mar do Norte de 1985 a 1995 (Hem et al., 1994).

Rusten et al. (1995) desenvolveram pesquisa com MBBR em sistema com reatores em série envolvendo pré-desnitrificação por meio de recirculação interna. $O$ esgoto utilizado na pesquisa, desenvolvida na Noruega, demonstrou-se diluído e de baixa alcalinidade, recebendo anteriormente apenas tratamento preliminar. A temperatura ambiente era inferior a $10^{\circ} \mathrm{C}$. Um dos resultados mais importantes foi o corelacionamento entre a carga de nitrogênio amoniacal aplicada e a taxa de nitrificação, reproduzida na Figura 2.

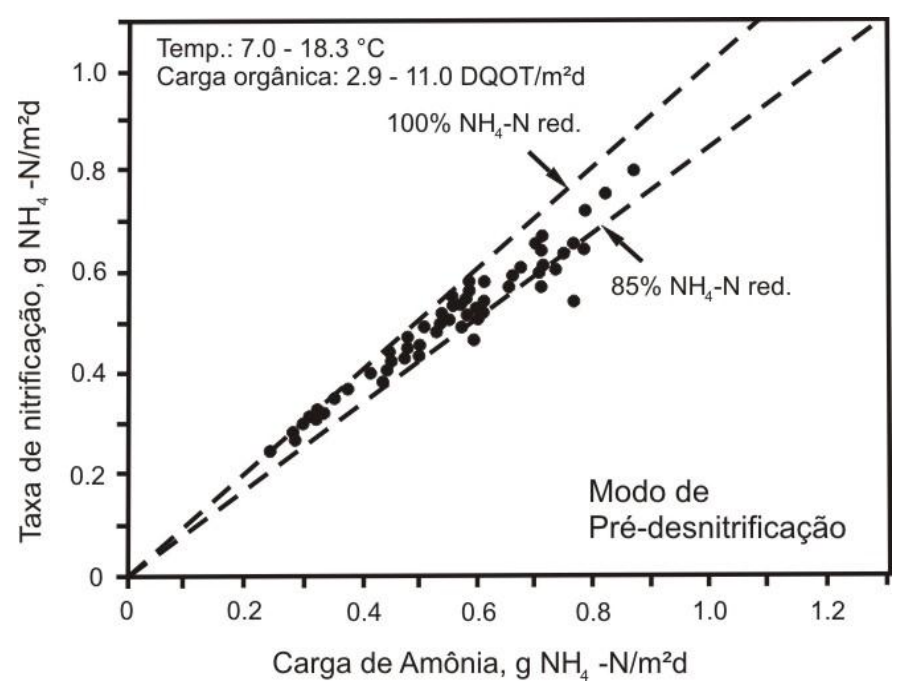

Figura 2 - Relação entre a carga de nitrogênio amoniacal e a taxa de nitrificação no experimento conduzido por Rusten et al. (1995)

Pode-se observar taxas elevadas de conversão de $\mathrm{N}^{-\mathrm{NH}_{4}}$ obtidas sob taxa de aplicação de até $0,9 \mathrm{~g} \mathrm{~N}-\mathrm{NH}_{4} / \mathrm{m}^{2}$.d. Constatou-se também que taxas de aplicação de até $11 \mathrm{~g} \mathrm{DQO} / \mathrm{m}^{2} . \mathrm{d}$ não interferiram na nitrificação, principalmente por que boa parte dela foi consumida na câmara anóxica.

Outra condição de suma importância para o desenvolvimento do processo com MBBR é a concentração de oxigênio dissolvido a ser mantida nos tanques de aeração. Nos estudos desenvolvidos pelo mesmo grupo de pesquisadores noruegueses, principais responsáveis pela evolução dessa tecnologia, foi obtida a co-relação entre taxa de nitrificação e concentração de oxigênio dissolvido reproduzida na Figura 3. 
Inferiu-se que a camada líquida à superfície do biofilme formado nos corpos móveis é limitante para a transferência de oxigênio. Como o oxigênio dissolvido é consumido para degradação de matéria orgânica por microrganismos heterotróficos, que se posicionam na parte externa do biofilme, para obtenção da nitrificação o nível de oxigênio dissolvido deve ser elevado para que haja penetração nas camadas internas, região em que predominam as bactérias nitrificantes. Nesta Figura 3, observa-se uma relação linear entre a concentração de oxigênio dissolvido e a taxa de nitrificação. A reta deve interceptar o eixo das abscissas entre 2,5 e 3,0 mg $\mathrm{O}_{2} / \mathrm{L}$, faixa considerada mínima para ocorrência da nitrificação. Essa constatação é muito relevante, uma vez que o consumo de energia elétrica para aeração do sistema deverá ser substancialmente maior relativamente ao processo de lodo ativado apenas com biomassa em suspensão, em que a concentração de oxigênio dissolvido é mantida entre 1,0 e 2,0 $\mathrm{mg} \mathrm{O}_{2} / \mathrm{L}$.

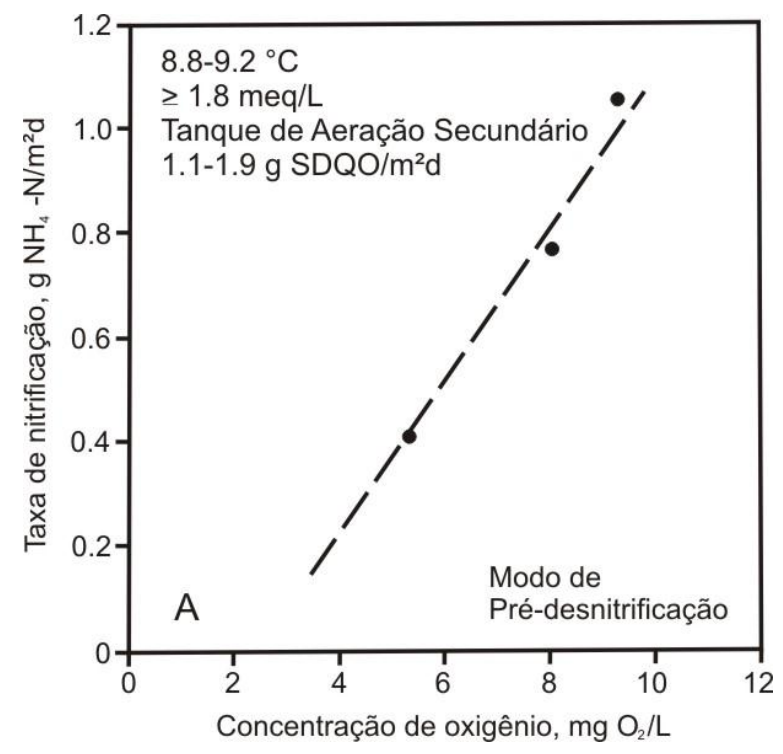

Figura 3 - Relação entre taxa de nitrificação e concentração de oxigênio dissolvido em sistema com MBBR em escala piloto (Rusten et al, 1995)

Com relação à desnitrificação, em virtude de o esgoto da Noruega possuir baixa concentração de carbono orgânico facilmente biodegradável, foram registradas baixas velocidades no sistema com MBBR e pré-desnitrificação, pois neste processo, a hidrólise e utilização da matéria orgânica particulada são limitadas devido ao baixo tempo de retenção hidráulica. Rusten et al. (1995), obtiveram a taxa máxima de desnitrificação de $200 \mathrm{gN}-\mathrm{NO}_{x} / \mathrm{m}^{3}$.d. A velocidade de desnitrificação demonstrou-se diretamente proporcional à DQO solúvel biodegradável. Porém, 
foram verificados níveis altos de concentração de oxigênio dissolvido, acima de 3,4 $\mathrm{mg} / \mathrm{L}$, que também contribuíram para a baixa taxa de desnitrificação.

\subsubsection{Descrição Geral dos Sistemas}

Um sistema MBBR pode ser constituído de um único reator ou vários reatores em série, e é composto de componentes básicos que serão mais bem descritos na sequência do texto, e consistem em suportes plásticos para biofilme, peneiras para retenção dos elementos suporte, um sistema de aeração difusa, e sistemas de agitação para os tanques anóxicos. Todos esses elementos ficam submersos e devem ser especificados para uma adequada durabilidade considerando a exposição aos ambientes previstos.

O preenchimento com suportes plásticos móveis pode variar de 25 a $70 \%$ do volume líquido de um reator. Esses elementos são fabricados em polietileno e têm densidade específica entre 0,94 e 0,96 g/ $\mathrm{cm}^{3}$. Em condições em que a massa líquida está calma, com os mecanismos de agitação desligados, os suportes móveis tendem a flutuar (WEF, MOP No. 8, 2009).

Para fins de projeto é considerada apenas a área superficial localizada no interior do suporte e, portanto protegida contra a abrasão provocada pelas colisões com os demais elementos, fato que também trás como conseqüência o favorecimento para desenvolvimento de biofilmes com reduzida espessura, como desejado por um controle efetivo de espessura de biofilme. As áreas superficiais específicas podem variar largamente. Minegatti (2008) apresentou um intervalo de 190 a $614 \mathrm{~m}^{2} / \mathrm{m}^{3}$ de suportes plásticos móveis variando de acordo com o fabricante e o produto.

É conveniente que a quantificação da taxa de aplicação de carga seja feita em termos do fluxo superficial de substrato $\left(r_{s f}\right), \mathrm{g} / \mathrm{m}^{2} . \mathrm{d}$. Para isso, a carga volumétrica pode ser dividida pela área superficial específica efetiva, resultando na taxa de aplicação superficial, g/m².d (RUSTEN et al., 1998).

Mesmo com agitação, os suportes podem tender a flutuar quando inicialmente introduzidos nos reatores com água, mas esse efeito deve acabar em poucos dias conforme o biofilme se desenvolva. Para a oxidação de material carbonáceo o tempo esperado para desenvolvimento é de 2 a 15 dias, para a oxidação de amônia a 
expectativa básica é de quatro semanas para ocorrência do processo mas para alcance do regime permanente devem ser necessários de 60 a 120 dias. O mesmo prazo deve ser esperado para a desnitrificação já que essa etapa depende da nitrificação.

Peneiras ou grades para retenção dos suportes de biofilme são instaladas ao longo de pelo menos uma das paredes do reator e permitem que o efluente tratado escoe para a próxima unidade do processo. As configurações mais comuns desses dispositivos são (1) no formato cilíndrico instaladas horizontalmente e frequentemente utilizadas para o efluente de tanques aeróbios e (2) planas instaladas verticalmente junto às paredes na saída de câmaras anóxicas. Na Figura 4 a fotografia mostra um detalhe de uma peneira cilíndrica instalada na saída de um reator aeróbio.

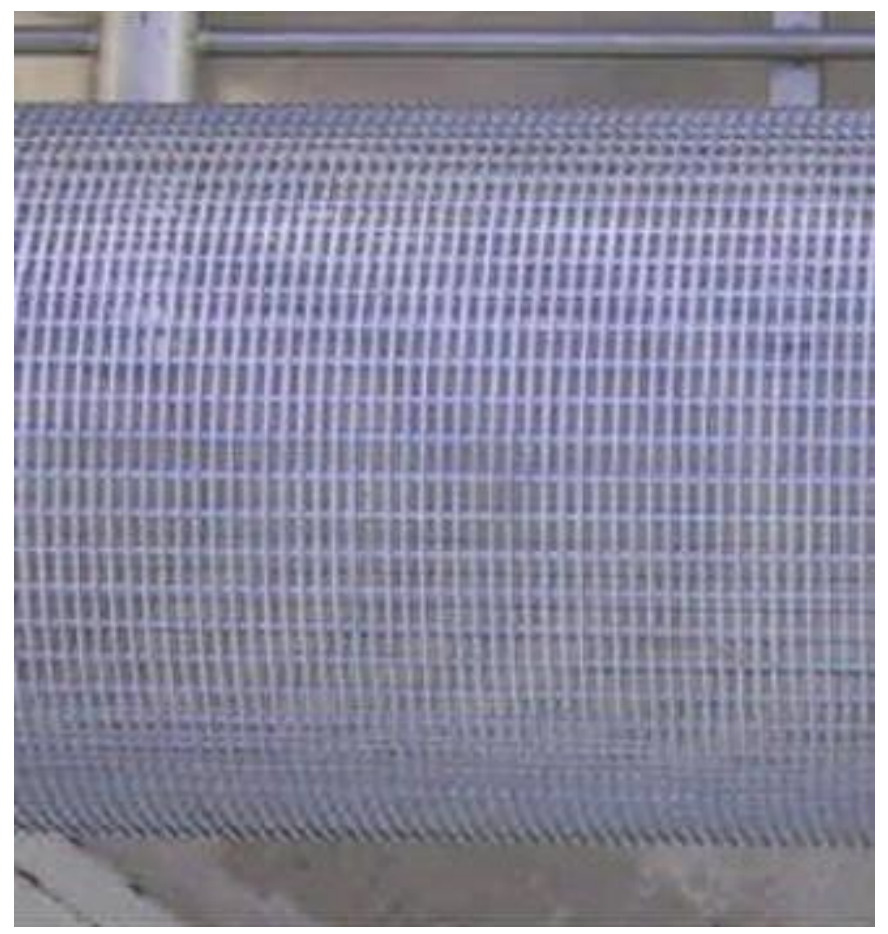

Figura 4 - Fotografia de um detalhe de uma peneira cilíndrica.

Um sistema de aeração é necessário para o suprimento da demanda de oxigênio dos reatores que realizam a oxidação e matéria carbonácea e eventualmente nitrificação e o sistema de difusão de ar também é utilizado para agitar e distribuir uniformemente os elementos plásticos ao logo do volume dos tanques. A turbulência provocada pela agitação provoca ainda a redução das resistências a transferências de massa externas ao biofilme. Os difusores devem ser instalados no fundo do 
tanque de aeração de modo a provocar uma movimentação circular da massa líquida para evitar o acúmulo de elementos suporte na superfície, como representado na Figura 5a. Podem ser utilizadas bolhas finas ou grossas para o suprimento de ar e agitação do meio líquido, entretanto, por requerer menor manutenção, sistemas de difusão por bolhas grossas tem sido mais utilizados historicamente (WEF, MOP No. 8, 2009).

Para a homogeneização dos suportes móveis deve ser instalado um sistema de agitação mecânica nas câmaras anóxicas (Figura 5b) considerando a impossibilidade de utilização da aeração para essa função. Os misturadores devem ter, como orientação de projeto, rotação máxima de $120 \mathrm{rpm}$ e ao menos três lâminas cada para alcançar os objetivos do processo e ao mesmo tempo evitar abrasão excessiva entre os elementos suporte.

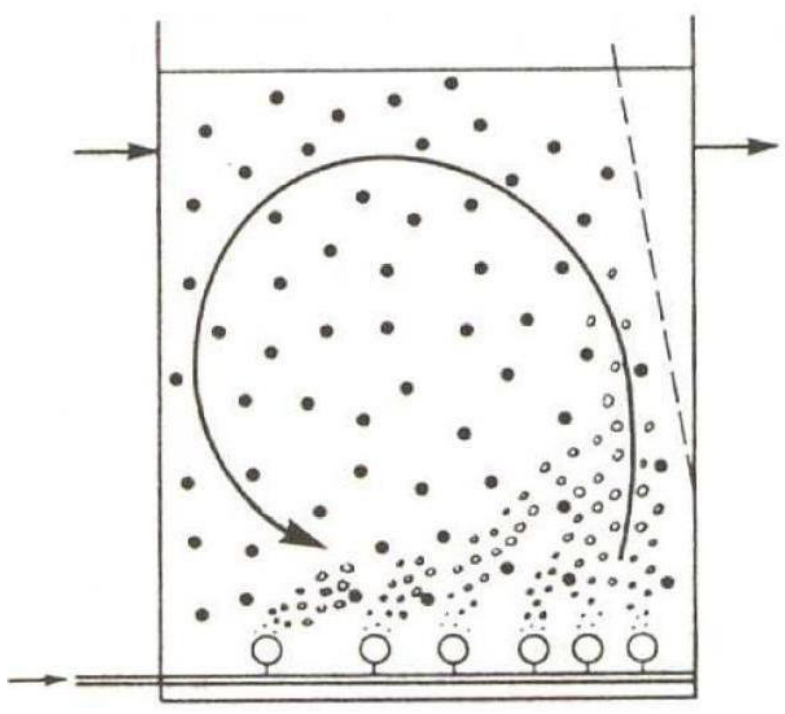

(a) Reator aeróbio

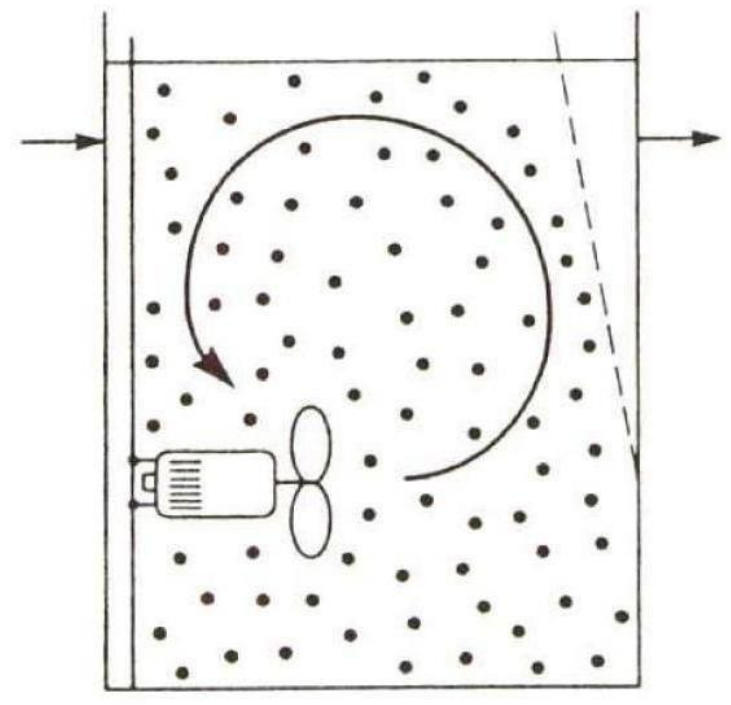

(b) Reatores anóxicos e anaeróbios

Figura 5 - Agitação em reatores (a) aeróbios, (b) anóxicos e anaeróbios (ØDEGAARD et al. 1994).

Rusten et al. (2000) documenta que o processo traz como vantagem para melhorias de estações existentes o fato de reduzir a carga de sólidos nos clarificadores existentes se comparado com um sistema de lodo ativado.

A adição de elementos suporte pode ser realizada de forma gradual, de forma que eventuais desvios dos desempenhos das plantas de tratamento em relação aos previstos em projeto podem ser corrigidos com variações das quantidades de suportes plásticos móveis utilizadas. Essa adição controlada de meio suporte 
também oferece a possibilidade de aumento do preenchimento conforme a evolução da carga de poluentes afluente à estação de tratamento de esgotos.

\subsubsection{Orientações de Projeto}

A concepção dos sistemas que utilizam a tecnologia MBBR inclui a consideração dos seguintes aspectos:

- Objetivos específicos do tratamento;

- Características do esgoto afluente; e

- Geometria da área de implantação,

para plantas novas. Em casos de adaptações de sistemas existentes, devem ser adicionados ainda outros levantamentos:

- Configuração dos tanques existentes;

- Hidráulica do sistema;

- Esquema de tratamento; e

- Potencial para adaptação dos tanques.

O crescimento de biofilmes em sistemas MBBR varia de acordo com a configuração e objetivos do tratamento, sejam a remoção de matéria orgânica, nitrificação em estágio separado ou juntamente com a oxidação carbonácea e desnitrificação, bem como das condições ambientais particulares de cada planta (WEF, MOP No. 8, 2009).

Sistemas novos ou adaptações podem ser compostos de unidades de tratamento primário, incluindo até mesmo soluções com melhoria do desempenho com aplicação de produtos químicos. Nesses casos as parcelas de sólidos e DQO que podem ser retidas aliviam consideravelmente o processo biológico e, especialmente em sistemas MBBR puros, que têm baixa capacidade de biofloculação, podem proporcionar uma melhor eficiência global na remoção de sólidos em suspensão e DQO não solúvel e não biodegradável.

Também é usual o emprego de reatores em série de forma que as concentrações de substrato sejam progressivamente menores à medida que o efluente avança através dos reatores. Essa prática também é empregada com o intuito de viabilizar a nitrificação otimizando a utilização do volume dos tanques, mantendo os reatores 
iniciais dedicados preferencialmente à remoção de matéria orgânica. Variantes dessa configuração compreendem a operação de reatores iniciais apenas com biomassa em suspensão.

Combinações sistemas de lodo ativado convencional com reatores MBBR podem também ser utilizadas com as seguintes configurações:

- Pré-tratamento de um sistema de lodo ativado convencional para ampliação de sua capacidade;

- Pós-tratamento de um sistema de lodo ativado convencional para remoção de nitrogênio. Nesse caso pode ser necessária a instalação de unidade de separação de sólidos complementar.

Pode ser prevista a remoção química de fósforo com adição de coagulante no efluente encaminhado para as unidades de separação de sólidos, sem diferenças em relação a sistemas de lodo ativado.

A desnitrificação pode ser obtida com a utilização de reatores de pré-desnitrificação, pós-desnitrificação ou ambos. Nos casos de pós-desnitrificação, naturalmente, é necessária a adição de fonte de carbono.

\subsection{Reatores Híbridos}

Um sistema híbrido combina biomassa em suspensão e fixa num mesmo reator. Diversos tipos de materiais sintéticos foram desenvolvidos para uso em suspensão no licor misto em processos de lodo ativado e Sen et al. (1994) usou o termo IFAS (integrated fixed-film activated sludge) ou processo integrado com biomassa fixa e lodo ativado. A intenção é melhorar o desempenho do sistema de lodo ativado pelo fornecimento de maior quantidade de biomassa por unidade de volume de reator. Também é utilizado quando o objetivo é alcançar a nitrificação, aumentar as taxas volumétricas de nitrificação ou até mesmo realizar a desnitrificação em tanques de aeração considerando a utilização de zonas anóxicas no interior do biofilme (Metcalf \& Eddy, 2003).

Vantagens do uso de um sistema híbrido são apresentadas a seguir (WEF, MOP No. 29, 2005): 
- Acréscimo de biomassa para o tratamento com mínima adição de carga de sólidos para as unidades de separação de sólidos;

- Aumento da capacidade de tratamento por unidade de volume de reator;

- Melhoria das características de sedimentabilidade;

- Redução da produção de lodo;

- Eventuais nitrificação e desnitrificação simultâneas;

- Operação semelhante à de um sistema de lodo ativado convencional; e

- Aumento da resistência a cargas de choque e lavagem.

O projeto de deve ser feito considerando o efeito combinado dos dois processos. Parâmetros típicos de projeto para um sistema IFAS são apresentados na Tabela 1.

Tabela 1 - Parâmetros típicos de projeto para um sistema IFAS.

\begin{tabular}{lcc}
\hline \multicolumn{1}{c}{ Parâmetro } & Unidade & Intervalo \\
\hline Tempo de detenção anóxico & $\mathrm{h}$ & $1,0-1,2$ \\
Tempo de detenção aeróbio & $\mathrm{h}$ & $3,5-4,5$ \\
Área de Biofilme & $\mathrm{m}^{2} / \mathrm{m}^{3}$ & $200-250$ \\
Carga de DBO & $\mathrm{kg} / \mathrm{m}^{3} . \mathrm{d}$ & $1,0-1,4$ \\
Taxa de aplicação hidráulica em decantadores secundários & $\mathrm{m} / \mathrm{h}$ & $0,5-0,8$ \\
\hline
\end{tabular}
Metcalf \& Eddy (2003)

\subsubsection{Considerações de Projeto}

O projeto de sistemas IFAS considera a adição de uma parcela de biomassa fixa a reatores de lodo ativado considerando a operação com quantidades significativas de sólidos em suspensão, diferentemente de sistemas MBBR. O intervalo típico de concentração de sólidos em suspensão no licor misto varia de 1500 a 3500 mg/L. A recomendação para o tempo mínimo de detenção hidráulica aeróbica a $12{ }^{\circ} \mathrm{C}$ é de 4 horas (WEF, MOP No. 8, 2009). Uma configuração típica de um sistema IFAS com suportes plásticos móveis contando com câmara de pré-desnitrificação com a possibilidade de emprego de meio suporte plástico e reator aeróbio eventualmente dividido em células é apresentado da Figura 6. 


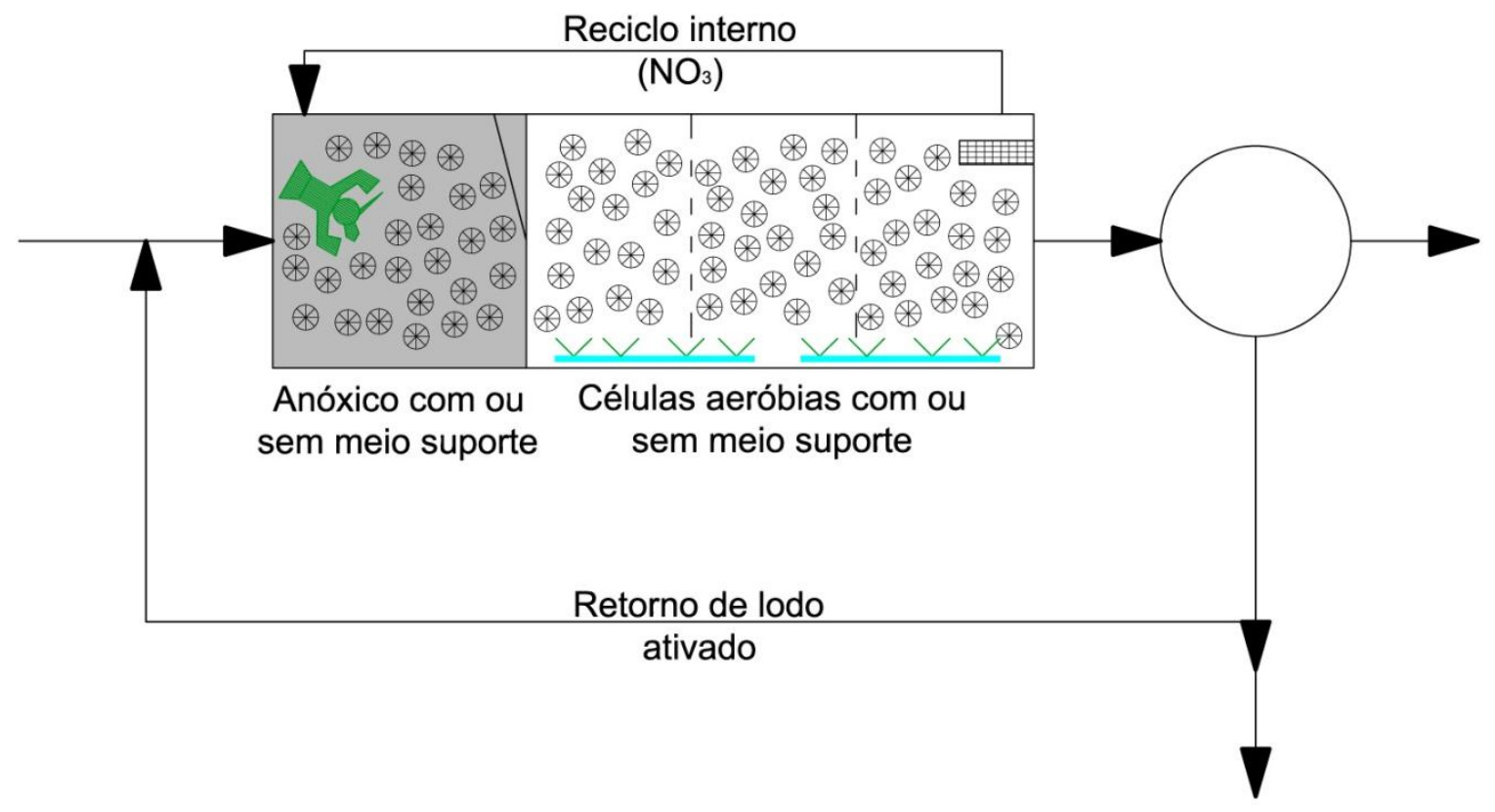

Figura 6 - Configuração típica de sistema IFAS com suportes plásticos móveis.

\subsubsection{Parâmetros de Projeto}

A remoção de compostos orgânicos pelo biofilme em sistemas híbridos, assim como ocorre com sistemas MBBR, é influenciada principalmente por dois parâmetros, as taxas de fluxo no biofilme e as remoções por unidade de volume de reator.

A taxa de fluxo no biofilme é a taxa de transporte do substrato através da interface massa líquida/biofilme, ou a MTBL e sua unidade típica é $\mathrm{g} / \mathrm{m}^{2}$.d. Pode ser utilizada para análises da utilização de DQO, oxigênio dissolvido, nitrogênio amoniacal, nitrato, sólidos suspensos voláteis e sólidos inertes. É função das concentrações dos substratos no licor misto, da espessura de biofilme, da densidade de biomassa no biofilme, e da espessura da MTBL (WEF, MOP No. 8, 2009).

Podem ser consideradas como taxas de fluxo de referência para projeto, considerando (1) relações DQO/NKT no afluente ao reator variando de 7,5:1 a 15:1, (2) temperatura de $15^{\circ} \mathrm{C}$ e (3) concentração de oxigênio dissolvido de $3 \mathrm{mg} / \mathrm{L}$ as seguintes (WEF, MOP No. 8, 2009):

- Consumo aeróbio de DQO: 0,5 a 5,0 g/m².d;

- Nitrificação: 0,05 a $0,5 \mathrm{~g} \mathrm{NH}_{3}-\mathrm{N} / \mathrm{m}^{2}$.d. 
A remoção que ocorre por unidade de volume de reator devida à biomassa aderida, enquanto parâmetro, é uma função do fluxo de um determinado substrato, da área superficial específica do meio suporte e da fração de enchimento do reator com meio suporte. Pode ser expressa em kg/m³.d (WEF, MOP No. 8, 2009).

A remoção de matéria carbonácea devida aos sólidos em suspensão no licor misto é função da concentração de biomassa, concentração de substrato e de oxigênio dissolvido. Se a idade do lodo for aumentada, a concentração de sólidos em suspensão também aumentará, assim como em sistemas de lodo ativado convencionais. Como consequência a absorção de DQO também é maior, de modo que a quantidade a ser removida pelo biofilme é reduzida, reduzindo-se, assim, a área superficial de biofilme necessária. Portanto, em relação à parcela suspensa da biomassa, a idade do lodo ainda é o parâmetro mais importante de projeto.

A variação da idade do lodo também tem efeito sobre a proporção entre as parcelas de nitrogênio amoniacal oxidada em cada porção de biomassa, suspensa ou aderida, mas de modo diferente do que influencia a remoção de matéria orgânica. $O$ efeito sobre as parcelas removidas de matéria orgânica é simplesmente função da quantidade de biomassa em suspensão, já que as bactérias heterotróficas sempre existem, independentemente da idade do lodo. No caso das bactérias autotróficas que oxidam os compostos nitrogenados a presença é dependente da idade do lodo por consequência do fenômeno da lavagem. Em baixas idades do lodo, calculadas apenas em relação à biomassa em suspensão, as bactérias nitrificantes não se mantém no sistema senão integradas ao biofilme, porque a taxa de crescimento é menor que a taxa de descarte. Quanto maior a idade do lodo mais essas bactérias ocorrem também em suspensão.

Proporções das remoções baseadas em análises feitas com modelos cinéticos são apresentadas na Tabela 2. Esses valores orientam a definição da área superficial de biofilme requerida.

Os valores apresentados são uma indicação da tendência do comportamento dos sistemas, e devem ser utilizados quando não há possibilidade de estimar esse aspecto de modo mais adequado, seja por estudos em escala piloto ou pela modelagem cinética do sistema em questão. Há ainda a possibilidade de estudar o sistema em escala real quando se tratar de um caso de adequação de uma planta 
existente ou da necessidade de desenvolvimento de uma ferramenta para apoio à operação de um sistema IFAS que já esteja em operação.

Tabela 2 - Frações de remoção no biofilme recomendadas a $15^{\circ} \mathrm{C}$.

\begin{tabular}{ccc}
$\mathbf{R}_{\mathbf{s}}$ SSTA * & DQO & NH3-N \\
(d) & $\%$ & $\%$ \\
\hline 2 & 50 & 80 \\
4 & 25 & 50 \\
8 & - & 20 \\
\hline
\end{tabular}

* Idade do lodo em relação à biomassa em suspensão

WEF, MOP No. 8, 2009

Observa-se na Tabela 2 que mesmo em idades do lodo muito baixas ainda se espera uma pequena ocorrência de nitrificação na biomassa em suspensão. Isso é parcialmente devido ao fato de ocorrer continuamente a semeadura de bactérias nitrificantes na massa líquida que se desprendem do biofilme.

O binômio (1) concentração de sólidos em suspensão versus (2) área superficial de biofilme deve ser equilibrado de modo a otimizar os objetivos de projeto. Variações do primeiro podem resultar em variações no segundo, diretamente, ou variações da espessura do biofilme mantendo-se fixa a área superficial disponível.

Uma abordagem alternativa de projeto pode ser a utilização de uma idade do lodo equivalente que consiste na razão entre a quantidade de biomassa em suspensão e aderida somadas e a quantidade de descarte diário de lodo. Existem relações entre a idade do lodo equivalente e os desempenhos esperados do processo fornecidas por fabricantes. A realização de estudos em escala piloto e aplicação dos resultados ao projeto final segue o mesmo princípio. 


\section{MATERIAIS E MÉTODOS}

\subsection{Instalações das unidades experimentais}

A pesquisa foi desenvolvida por meio de experimento em escala piloto, procedendo com a operação de dois sistemas de lodos ativados de dimensões iguais, diferindo pela introdução em um deles de corpos móveis para o desenvolvimento de biomassa aderida, caracterizando um sistema IFAS. As unidades piloto foram instaladas no campo experimental de tratamento de esgoto do Centro Tecnológico de Hidráulica (CTH) Escola Politécnica da USP, Departamento de Engenharia Hidráulica e Sanitária. O esgoto sanitário utilizado para alimentação das unidades piloto foi proveniente do CRUSP - Conjunto Residencial da USP, composto dos esgotos dos apartamentos e do Restaurante Universitário, recebendo tratamento preliminar por peneiramento fino mecanizado, desarenação em caixa de areia do tipo canal e caixa de gordura.

O esgoto era recalcado do CRUSP para o $\mathrm{CTH}$, através de uma elevatória nova, construída em substituição à anteriormente existente que foi demolida por ocupar área utilizada para construção de novo bloco de apartamentos. É constituída por poço de sucção executado em concreto armado, duas bombas submersíveis, comporta para fechamento da chegada de esgoto, válvulas de retenção e acessórios para manobra para bloqueio dos conjuntos e descarga da linha de recalque.

Na chegada ao terreno do CTH foi necessária a substituição do trecho da tubulação de recalque compreendido entre a descarga localizada no interior do terreno e a chegada ao tratamento preliminar. Uma obra foi realizada sobre o traçado da tubulação existente. Foi implantada uma tubulação de $150 \mathrm{~mm}$ de diâmetro em PVC com aproximadamente $200 \mathrm{~m}$ de extensão. Após o tratamento preliminar, o esgoto é recalcado por bomba de deslocamento positivo, com velocidade variável por inversor de frequência, para o interior do galpão onde as instalações em escala piloto foram montadas. A fotografia da Figura 7 mostra o poço de sucção da estação elevatória de esgoto bruto localizada junto ao CRUSP. 


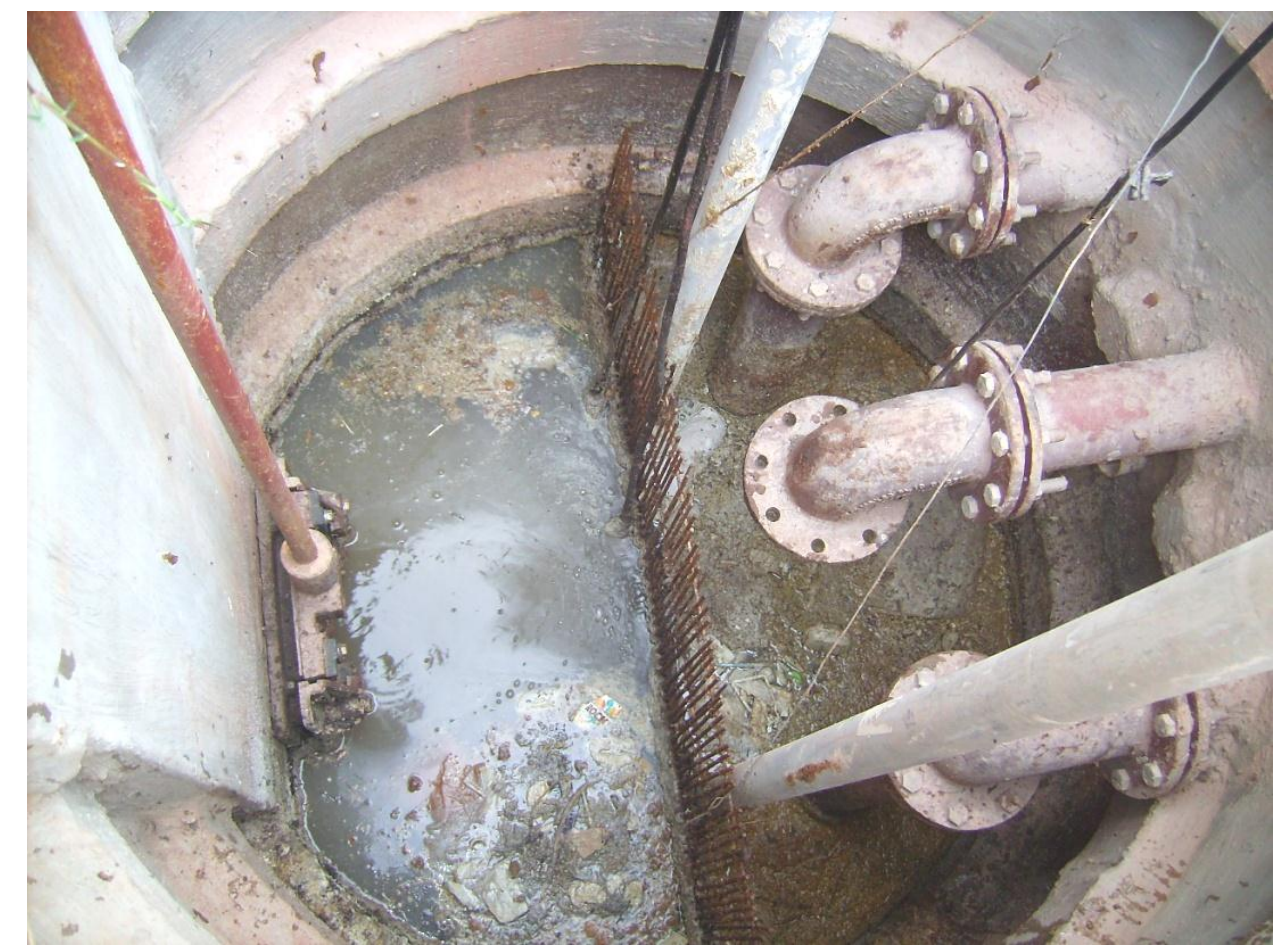

Figura 7 - Vista da estação elevatória de esgoto bruto.

O tratamento preliminar é ilustrado pela fotografia da Figura 8 e a bomba de deslocamento positivo de transferência de esgoto pré-tratado está apresentada na Figura 9.

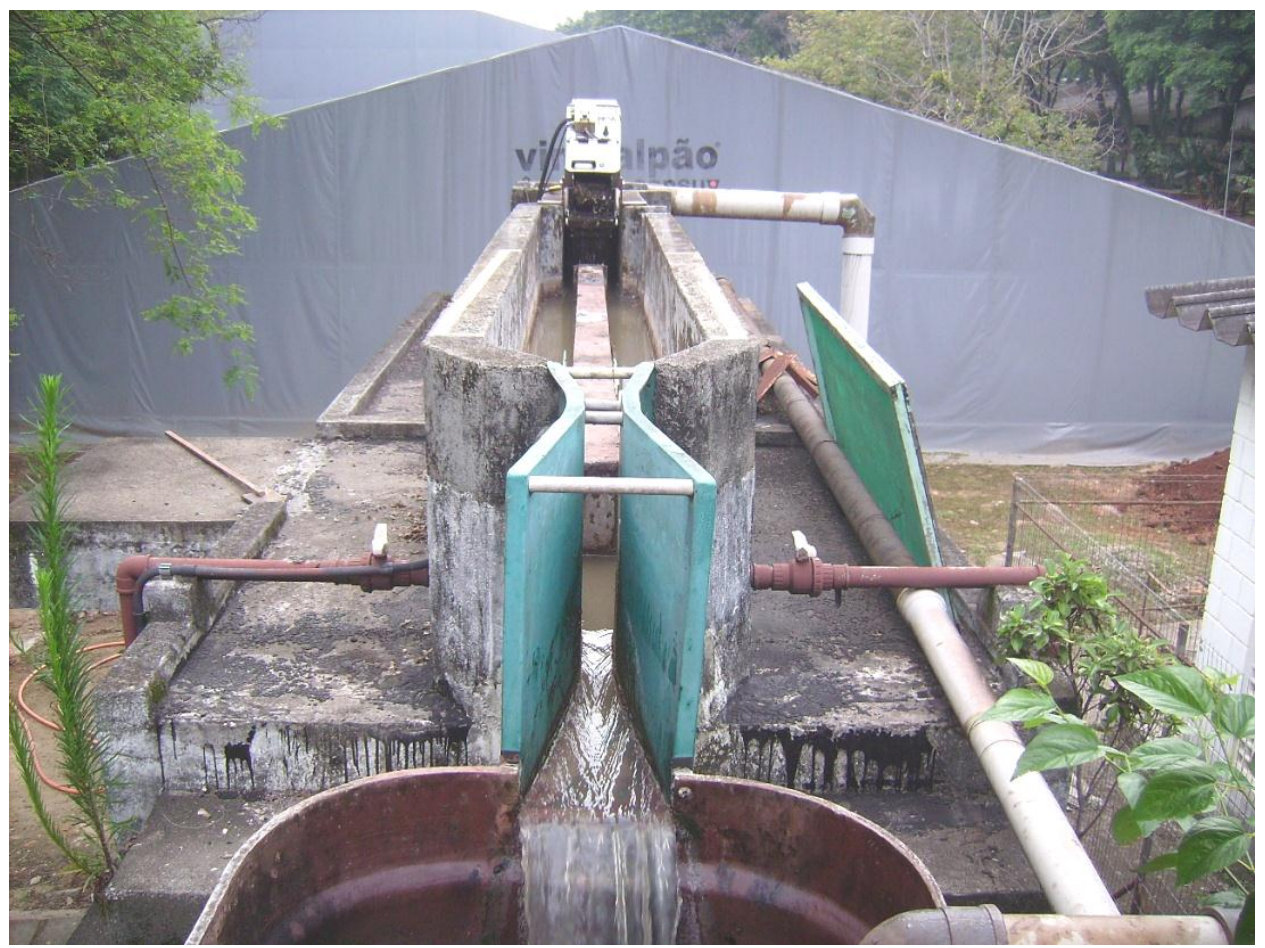

Figura 8 - Vista geral do tratamento preliminar. 


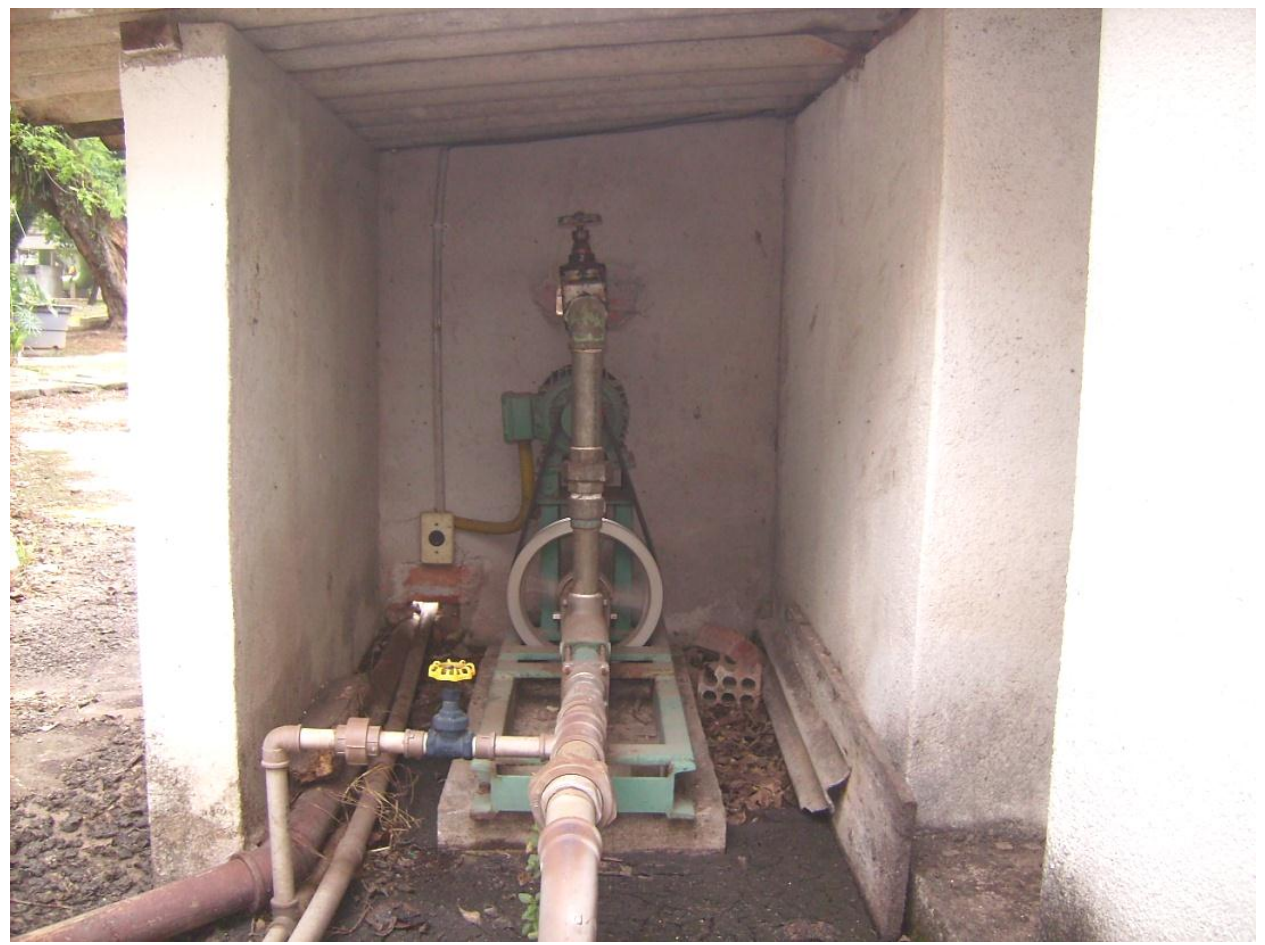

Figura 9- Bomba de transferência de esgoto pré-tratado.

Para alimentação das unidades piloto utilizadas no presente trabalho e para as demais demandas para outras pesquisas realizadas na mesma área, o esgoto prétratado era descarregado em um reservatório elevado de equalização com $2.000 \mathrm{~L}$ de volume total, composto por duas caixas de fibro-cimento de 1.000 de volume unitário. Da equalização o esgoto era transferido por gravidade para o decantador primário sob vazão controlada de forma a manter o tempo de detenção hidráulica entre uma e duas horas. O esgoto decantado era descarregado em uma caixa de $500 \mathrm{~L}$ de volume útil total, de onde era recalcado para a entrada dos dois tanques de aeração mediante duas linhas de recalque de bombas de deslocamento positivo independentes. Na sequência da linha de escoamento, os lodos dos tanques de aeração são encaminhados por gravidade para os decantadores secundários, 0 mesmo ocorrendo em relação à descarga do efluente final.

As Figuras 10, 11, 12 e 13 a seguir apresentam fotografias das unidades de tratamento e sistemas de apoio. As unidades TQ1 e DEC1, na Figura 9, compõem o tratamento biológico do sistema 1, lodo ativado, e correspondem aos reatores biológicos (câmara anóxica e tanque de aeração) e decantador secundário. As unidades TQ2 e DEC 2 pertencem ao sistema 2, IFAS. O decantador primário ficou localizado abaixo da passarela de acesso aos reatores. Os bombeamentos das 
vazões de retorno de lodo ativado e reciclo interno de lodo ativado para as câmaras anóxicas de pré-desnitrificação foram realizados com bombas de deslocamento positivo.

Uma única linha de ar comprimido alimenta em paralelo os dois tanques, com vazões controladas por válvulas independentes. Cada câmara anóxica possui um misturador. Os reatores biológicos do sistema 2, IFAS, receberam adição de suportes plásticos móveis. Foi utilizado o produto K1 fabricado pela empresa Anox Kaldnes ${ }^{\circledR}$, atualmente pertencente ao grupo Veolia Water, com área superficial específica de $300 \mathrm{~m}^{2} / \mathrm{m}^{3}$ de material suporte. As frações de enchimento dos reatores biológicos anóxico e aeróbio foram de 0,3 e 0,5, respectivamente.

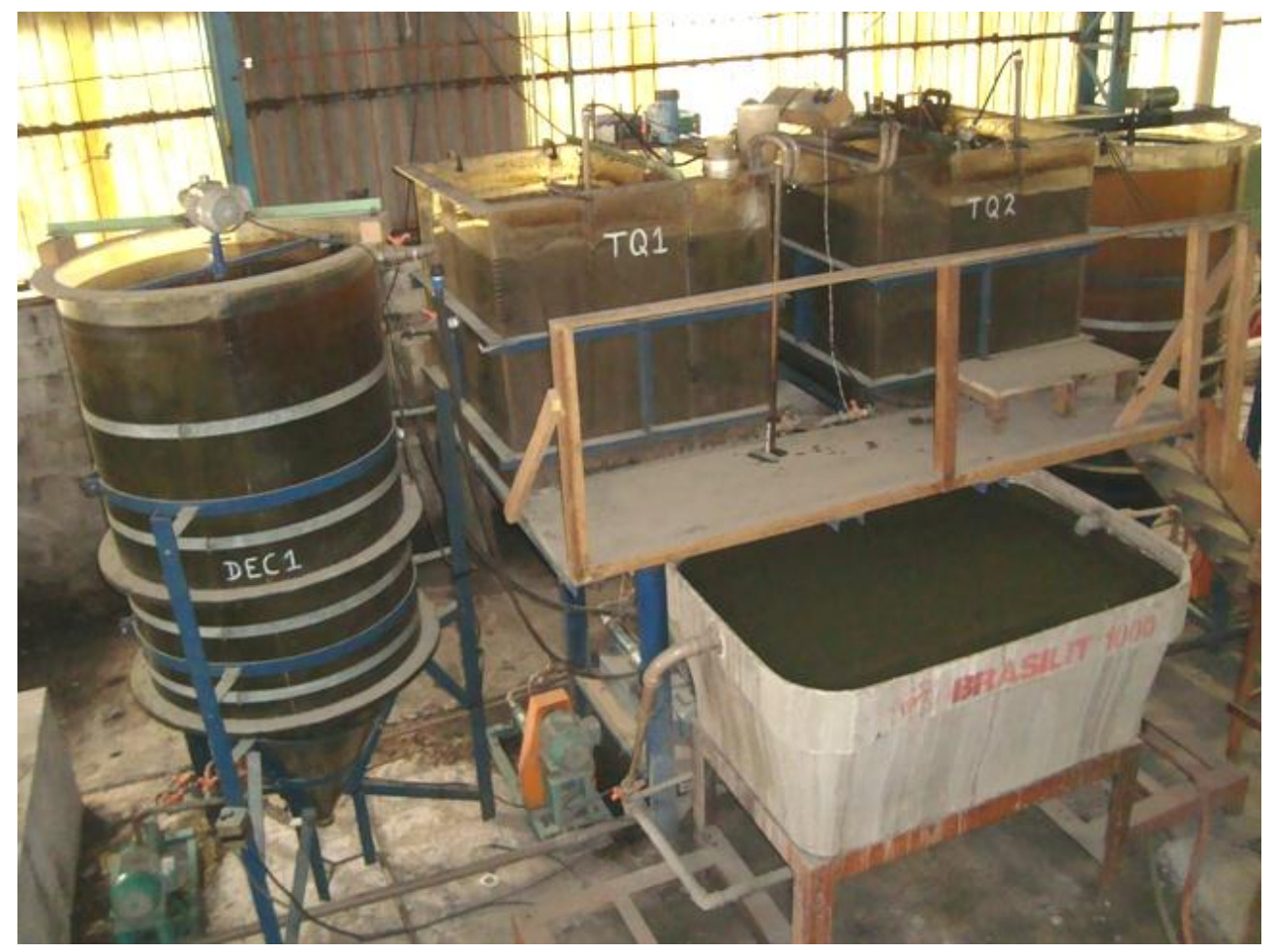

Figura 10 - Vista geral das unidades de tratamento.

Nos compartimentos anóxicos foram instalados sensores para monitoramento de $\mathrm{pH}$ e potencial de oxi-redução, enquanto que nos compartimentos aerados foram instalados sensores de oxigênio dissolvido. Os decantadores secundários possuem raspadores acionados por conjuntos moto-redutores elétricos. As bombas, raspadores dos decantadores secundários e misturadores das câmaras anóxicas possuíam sistemas de acionamento de velocidade variável. 


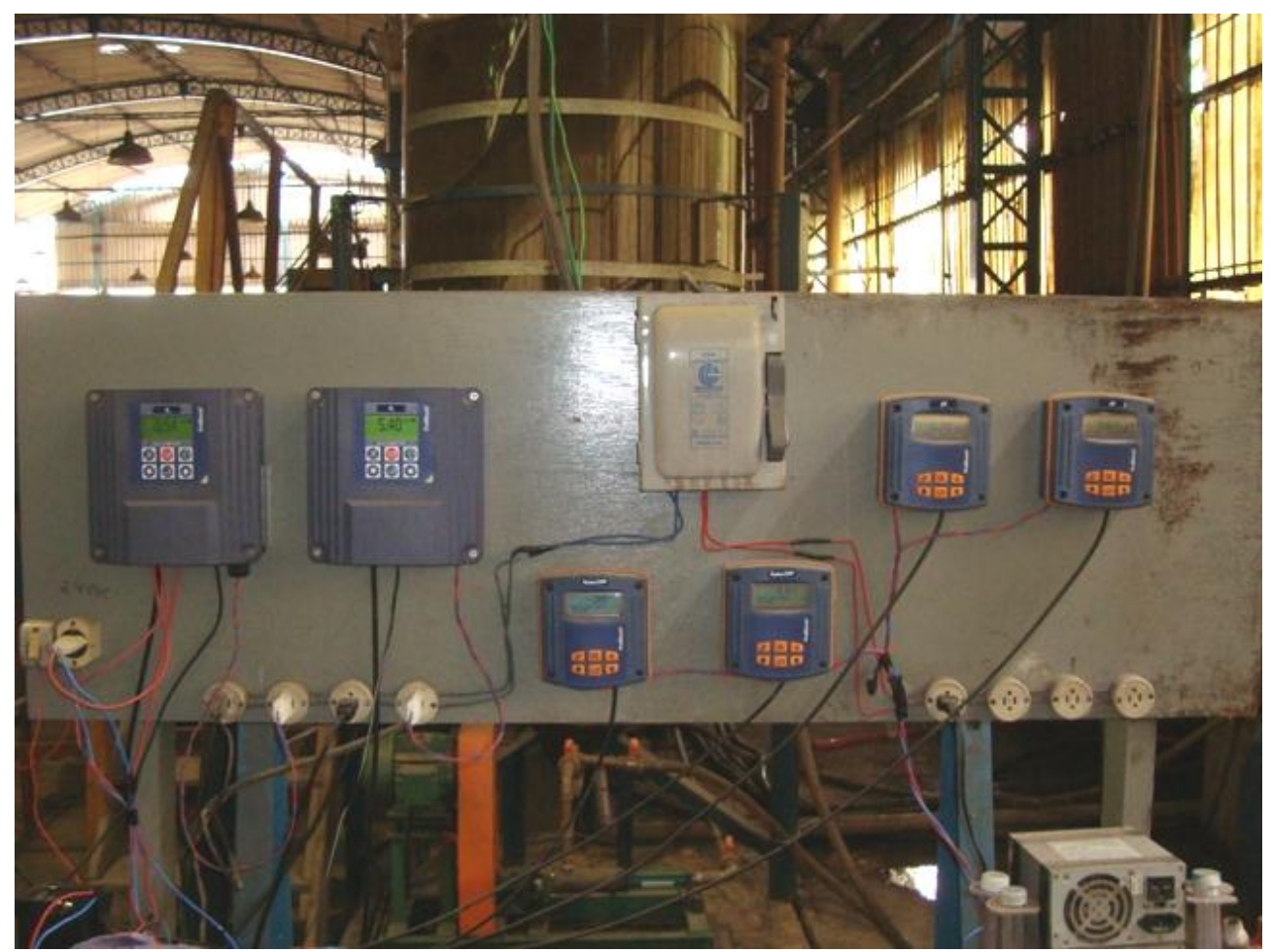

Figura 11 - Painel de interface da instrumentação.

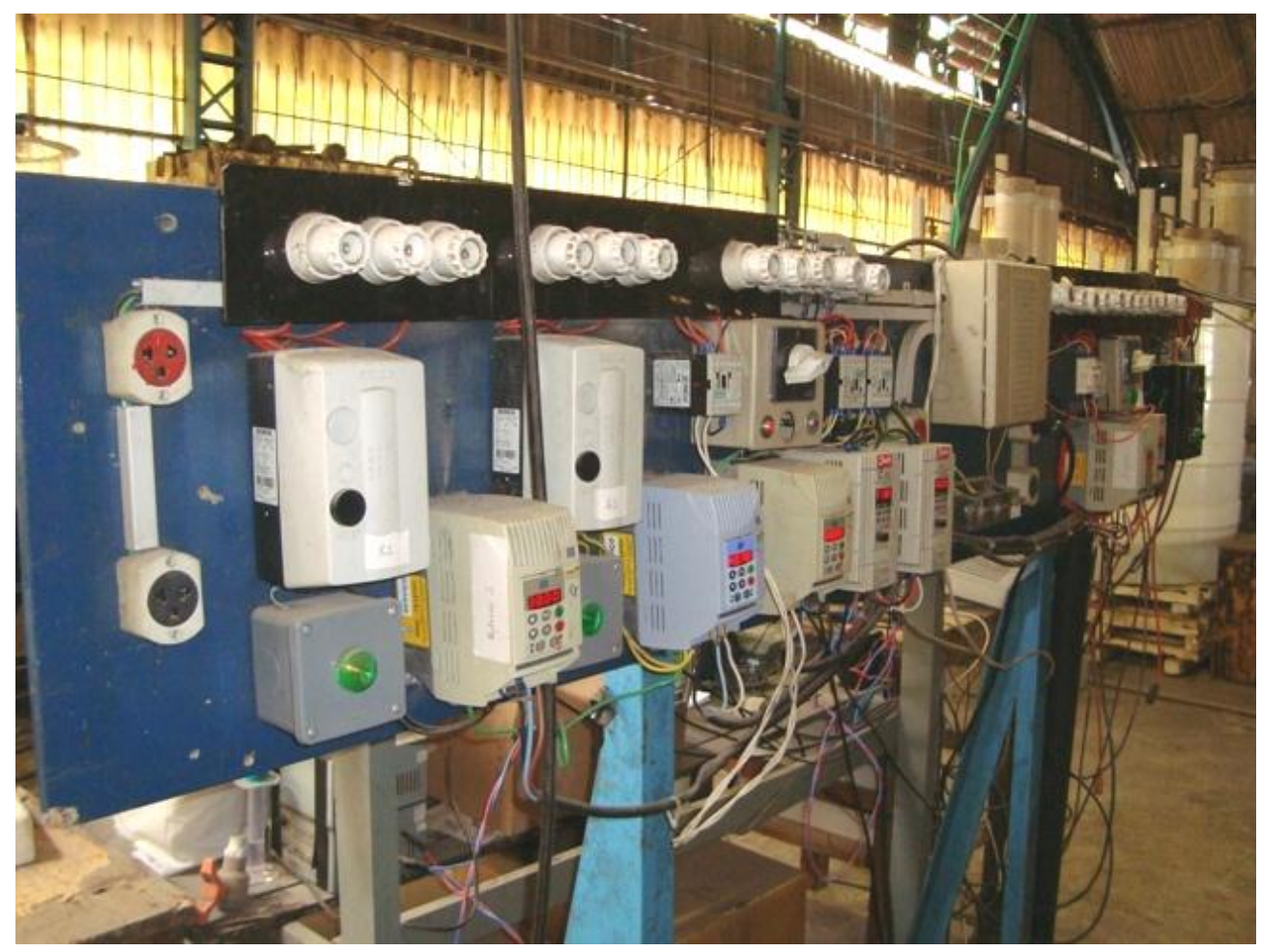

Figura 12 - Painel de controle dos equipamentos.

A Figura 13 mostra o analisador de oxigênio dissolvido instalado no tanque de aeração do sistema 2. Pode ser observado o aspecto da massa líquida agitada pelo 
sistema de aeração e obtida uma impressão visual da movimentação de suportes móveis.

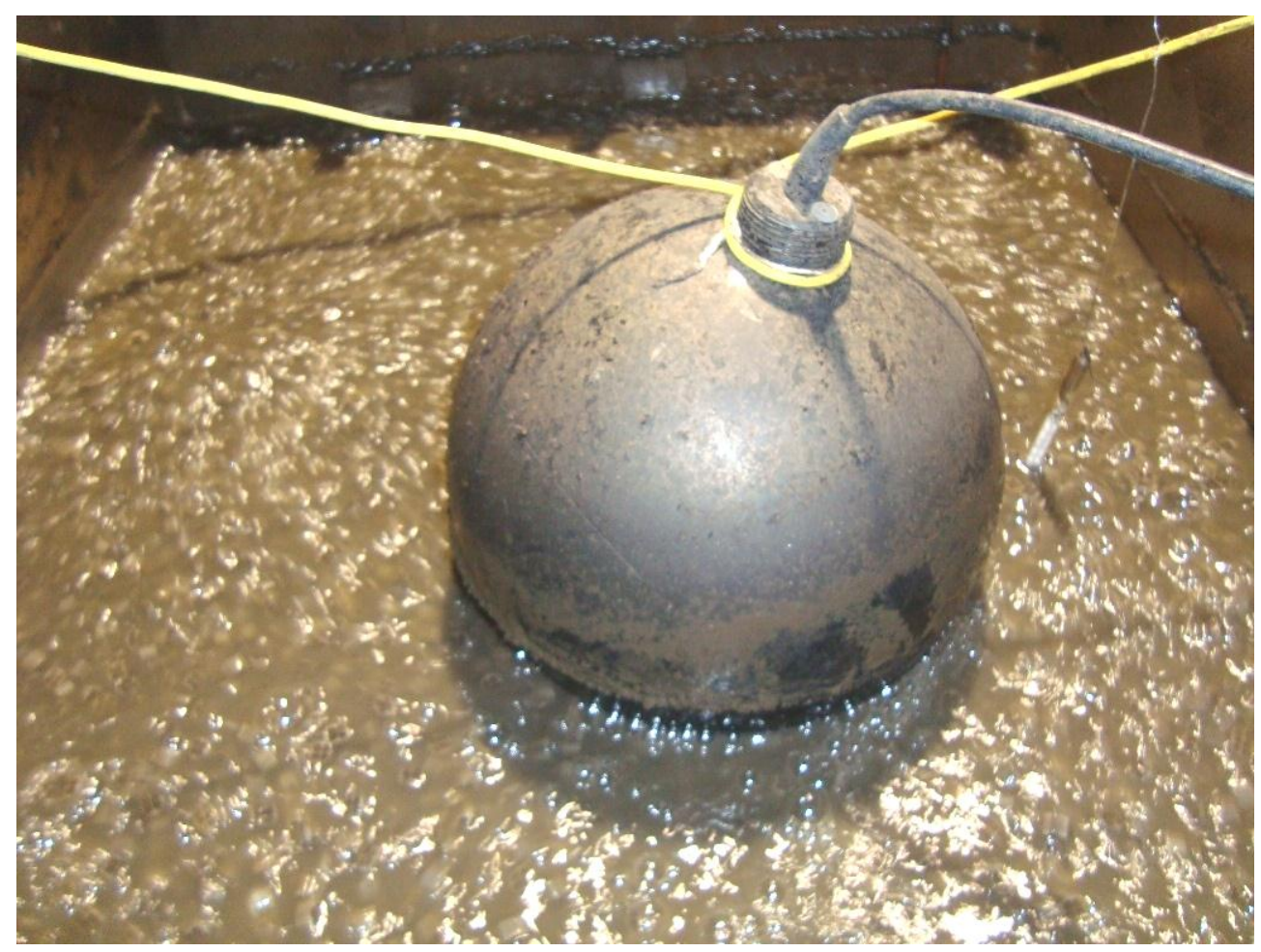

Figura 13 - Analisador de oxigênio dissolvido.

\subsection{Descrição das unidades de tratamento em escala piloto}

As unidades em escala piloto foram construídas a partir de reformas em outras duas existentes no campo experimental de tratamento de esgoto, no Centro Tecnológico de Hidráulica. Na Figura 14 apresenta-se um desenho esquemático das unidades que compuseram os sistemas de tratamento em escala piloto. As principais características dos sistemas são descritas a seguir.

\subsubsection{Tratamento primário}

Foi utilizado um único decantador primário, constituído de reservatório de fibrocimento de 0,8 $\mathrm{m}^{3}$ de volume útil, para atender aos dois sistemas que operaram em paralelo. A vazão de alimentação do decantador primário com o esgoto proveniente 
do tratamento preliminar foi mantida de forma a resultar em taxa de escoamento e eficiência típicos de decantadores primários de sistemas de lodo ativado.

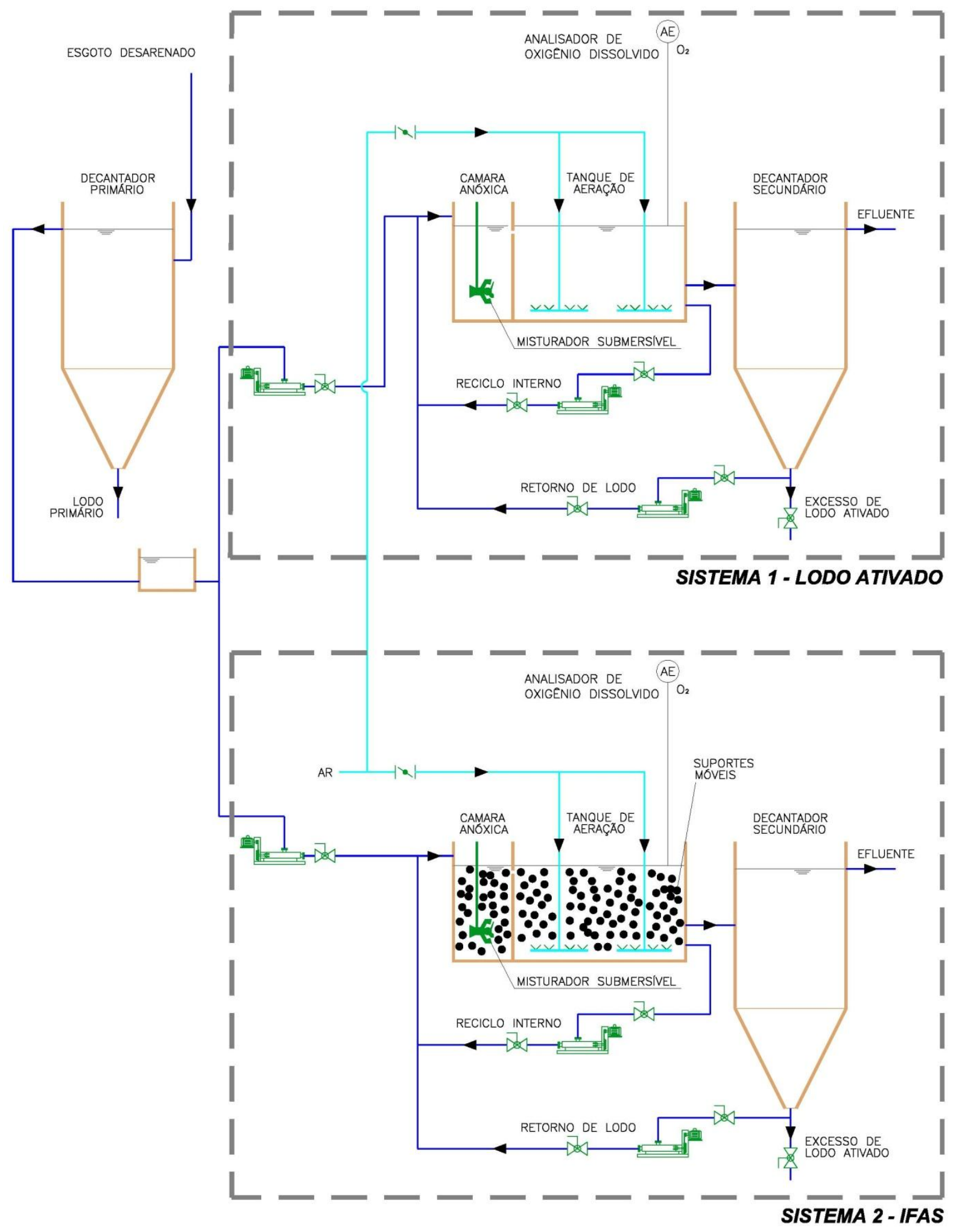

Figura 14 - Desenho esquemático dos sistemas em escala piloto. 


\subsubsection{Tratamento biológico}

Os reatores biológicos de ambos os sistemas piloto foram construídos em chapas de acrílico e divididos, cada um, em dois compartimentos, sendo que o primeiro foi provido de um misturador, trabalhando como câmara anóxica de pré-desnitrificação. O segundo compartimento operou como câmara aerada, contando com 4 difusores de bolhas finas de membrana instalados em seu fundo para a distribuição do ar fornecido por compressor. As características básicas dos reatores são apresentadas na Tabela 3. A Figura 15 ilustra a configuração dos reatores. As dimensões são as mesmas para os dois sistemas.

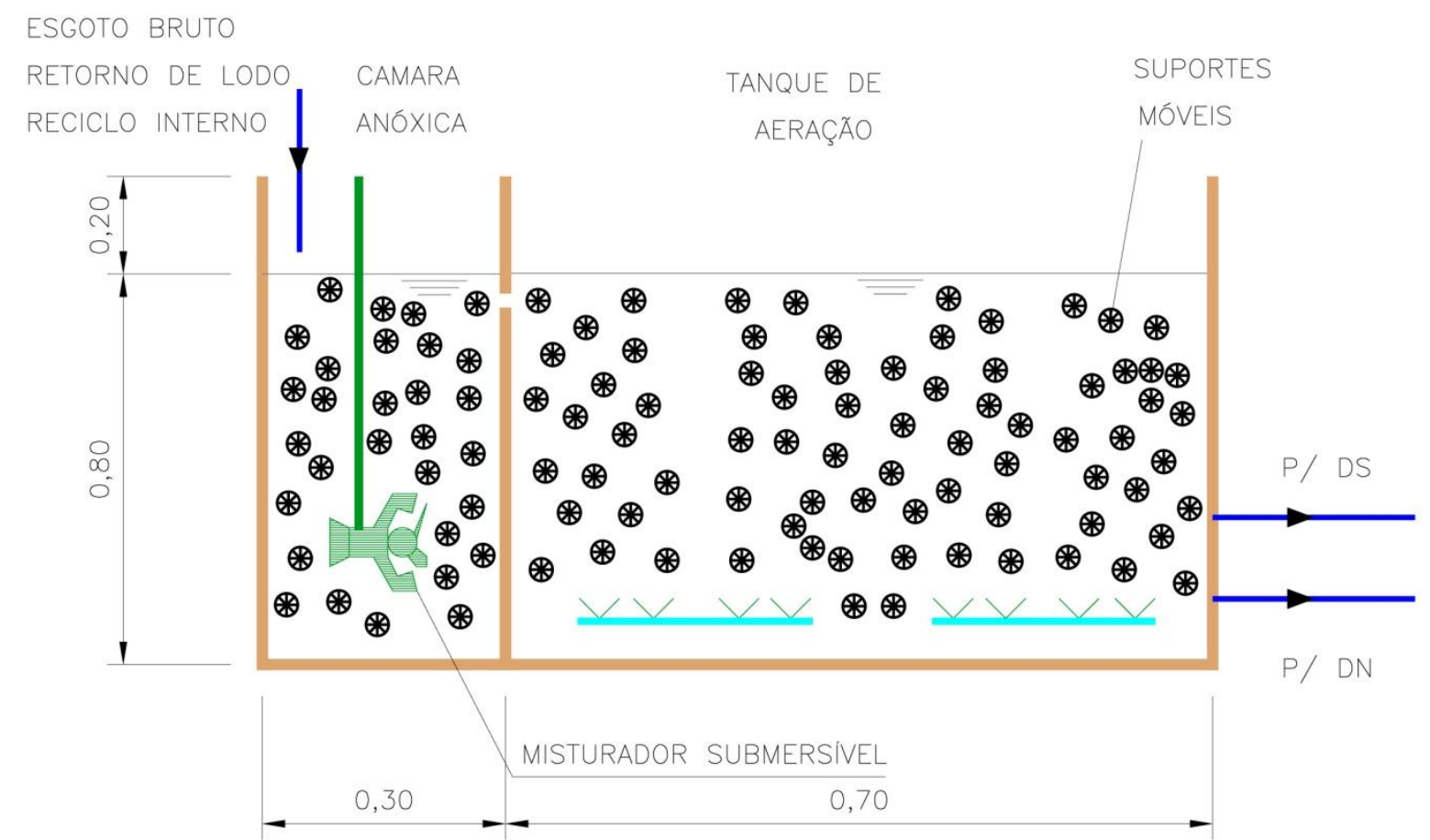

Figura 15 - Desenho esquemático dos reatores biológicos.

As dimensões dos suportes plásticos móveis são: diâmetro de $9 \mathrm{~mm}$, altura de $7 \mathrm{~mm}$.

Foram utilizados dois decantadores secundários de seção circular em planta (Figura 16), fabricados em acrílico e com raspadores de parede acionados por motor elétrico. As principais características dos decantadores secundários são:

- Área superficial: 0,785 $\mathrm{m}^{2}$;

- Volume útil: $1,47 \mathrm{~m}^{3}$. 
Tabela 3 - Dimensões básicas dos reatores biológicos.

\begin{tabular}{lcc}
\hline \multicolumn{1}{c}{ Reator } & $\begin{array}{c}\text { Câmaras } \\
\text { anóxicas }\end{array}$ & $\begin{array}{c}\text { Tanques de } \\
\text { aeração }\end{array}$ \\
\hline Volume total $\left(\mathrm{m}^{3}\right)$ & 0,28 & 0,66 \\
Volume útil $\left(\mathrm{m}^{3}\right)$ & 0,22 & 0,52 \\
Fração do volume de reatores (\%) & 30 & 70 \\
\hline
\end{tabular}

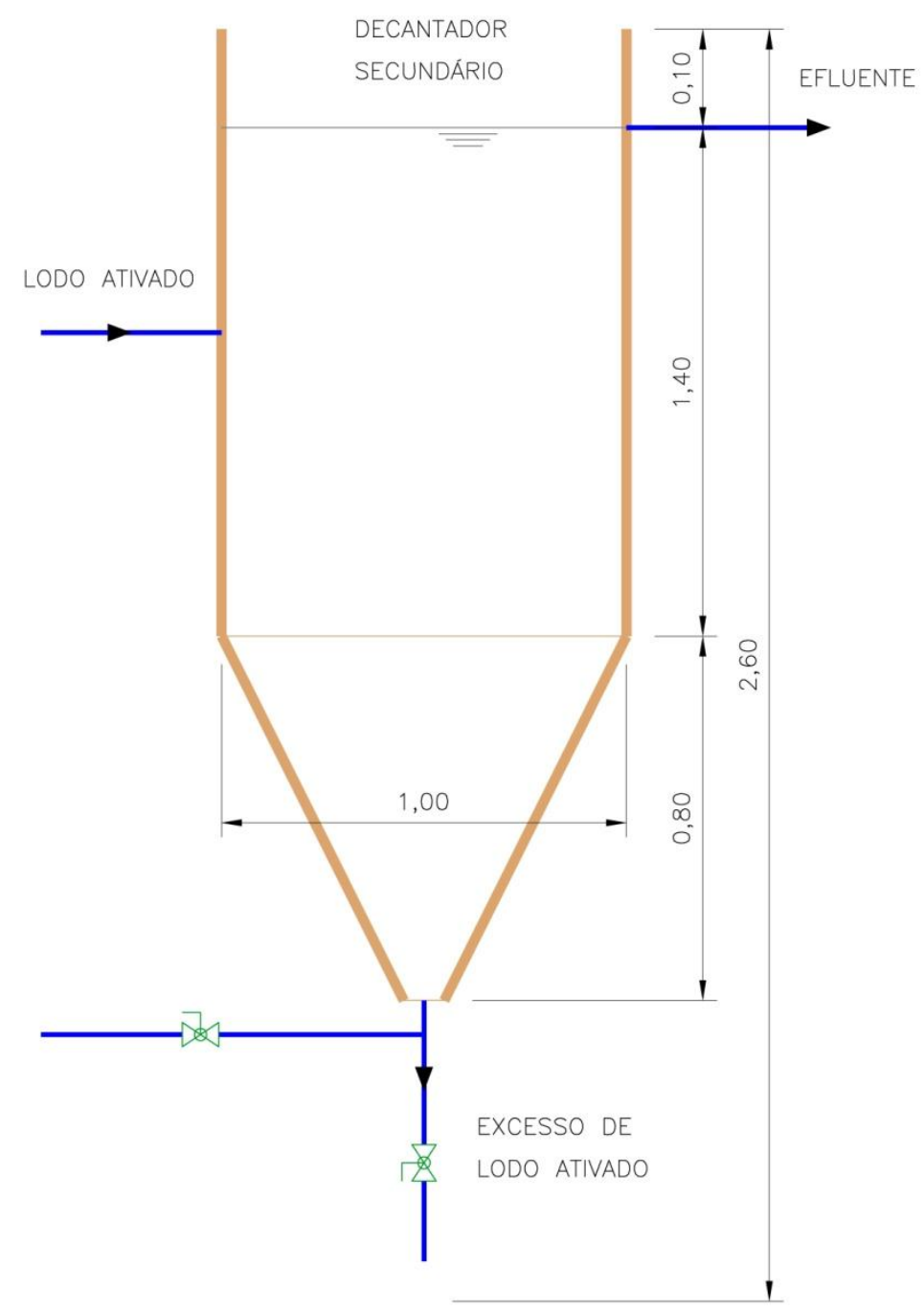

Figura 16 - Desenho esquemático dos decantadores secundários.

\subsection{Descrição dos procedimentos operacionais}

Para a pesquisa foram postos em operação e avaliados comparativamente os sistemas operando simultaneamente, com as mesmas idades de lodo, medidas em 
relação à biomassa em suspensão. As vazões de alimentação e consequentes relações alimento/microorganismos foram controladas para manter faixas inicialmente previstas.

Os dois sistemas em escala piloto foram postos em funcionamento após receberem lodo ativado de estação de tratamento de esgoto sanitário. Foram observados os procedimentos de partida, especialmente os indicados para o MBBR por GAUL et al. (2005).

Após atingir o regime estabilizado, cada sistema operou compondo 3 fases com idades do lodo diferentes, conforme previsto na Tabela 4. As durações das fases variaram de acordo com a observação do estabelecimento dos comportamentos esperados principalmente em relação à remoção de nitrogênio.

Tabela 4 - Condições operacionais mantidas nos reatores.

Lodo Ativado

\begin{tabular}{ccccc} 
Fase & $\begin{array}{c}\text { Relação A/M } \\
\text { (kgDBO/kgSSV.d) }\end{array}$ & $\begin{array}{c}\text { Idade do } \\
\text { Lodo (dias) }\end{array}$ & $\begin{array}{c}\text { Relação A/M } \\
\text { (kgDBO/kgSSV.d) }\end{array}$ & $\begin{array}{c}\text { Idade do Lodo } \\
\text { (dias) }\end{array}$ \\
\hline 1 & 0,2 & 9,3 & 0,2 & 9,3 \\
2 & 0,3 & 6,2 & 0,3 & 6,2 \\
3 & 0,4 & 4,6 & 0,4 & 4,6 \\
\hline
\end{tabular}

$\mathrm{Na}$ Tabela 4, as idades do lodo são referentes apenas à biomassa em suspensão. As relações alimento/microoganismos foram estimadas, supondo-se $90 \%$ de eficiência de remoção de DBO e considerando-se o coeficiente de síntese celular igual a 0,6 kgSSV $/ \mathrm{kgDBO}$ removida.

As vazões de alimentação dos dois sistemas em escala piloto (Tabela 5) foram preliminarmente definidas com base nas relações $\mathrm{A} / \mathrm{M}$ apresentadas na Tabela 4, considerando-se também os seguintes valores:

- Concentração de DBO do esgoto do CRUSP após tratamento primário: 215 $\mathrm{mg} / \mathrm{L}$

- Volume útil de cada tanque de aeração: $530 \mathrm{~L}$

- Concentração de SSV nos tanques de aeração: 3.000 mg/L

- Concentração de SST nos tanques de aeração: 4.000 mg/L 
Será considerada a utilização de bombas com capacidade de até cerca de $150 \mathrm{~L} / \mathrm{h}$. A vazão de retorno de lodo foi considerada preliminarmente como sendo da mesma ordem de grandeza ou inferior à vazão de esgoto, dimensionando-se sistemas de bombeamento de mesma capacidade que os de esgoto afluente. Foram instalados também sistemas de bombeamento para recirculação do lodo do compartimento aerado para o compartimento anóxico (reciclo interno), com capacidade de até cerca de $450 \mathrm{~L} / \mathrm{h}$.

Tabela 5 - Vazões de alimentação das unidades piloto com o esgoto

Lodo Ativado

IFAS

\begin{tabular}{ccccc} 
Fase & $\begin{array}{c}\text { Relação A/M } \\
\text { (kgDBO/kgSSV.d) }\end{array}$ & Vazão $\left(\mathbf{m}^{3} / \mathbf{d}\right)$ & $\begin{array}{c}\text { Relação A/M } \\
\text { (kgDBO/kgSSV.d) }\end{array}$ & Vazão $\left(\mathbf{m}^{3} / \mathbf{d}\right)$ \\
\hline 1 & 0,2 & 1,64 & 0,2 & 1,64 \\
2 & 0,3 & 2,45 & 0,3 & 2,45 \\
3 & 0,4 & 3,27 & 0,4 & 3,27 \\
\hline
\end{tabular}

Para a determinação da faixa necessária de vazão de ar, foi considerada a demanda de oxigênio carbonácea de $1,2 \mathrm{~kg} \mathrm{O} / \mathrm{kgDBO}$ aplicada. A demanda de oxigênio para a nitrificação é estimada em $4,57 \mathrm{~kg} \mathrm{O}_{2} / \mathrm{kgNH}_{4}{ }^{+}$. Considerando-se a concentração de nitrogênio amoniacal no esgoto de $70 \mathrm{mg} / \mathrm{L}$, a demanda máxima estimada de oxigênio foi de $3,8 \mathrm{kgO}_{2} /$ dia, correspondente à operação com relação $\mathrm{A} / \mathrm{M}$ de 0,4 $\mathrm{kg} \mathrm{DBO} / \mathrm{kg}$ SSV.dia.

O sistema de aeração é por ar difuso, utilizando-se difusores de bolha fina de EPDM. Para altura útil de $0,80 \mathrm{~m}$, a capacidade de transferência de oxigênio teórica foi estimada em cerca de $4 \%$. As correções para as condições de campo foram diferentes entre as duas unidades piloto, em vista que o processo de lodo ativado trabalhou no intervalo de 1,0 a 3,0 mg/L de concentração de oxigênio dissolvido no tanque, enquanto que o sistema com MBBR operou no intervalo de 3,0 a 4,0 mg/L. O sistema existente atendeu à demanda com folga.

Os decantadores secundários, na situação mais desfavorável, com vazão de alimentação de $3,27 \mathrm{~m}^{3} /$ dia e razão de recirculação de lodo de 0,5 , definida a partir da concentração de $6 \mathrm{~kg} \mathrm{SST} / \mathrm{m}^{3}$ no lodo da linha de retorno, trabalhou com a taxa 
de aplicação de sólidos de $0,52 \mathrm{~kg} \mathrm{SS} / \mathrm{m}^{2}$.h e taxa de escoamento superficial de $4,2 \mathrm{~m}^{3} / \mathrm{m}^{2} . \mathrm{d}$, valores bastante conservadores.

\subsubsection{Controle de vazões}

Duas vezes ao dia, as vazões de alimentação das unidades piloto foram aferidas e ajustadas, quando necessário. Foi determinada a quantidade de lodo a ser retirada de cada processo em cada fase operacional, procedendo-se os descartes diariamente. Os equipamentos instalados nas unidades piloto foram inspecionados diariamente e calibrados periodicamente.

O descarte de lodo foi realizado a partir dos decantadores secundários, onde se obtém uma concentração mais elevada de sólidos em relação aos tanques de aeração. As idades do lodo foram mantidas mediante a retirada diária de excesso de em quantidades calculadas sempre com base nas determinações mais recentes das concentrações de sólidos em suspensão voláteis nos lodos dos tanques de aeração, das linhas de retorno de lodo e do efluente final e nos volumes dos tanques de aeração e da vazão de alimentação.

\subsection{Sistema de monitoramento}

\subsubsection{Determinação das Características do Afluente e dos Efluentes}

Os pontos de amostragem estabelecidos foram:

- Ponto 1: Esgoto à saída do decantador primário;

- Ponto 2: Efluente final, sistema de lodo ativado;

- Ponto 3: Efluente final, sistema IFAS. 


\subsubsection{Variáveis Controladas, Pontos de Amostragem e Freqüências}

As variáveis controladas e as freqüências das análises são apresentadas na Tabela 6. As metodologias empregadas obedeceram à $21^{\text {a }}$ edição do Standard Methods for Examination of Water and Wastewater, da APHA / AWWA / WEF.

Tabela 6 - Variáveis controladas nos afluentes e efluentes, pontos de amostragem e freqüências.

\begin{tabular}{lcc}
\multicolumn{1}{c}{ Variáveis } & $\begin{array}{c}\text { Pontos de } \\
\text { Amostragem }\end{array}$ & Freqüência das Análises \\
\hline DQO & 1,2 e 3 & $2 \times$ semana \\
DQO - amostra filtrada & 2 e 3 & $2 \times$ semana \\
DBO $_{5,20}$ & 1,2 e 3 & $2 \times$ semana \\
DBO $_{5,20}$ - amostra filtrada & 2 e 3 & $2 \times$ semana \\
Nitrogênio Total Kjeldahl & 1,2 e 3 & $2 \times$ semana \\
Nitrogênio Amoniacal & 1,2 e 3 & $2 \times$ semana \\
Nitrito & 1,2 e 3 & $2 \times$ semana \\
Nitrato & 1,2 e 3 & $2 \times$ semana \\
Fósforo Total & 1,2 e 3 & $1 \times 15$ dias \\
Fósforo - amostra filtrada & 2 e 3 & $1 \times 15$ dias \\
Série Completa de Sólidos & 1,2 e 3 & $2 \times$ semana \\
Alcalinidade & 1,2 e 3 & $2 \times$ semana \\
pH & 1,2 e 3 & $2 \times$ dia \\
Temperatura & 1,2 e 3 & $2 \times$ dia \\
Sólidos Sedimentáveis & 1,2 e 3 & $1 \times$ semana \\
\hline & &
\end{tabular}

\subsubsection{Determinação das Características dos Lodos dos Reatores Biológicos}

Os pontos de amostragem estabelecidos foram:

- Ponto 4: Lodo do tanque de aeração do processo de lodo ativado;

- Ponto 5: Lodo do tanque de aeração do processo IFAS. 


\subsubsection{Variáveis Controladas, Pontos de Amostragem e Freqüências}

$\mathrm{Na}$ Tabela 7 apresenta-se uma síntese do controle laboratorial dos lodos dos reatores. As determinações de concentração de oxigênio dissolvido nos lodos biológicos, $\mathrm{pH}$, temperatura e potencial de óxido-redução serão determinados de forma contínua por meio de sensores instalados nos tanques de aeração. As determinações de densidades de bactérias nitrificantes (nitritantes e nitratantes) foram feitas conforme Standard Methods 21를 edição/2005 - método 9245 B.

Tabela 7 - Variáveis controladas nos lodos, pontos de amostragem e freqüências

\begin{tabular}{lcc}
\multicolumn{1}{c}{ Variável } & $\begin{array}{c}\text { Pontos de } \\
\text { Amostragem }\end{array}$ & Freqüência das Análises \\
\hline Série Completa de Sólidos & 4 e 5 & 2 x semana \\
Sólidos Sedimentáveis 30 minutos & 4 e 5 & 1 x dia \\
Oxigênio Dissolvido & 4 e 5 & contínuo \\
$\mathrm{pH}$ & 4 e 5 & contínuo \\
Temperatura & 4 e 5 & contínuo \\
Potencial redox & 4 e 5 & contínuo \\
Microbiologia (microscopia) & 4 e 5 & 1 x semana \\
Bactérias nitrificantes & 4 e 5 & 1 x semana \\
\hline
\end{tabular}

\subsubsection{Caracterização da Biomassa}

\subsubsection{Caracterização Quantitativa da Biomassa Aderida}

Foram realizadas 5 determinações das características quantitativas da biomassa aderida. O método utilizado para extração do biofilme do meio suporte consistiu no seguinte seqüenciamento de atividades:

- Em cada determinação, foram coletados suportes plásticos do tanque de aeração, utilizando-se peneira; 
- O material coletado era transferidos para o frascos da Figura 17-a, até completar seu volume de $40 \mathrm{~mL}$ (cerca de 35 unidades), adicionando-se, em seguida, água destilada;

- Os frascos foram mantidos em vibrador durante 10 minutos para a pré-soltura do material aderido;

- O conteúdo dos frascos foi transferido para cápsulas de porcelana e cada elemento foi raspado em suas superfícies externa e interna com escova de uso odontológico (Figura 17-b);

- Ao mesmo tempo da raspagem, os suportes iam sendo lavados com água desionizada, recolhendo-se todo o volume produzido em um becker (Figura $17-c)$.

Posteriormente foram realizadas as determinações das concentrações de SSV e SST e as observações microscópicas (Figura 17-d).

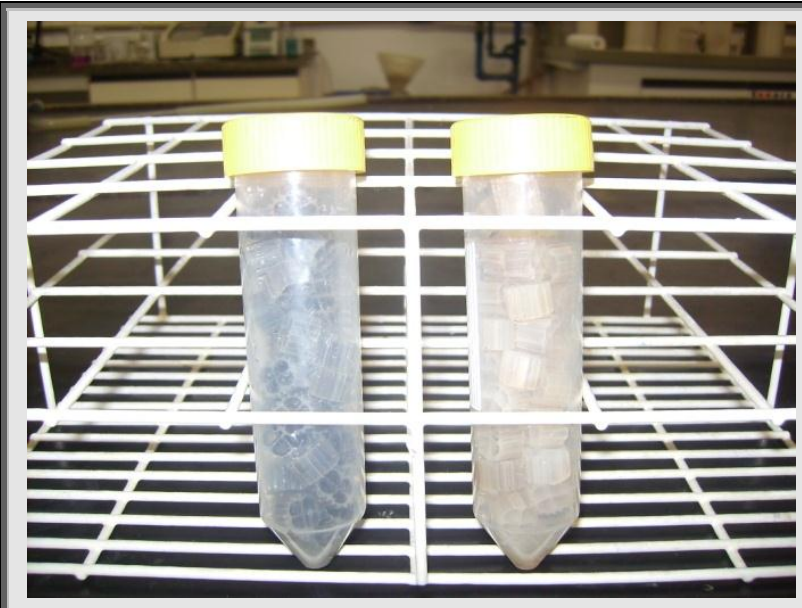

(a)

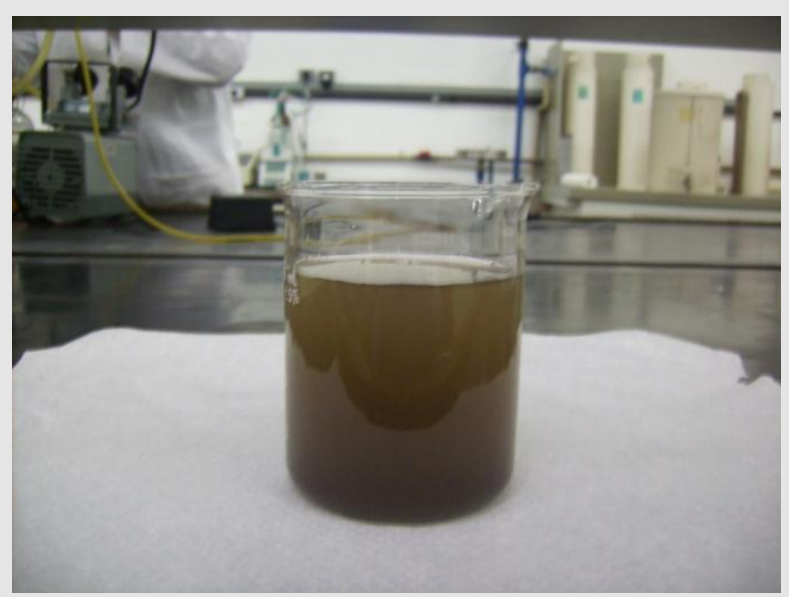

(c)

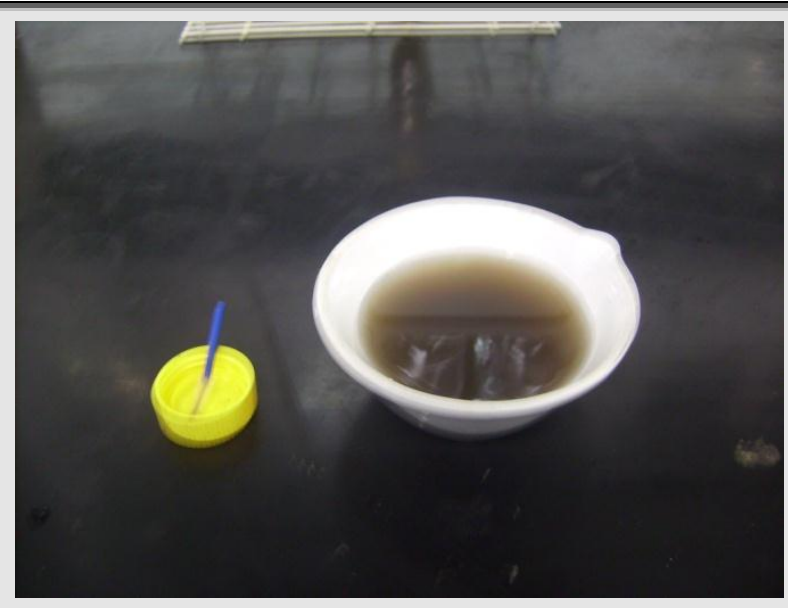

(b)

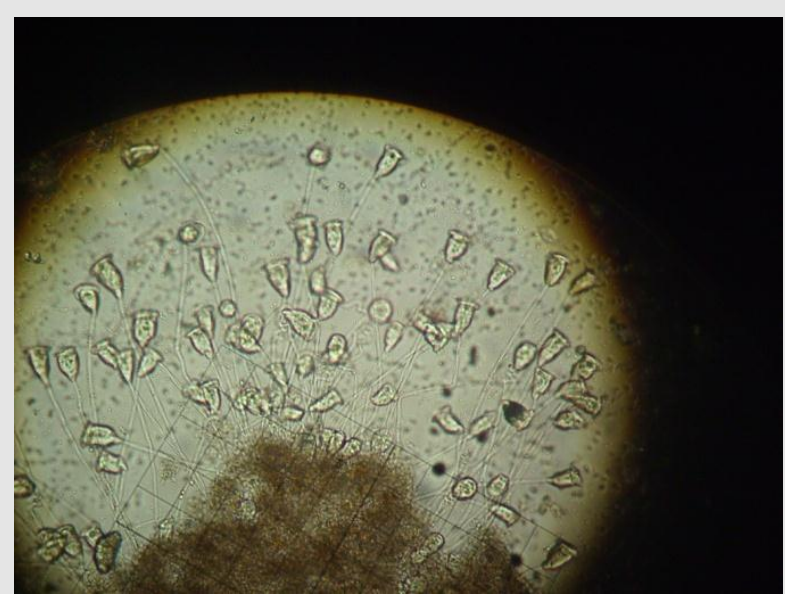

(d)

Figura 17 - Fotografias documentando o procedimento experimental para quantificação e qualificação de biomassa aderida. 


\subsubsection{Caracterização Qualitativa da Biomassa}

O método de análise da microfauna constituinte da biomassa em suspensão consistiu no procedimento descrito a seguir:

- As amostras foram retiradas dos tanques dos módulos experimentais e no laboratório foram agitadas para homogeneização do líquido;

- Subamostras foram retiradas do frasco de coleta com auxílio de pipeta automática e colocadas em câmara de Sedwick-Rafter com capacidade de 1,0 mL de volume para quantificação da diversidade biológica (Branco, 1986; CETESB, 1990);

- Foram realizadas três contagens por amostra;

- $\mathrm{Na}$ identificação da microfauna foram utilizadas chaves de classificação taxonômica e artigos científicos (Madoni, Minegatti, 2008).

Procedimento semelhante foi seguido para a microscopia das amostras de biomassa extraídas do elementos suporte, conforme descrição na seção 4.4.3.1. 


\section{RESULTADOS E DISCUSSÕES}

Os resultados obtidos são apresentados, inicialmente com a caracterização do esgoto afluente, das condições ambientais e das variáveis operacionais monitoradas e a verificação de sua conformidade. Partindo desses dados procede-se com a verificação dos valores obtidos para os parâmetros de projeto e levantamento das variáveis de controle do processo recomendados para sistemas de biomassa aderida, avaliação comparativa do desempenho dos processos e interpretação final dos resultados obtidos.

Os resultados efetivamente válidos para a pesquisa começaram a ser obtidos de forma contínua apenas no final do mês de maio de 2010. Na programação experimental inicial os dois módulos seriam submetidos a um mesmo processo evolutivo de carregamento e de condição de idade do lodo. Tomando-se por referência apenas a biomassa em suspensão, estava previsto o aumento da carga aplicada e a redução progressiva da idade do lodo, até que cessasse a nitrificação do lodo ativado, esperando-se que o mesmo não acontecesse no módulo preenchido com suportes plásticos móveis. Essa maior capacidade de receber carga orgânica e de nitrificar o esgoto no módulo com a tecnologia MBBR é atribuída à biomassa aderida a ser quantificada e qualificada mediante variáveis de natureza físico-química e biológica.

O planejamento previa duração de 10 semanas por fase e o cumprimento de uma quarta fase em que seriam praticados uma relação alimento/microorganismo de 0,5 $\mathrm{kg} \mathrm{DBO}_{5,20} / \mathrm{kg}$ SSV.d e idade do lodo referente á biomassa em suspensão de 3,7 dias. A duração prevista das fases não foi cumprida como o planejado porque, como já mencionado, optou-se para que variassem de acordo com o alcance dos desempenhos esperados especialmente em relação à remoção de nitrogênio.

A fase 1 foi a mais extensa, com duração de 15,5 semanas porque, além de se estender por um período de avanço dos sistemas para o regime permanente, coincidiu com o período de inverno no mês de Agosto em São Paulo, com temperaturas médias de $18{ }^{\circ} \mathrm{C}$ atingindo o valor mínimo de $14{ }^{\circ} \mathrm{C}$ medidos nos reatores. Quando as temperaturas se elevaram e o desempenho do sistema de lodo ativado se restabeleceu procedeu-se para a fase seguinte. 
Nessa primeira condição experimental, conforme previsto inicialmente, os dois módulos deveriam ser postos em marcha de forma a resultar em uma idade do lodo em torno de 9,3 dias. Nestas condições, o tempo de retenção de sólidos efetivo para a nitrificação do lodo ativado seria de apenas cerca de 6 dias, já que o compartimento anóxico ocupa cerca de $30 \%$ do volume útil total do tanque de aeração. Embora seja possível a obtenção da nitrificação nestas condições, tal fenômeno não ocorreu eficientemente em decorrência das baixas temperaturas.

Foi interessante a oportunidade de evidenciar a diferença entre os resultados dos dois sistemas em ambiente mais frio, uma vez que o sistema IFAS manteve a nitrificação com eficiência elevada, demonstrando de forma inequívoca o incremento na capacidade de remoção de carga e de nitrificação providenciado pela biomassa aderida.

$\mathrm{Na}$ segunda condição operacional houve menor variação das condições operacionais e os sistemas apresentaram desempenhos mais regulares e eficientes. A Fase 3 foi marcada pela operação além da capacidade do sistema de lodo ativado para a realização da nitrificação, com idade do lodo aeróbia de 3,2 dias.

As condições operacionais da quarta fase não foram estudadas por consequência de incidentes operacionais que ocorreram no final-de-ano e início do mês de Janeiro que comprometeram a manutenção da operação aceitável dos sistemas. O período de férias provoca uma diminuição drástica da vazão de esgoto do CRUSP pela evasão dos estudantes que ocupam o condomínio e parada da operação do restaurante central. O sistema de alimentação foi interrompido por diversas vezes pela total ausência de esgoto. Além da falta de substrato para os processos os motores dos raspadores dos decantadores secundários se danificaram nesse período em que não havia equipe para efetuar a sua manutenção. Por essa razão a quantidade de sólidos dos reatores diminuiu bruscamente, pois o lodo sedimentado nas paredes do decantador não era bombeado de volta para os reatores. Como resultado a nitrificação cessou no sistema IFAS. 


\subsection{Caracterização do esgoto bruto}

A composição do esgoto efluente do tratamento primário e afluente aos processos biológicos é apresentada na Tabela 8. Observa-se relativa estabilidade, especialmente por se tratar de uma fonte relativamente controlada e não receber contribuições de águas pluviais e nenhuma contribuição por infiltração. A composição do esgoto tem características domésticas, típicas do município de São Paulo, exceção feita à concentração de nitrogênio Kjieldal Total, que em média é consideravelmente maior que a esperada. Uma possível interpretação desse valor é a natureza da utilização dos sanitários do restaurante central, com contribuições predominantemente de urina.

Tabela 8 - composição do esgoto afluente ao tratamento biológico.

\begin{tabular}{lccccc}
\hline & $\begin{array}{c}\text { Número } \\
\text { de Dados }\end{array}$ & Média & Mínimo & Máximo & $\begin{array}{c}\text { Desvio } \\
\text { Padrão }\end{array}$ \\
\hline DQO total (mg/L) & 39 & 474,5 & 219,0 & 631,0 & 94,1 \\
$\mathrm{DBO}_{5,20}$ total (mg/L) & 15 & 217,1 & 71,2 & 351,6 & 71,3 \\
$\mathrm{SST}(\mathrm{mg} / \mathrm{L})$ & 43 & 118,2 & 60,0 & 234,0 & 34,8 \\
$\mathrm{SSV}(\mathrm{mg} / \mathrm{L})$ & 42 & 105,0 & 56,0 & 204,0 & 30,5 \\
$\mathrm{NKT}(\mathrm{mg} / \mathrm{L})$ & 42 & 83,0 & 11,0 & 189,0 & 25,9 \\
$\mathrm{NH} \mathrm{H}_{4} \mathrm{~N}(\mathrm{mg} / \mathrm{L})$ & 44 & 61,3 & 32,0 & 83,4 & 9,3 \\
$\mathrm{P}$ total (mg/L) & 22 & 5,8 & 3,8 & 11,0 & 1,5 \\
Alcalinidade (meq/L) & 26 & 211,5 & 150,0 & 282,0 & 30,3 \\
\hline
\end{tabular}

\subsection{Apresentação dos resultados do monitoramento}

Inicialmente, são apresentados os resultados relativos à remoção de matéria orgânica e de sólidos em suspensão, para a avaliação das condições operacionais dos processos de uma forma mais ampla. Em seguida, são apresentados os resultados relativos à remoção de nutrientes, avaliados em relação às condições operacionais impostas em cada fase e ao controle feito mediante a instalação de 
sensores nos tanques. Por fim, são apresentados os resultados correspondentes às caracterizações quantitativas e qualitativas das biomassas em suspensão e aderida presentes nos reatores biológicos, associando-os aos de remoção de nutrientes.

No presente item, 5.2 ao se referir ao sistema 2, IFAS, será utilizado o termo MBBR, usado ao longo da pesquisa para diferenciação dos dois sistemas como um nome derivado da referência à tecnologia empregada.

\subsubsection{Resultados relativos à remoção de matéria orgânica e sólidos em suspensão}

Nas Tabelas 9, 10 e 11 são apresentados os resultados correspondentes às fases 1 , 2 e 3, respectivamente, da estatística descritiva dos resultados de DQO total e filtrada do afluente e dos efluentes dos processos de lodo ativado e MBBR. Esses resultados são comparados sob a forma de gráficos de séries históricas (médias móveis de 4 determinações) e Diagramas Box-Whiskers nas Figuras 18 a 23.

Tabela 9 - Resultados da estatística descritiva dos resultados de DQO total e filtrada do afluente e dos efluentes dos processos de lodo ativado e MBBR - Fase 1

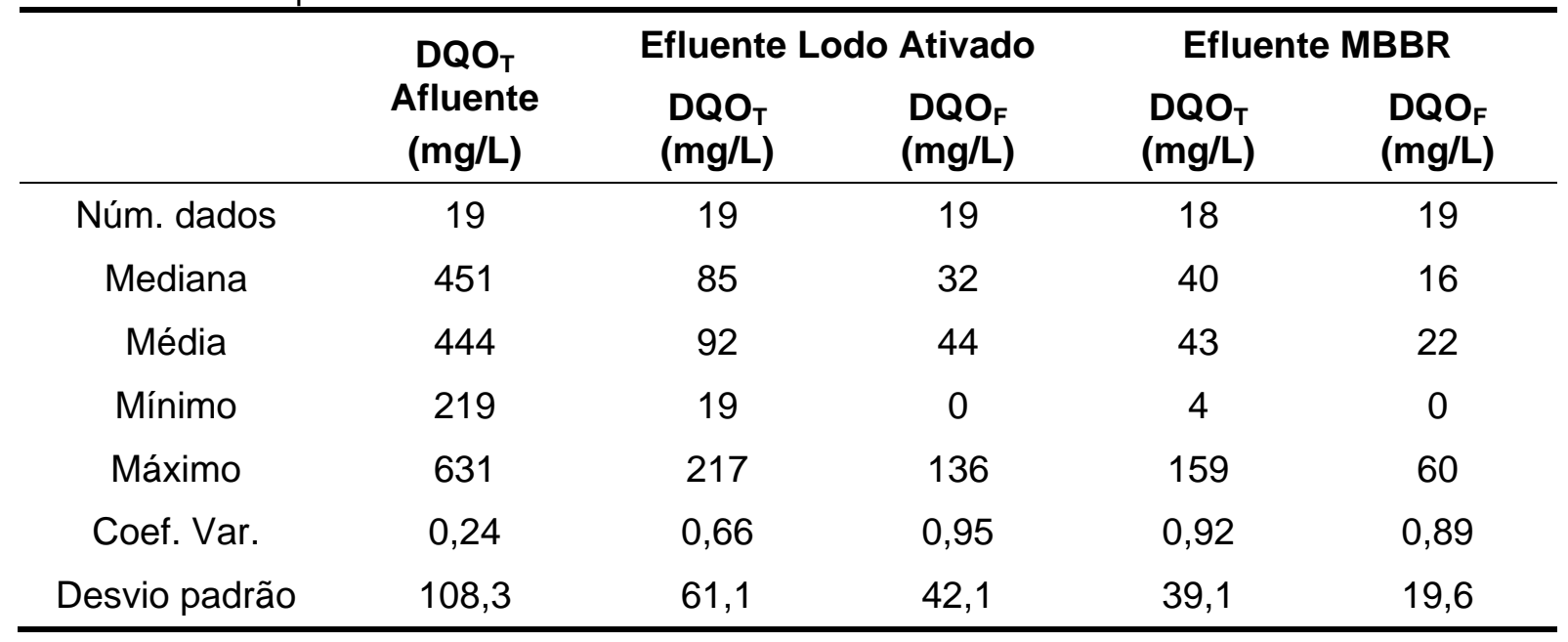

Pode-se afirmar, com base nos dados das Tabelas 9, 10 e 11 que ambos os processos foram mantidos sob operação estável e eficiente quanto à remoção de matéria orgânica durante as três fases. Nas séries históricas observa-se que o afluente manteve-se relativamente estável, sendo que os efluentes apresentaram ligeira elevação de concentração no final dos três períodos. Nos Diagramas BoxWhiskers verifica-se que a eficiência do MBBR foi mais elevada que a do lodo ativado na fase 1 e mantiveram-se equivalentes nas outras duas fases. 
Tabela 10 - Resultados da estatística descritiva dos resultados de DQO total e filtrada do afluente e dos efluentes dos processos de lodo ativado e MBBR - Fase 2

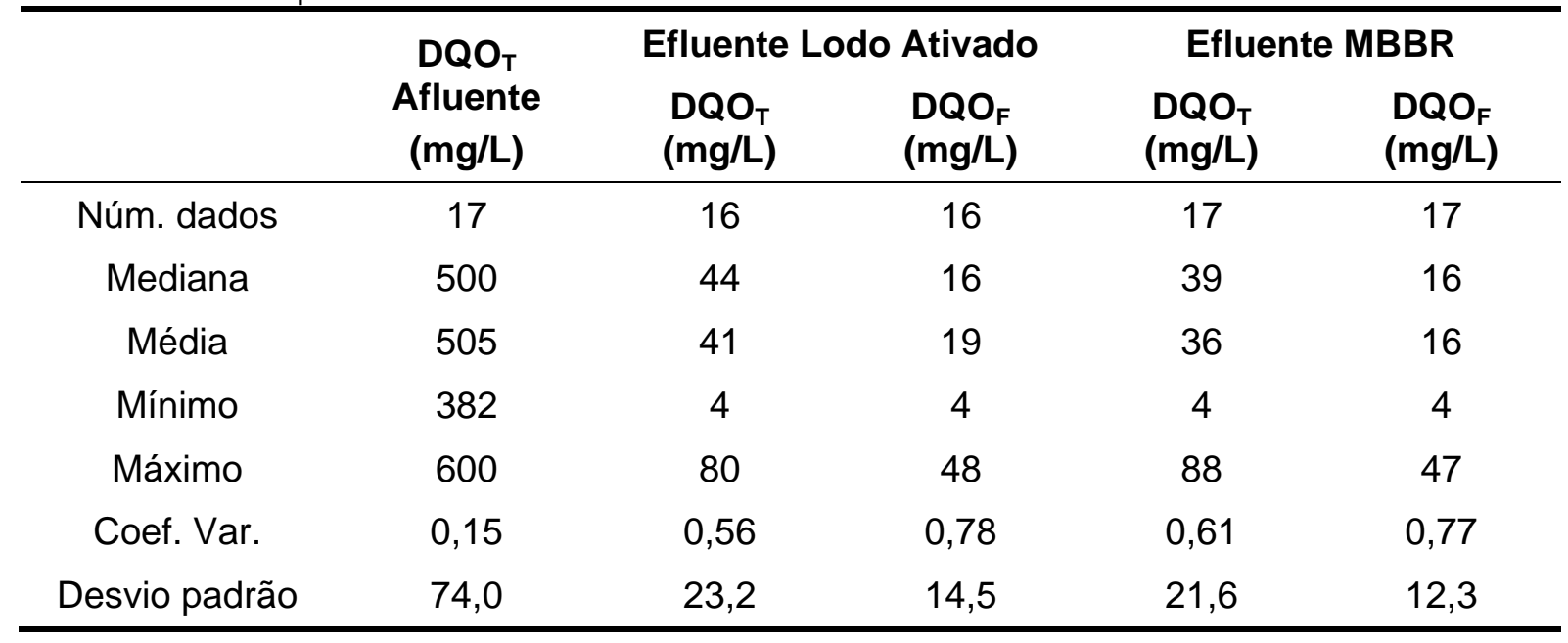

Tabela 11 - Resultados da estatística descritiva dos resultados de DQO total e filtrada do afluente e dos efluentes dos processos de lodo ativado e MBBR - Fase 3

\begin{tabular}{|c|c|c|c|c|c|}
\hline & \multirow{2}{*}{$\begin{array}{c}\mathrm{DQO}_{\mathrm{T}} \\
\text { Afluente } \\
\text { (mg/L) }\end{array}$} & \multicolumn{2}{|c|}{ Efluente Lodo Ativado } & \multicolumn{2}{|c|}{ Efluente MBBR } \\
\hline & & $\begin{array}{c}\mathrm{DQO}_{\mathrm{T}} \\
(\mathrm{mg} / \mathrm{L})\end{array}$ & $\begin{array}{c}\mathrm{DQO}_{\mathrm{F}} \\
(\mathrm{mg} / \mathrm{L})\end{array}$ & $\begin{array}{c}\mathrm{DQO}_{\mathrm{T}} \\
(\mathrm{mg} / \mathrm{L})\end{array}$ & $\begin{array}{c}\mathrm{DQO}_{\mathrm{F}} \\
(\mathrm{mg} / \mathrm{L})\end{array}$ \\
\hline Núm. dados & 3 & 3 & 3 & 3 & 3 \\
\hline Mediana & 505 & 83 & 53 & 75 & 44 \\
\hline Média & 495 & 83 & 50 & 93 & 50 \\
\hline Mínimo & 460 & 64 & 32 & 60 & 44 \\
\hline Máximo & 521 & 101 & 67 & 145 & 63 \\
\hline Coef. Var. & 0,06 & 0,22 & 0,35 & 0,49 & 0,21 \\
\hline Desvio padrão & 31,6 & 18,6 & 17,4 & 45,4 & 10,7 \\
\hline
\end{tabular}

Em termos da DQO de amostras filtradas, na fase 1 observam-se valores baixos nos efluentes, sobretudo no do MBBR, demonstrando efetiva remoção de matéria coloidal do esgoto e ocorrência de perda de matéria orgânica particulada com os efluentes tratados de forma a dobrar, aproximadamente, o valor da DQO total dos efluentes. Na segunda fase o lodo ativado mostrou melhora significativa, se equiparando com o desempenho do MBBR como indicativo de pleno desenvolvimento de sua atividade microbiológica, apresentando boa formação de flocos. As condições de carregamento da fase 3 provocaram o declínio das eficiências do sistema de lodo ativado, mas ainda com bons resultados. $\mathrm{O}$ aumento da DQO no efluente do MBBR é em sua maior parte de material não biodegradável, se forem observados os resultados de DBO a seguir. 


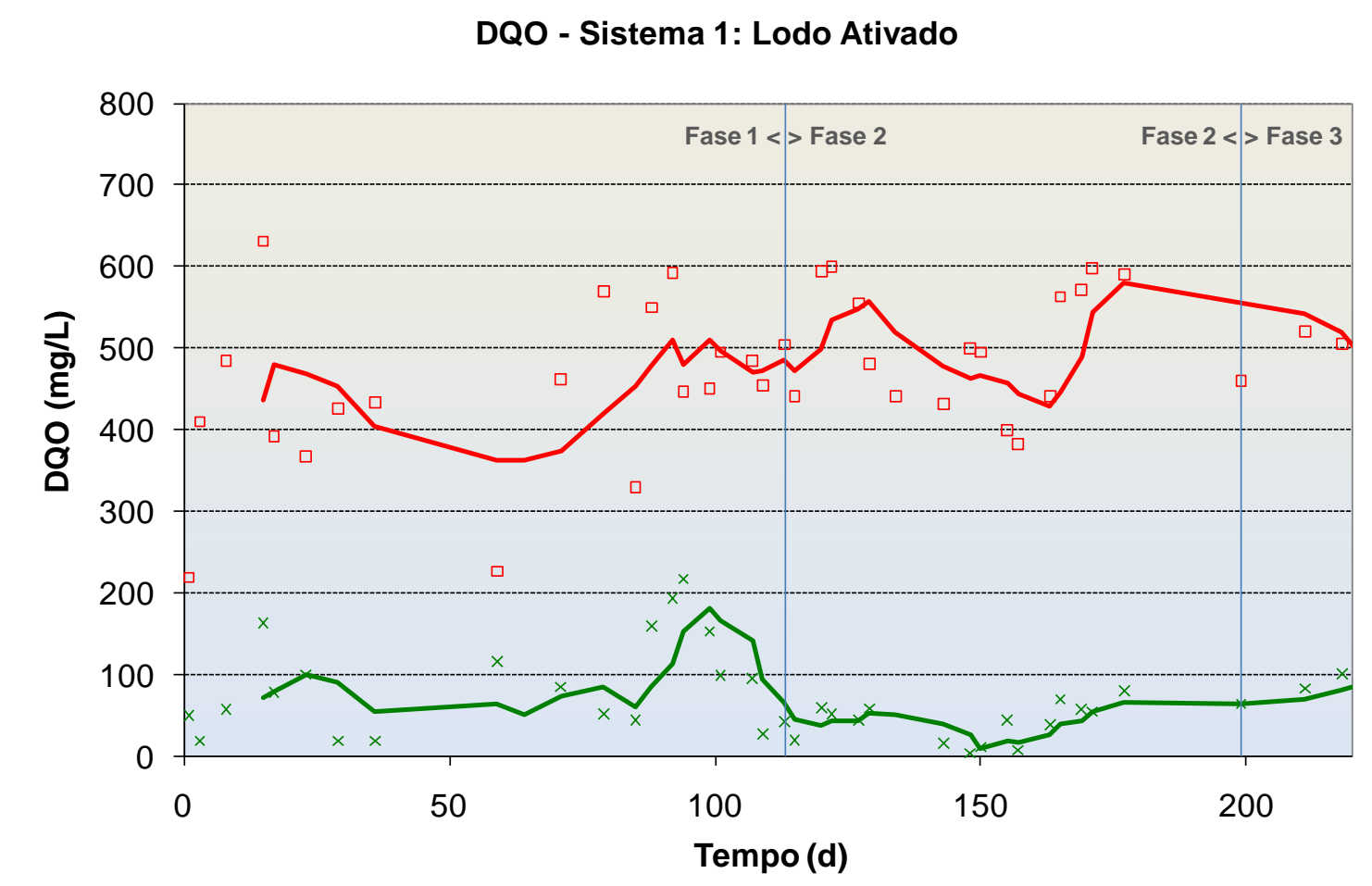

$\square$ Afluente $\times$ Efluente $\longrightarrow 4$ por Média Móvel(Afluente) —4 por Média Móvel(Efluente)

Figura 18 - Série histórica - DQO total - Sistema 1: Lodo Ativado

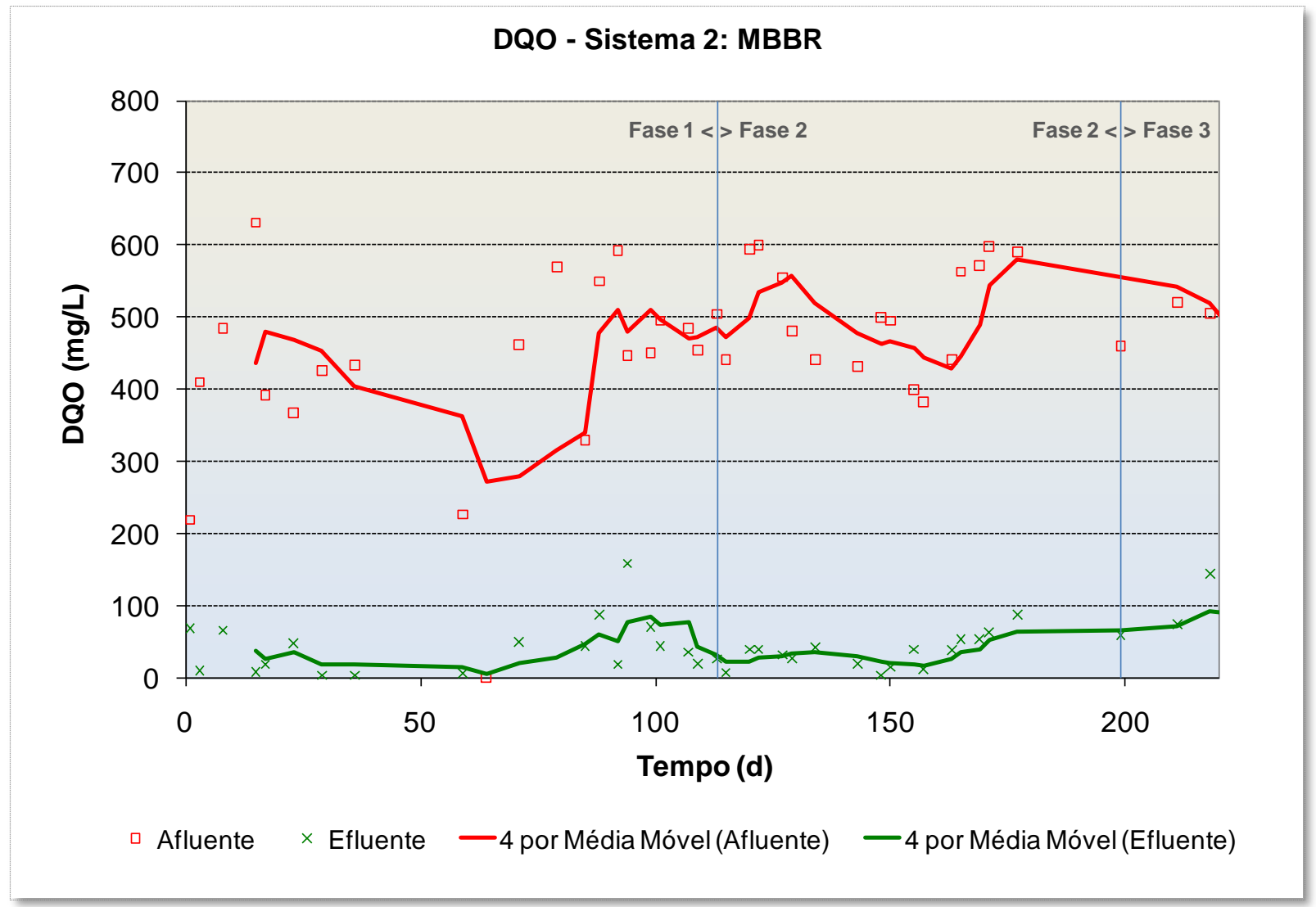

Figura 19 - Série histórica - DQO total - Sistema 2: MBBR 


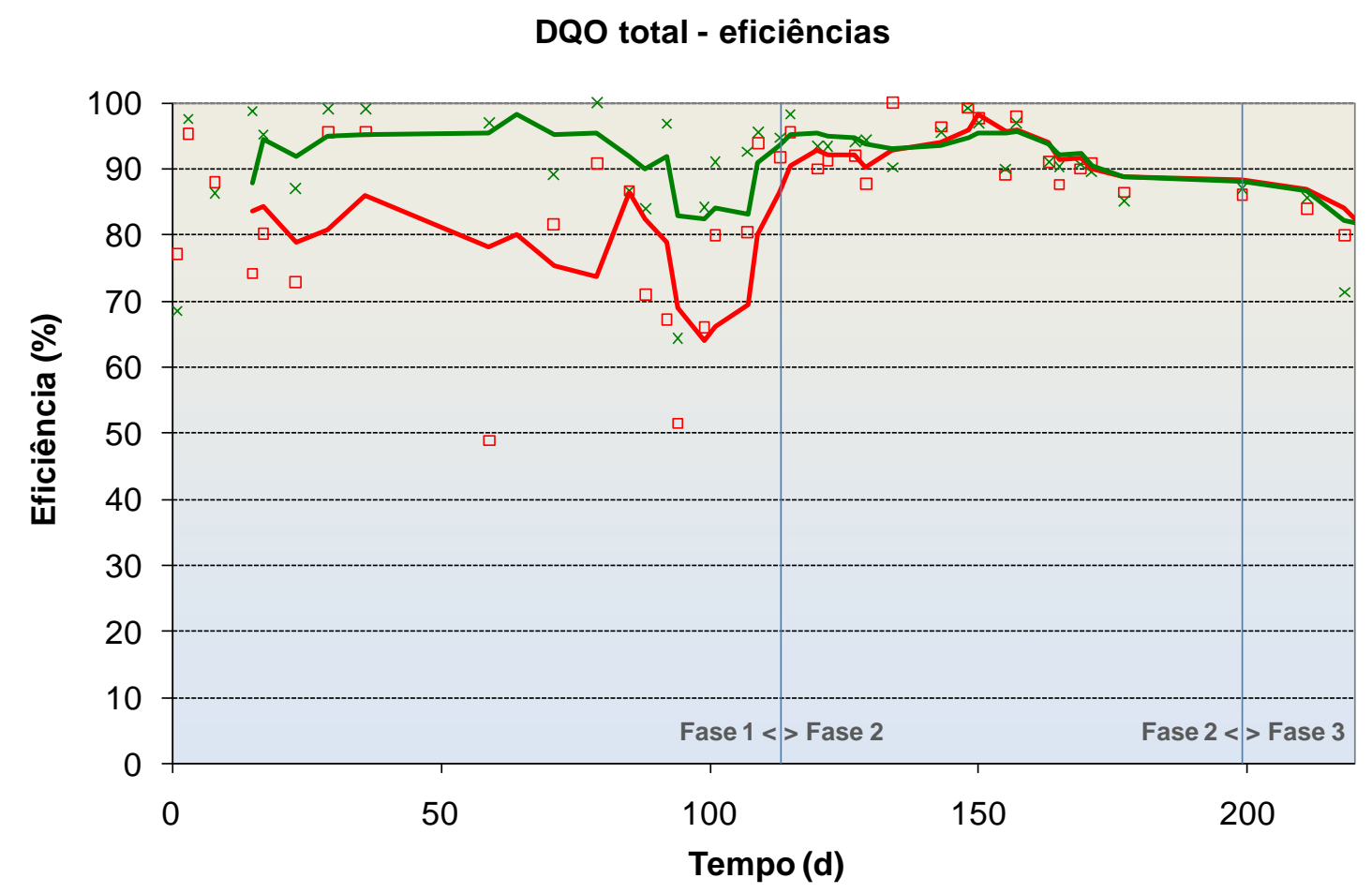

$\square$ DQO total LA $\times$ DQO total MBBR —4 por Média Móvel (DQO total LA) — 4 por Média Móvel (DQO total MBBR)

Figura 20 - Série histórica - DQO total - Eficiências

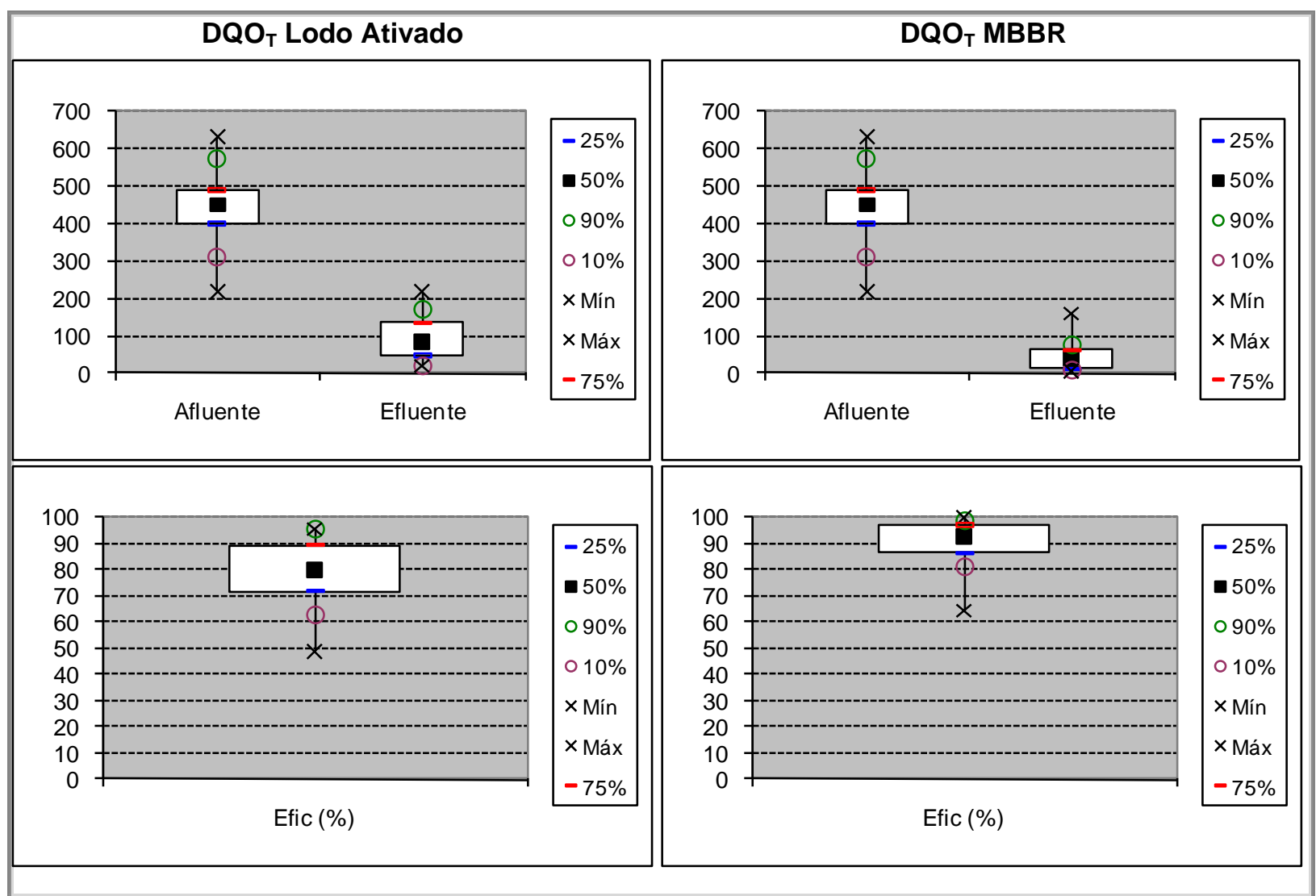

Figura 21 - Diagramas Box-Whiskers - Resultados de DQO total - Fase 1 


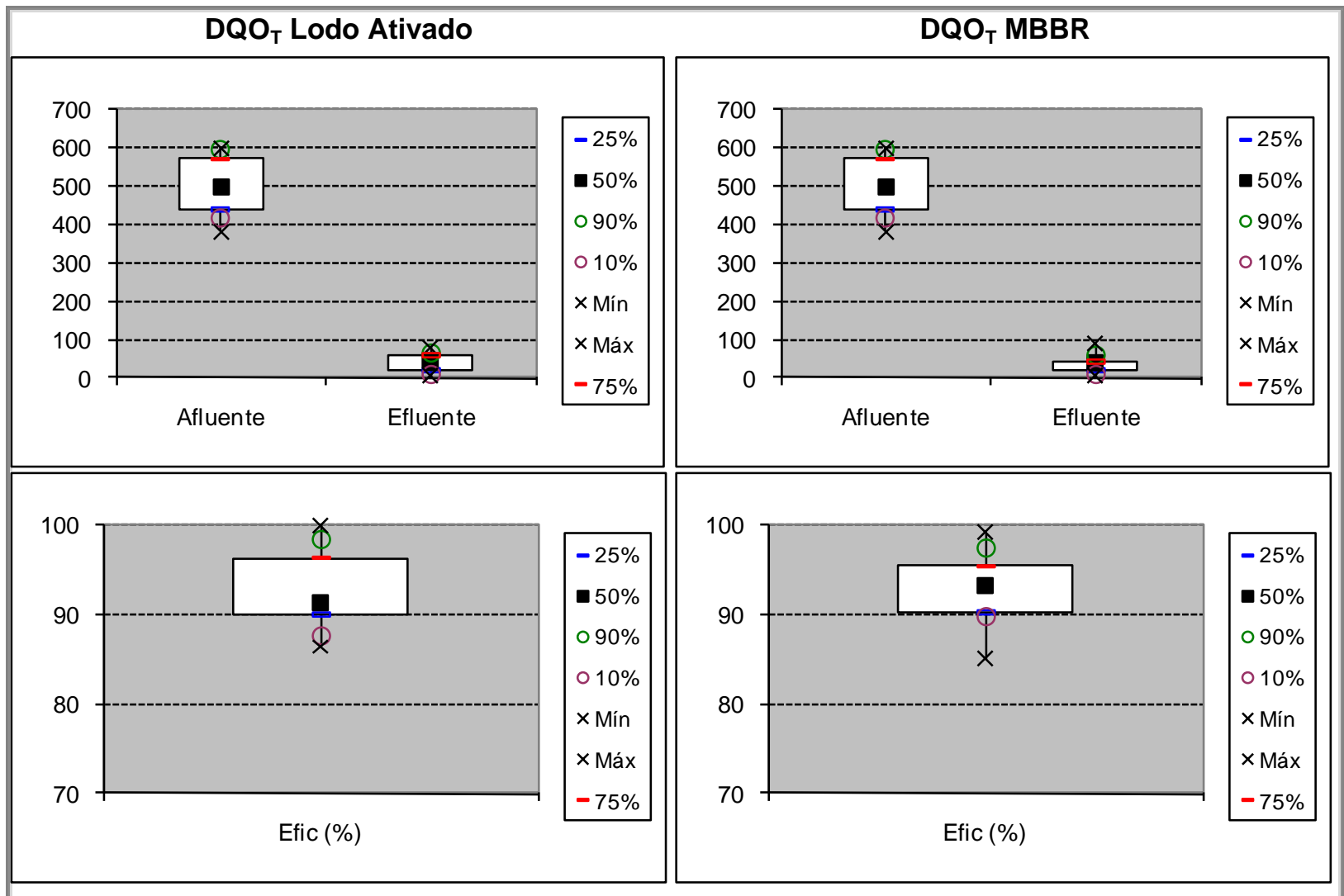

Figura 22 - Diagramas Box-Whiskers - Resultados de DQO total - Fase 2

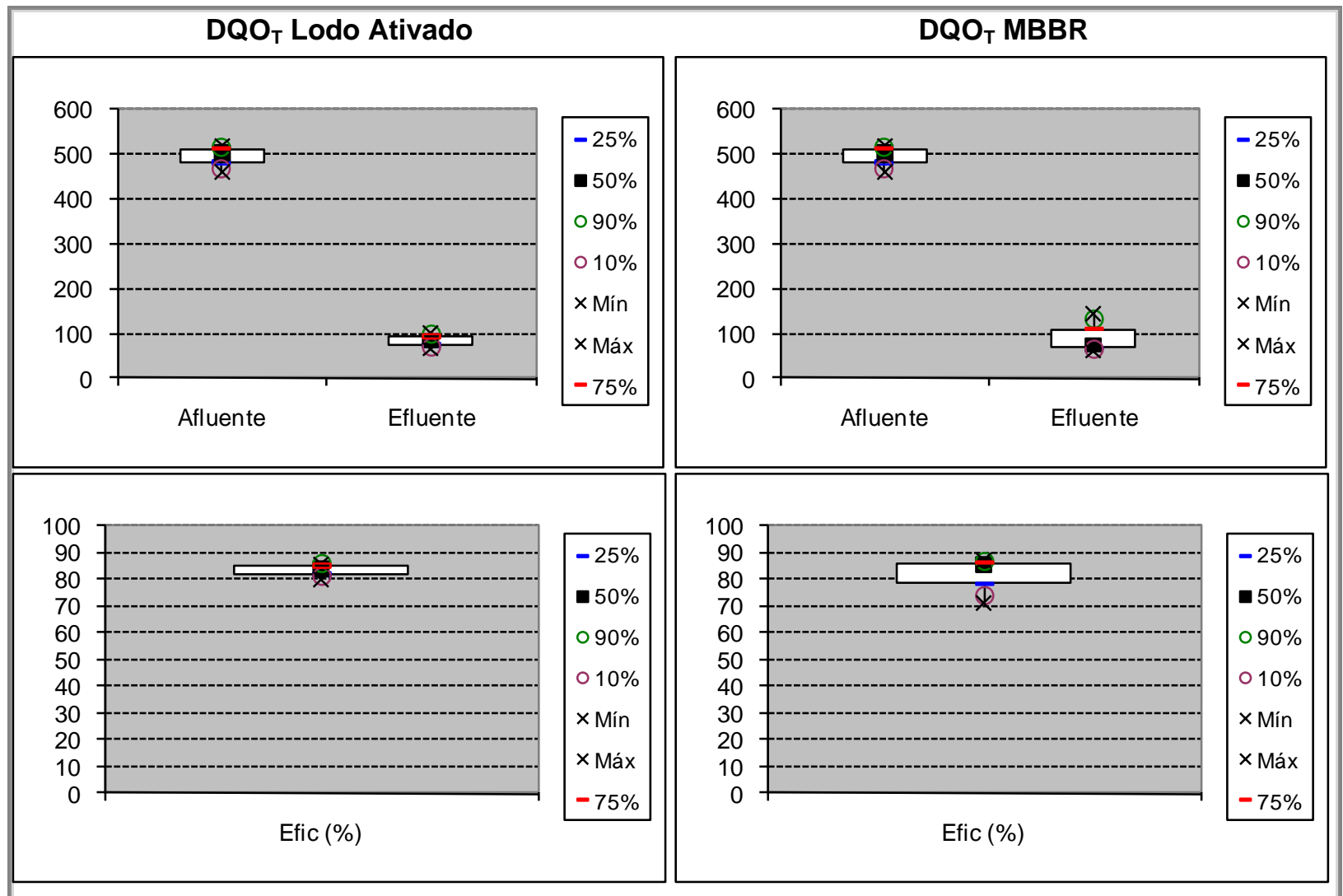

Figura 23 - Diagramas Box-Whiskers - Resultados de DQO total - Fase 3 
Nas Tabelas 12, 13 e 14 são apresentados os resultados de DBO. Os resultados da fase 1 denotam que o processo de lodo ativado removeu matéria orgânica biodegradável abaixo do que poderia ser esperado, motivado pela velocidade relativamente alta do raspador de lodo do decantador secundário. Esta constatação pode ser fundamentada na diferença entre os resultados de DBO total e filtrada. Ressalta-se que a perda de sólidos com o efluente final foi considerada na determinação da quantidade de lodo a ser diariamente retirada do processo para controle da idade do lodo. $\mathrm{Na}$ fase 2 a eficiência do lodo ativado melhorou devido à estabilidade que o sistema consolidou nesse período. Na fase 3 voltou a se agravar o problema de perda de sólidos no efluente do decantador secundário do sistema de lodo ativado. O MBBR, entretanto, mostrou uma eficiência altíssima nesse período.

Tabela 12 - Resultados da estatística descritiva dos resultados de DBO total e filtrada do afluente e dos efluentes dos processos de lodo ativado e MBBR - Fase 1

\begin{tabular}{|c|c|c|c|c|c|}
\hline & \multirow{2}{*}{$\begin{array}{c}\mathrm{DBO}_{\mathrm{T}} \\
\text { Afluente } \\
\text { (mg/L) }\end{array}$} & \multicolumn{2}{|c|}{ Efluente Lodo Ativado } & \multicolumn{2}{|c|}{ Efluente MBBR } \\
\hline & & $\begin{array}{c}\mathrm{DBO}_{\mathrm{T}} \\
\text { (mg/L) }\end{array}$ & $\begin{array}{c}\mathrm{DBO}_{\mathrm{F}} \\
(\mathrm{mg} / \mathrm{L})\end{array}$ & $\begin{array}{c}\mathrm{DBO}_{\mathrm{T}} \\
(\mathrm{mg} / \mathrm{L})\end{array}$ & $\begin{array}{l}\mathrm{DBO}_{\mathrm{F}} \\
(\mathrm{mg} / \mathrm{L})\end{array}$ \\
\hline Núm. dados & 8 & 8 & 8 & 8 & 8 \\
\hline Mediana & 206 & 71 & 17 & 19 & 10 \\
\hline Média & 214 & 67 & 23 & 25 & 12 \\
\hline Mínimo & 71 & 28 & 9 & 8 & 3 \\
\hline Máximo & 352 & 97 & 47 & 61 & 25 \\
\hline Coef. Var. & 0,38 & 0,39 & 0,57 & 0,72 & 0,68 \\
\hline Desvio padrão & 81,5 & 26,3 & 12,9 & 17,9 & 7,9 \\
\hline
\end{tabular}

Tabela 13 - Resultados da estatística descritiva dos resultados de DBO total e filtrada do afluente e dos efluentes dos processos de lodo ativado e MBBR - Fase 2

\begin{tabular}{|c|c|c|c|c|c|}
\hline & \multirow{2}{*}{$\begin{array}{c}\text { DBO }_{\mathrm{T}} \\
\text { Afluente } \\
\text { (mg/L) }\end{array}$} & \multicolumn{2}{|c|}{ Efluente Lodo Ativado } & \multicolumn{2}{|c|}{ Efluente MBBR } \\
\hline & & $\begin{array}{c}\mathrm{DBO}_{\mathrm{T}} \\
(\mathrm{mg} / \mathrm{L})\end{array}$ & $\begin{array}{c}\mathrm{DBO}_{\mathrm{F}} \\
(\mathrm{mg} / \mathrm{L})\end{array}$ & $\begin{array}{c}\mathrm{DBO}_{\mathrm{T}} \\
\text { (mg/L) }\end{array}$ & $\begin{array}{c}\mathrm{DBO}_{\mathrm{F}} \\
(\mathrm{mg} / \mathrm{L})\end{array}$ \\
\hline Núm. dados & 5 & 5 & 5 & 5 & 5 \\
\hline Mediana & 244 & 43 & 15 & 23 & 10 \\
\hline Média & 236 & 44 & 14 & 32 & 11 \\
\hline Mínimo & 156 & 24 & 5 & 17 & 6 \\
\hline Máximo & 322 & 65 & 20 & 63 & 19 \\
\hline Coef. Var. & 0,28 & 0,33 & 0,41 & 0,60 & 0,51 \\
\hline Desvio padrão & 66,5 & 14,7 & 5,8 & 18,9 & 5,4 \\
\hline
\end{tabular}


Tabela 14 - Resultados da estatística descritiva dos resultados de DBO total e filtrada do afluente e dos efluentes dos processos de lodo ativado e MBBR - Fase 3

\begin{tabular}{|c|c|c|c|c|c|}
\hline & \multirow{2}{*}{$\begin{array}{c}\text { DBO }_{\top} \\
\text { Afluente } \\
\text { (mg/L) }\end{array}$} & \multicolumn{2}{|c|}{ Efluente Lodo Ativado } & \multicolumn{2}{|c|}{ Efluente MBBR } \\
\hline & & $\begin{array}{c}\mathrm{DBO}_{\top} \\
(\mathrm{mg} / \mathrm{L})\end{array}$ & $\begin{array}{c}\mathrm{DBO}_{\mathrm{F}} \\
(\mathrm{mg} / \mathrm{L})\end{array}$ & $\begin{array}{c}\mathrm{DBO}_{\mathrm{T}} \\
(\mathrm{mg} / \mathrm{L})\end{array}$ & $\begin{array}{l}\mathrm{DBO}_{\mathrm{F}} \\
(\mathrm{mg} / \mathrm{L})\end{array}$ \\
\hline Núm. dados & 2 & 2 & 2 & 2 & 2 \\
\hline Mediana & 183 & 84 & 12 & 15 & 3 \\
\hline Média & 183 & 84 & 12 & 15 & 3 \\
\hline Mínimo & 147 & 42 & 8 & 1 & 1 \\
\hline Máximo & 219 & 126 & 17 & 28 & 5 \\
\hline Coef. Var. & 0,28 & 0,71 & 0,51 & 1,34 & 1,07 \\
\hline Desvio padrão & 51,2 & 59,5 & 6,4 & 19,4 & 3,2 \\
\hline
\end{tabular}

Tabela 15 - Concentrações de sólidos em suspensão totais e voláteis no afluente e efluentes finais Fase 1

\begin{tabular}{ccccccc}
\hline & \multicolumn{2}{c}{ Afluente } & \multicolumn{2}{c}{ Efluente Lodo Ativado } & \multicolumn{2}{c}{ Efluente MBBR } \\
& $\begin{array}{c}\text { SST } \\
(\mathbf{m g} / \mathbf{L})\end{array}$ & $\begin{array}{c}\text { SSV } \\
(\mathbf{m g} / \mathbf{L})\end{array}$ & $\begin{array}{c}\mathbf{S S T} \\
(\mathbf{m g} / \mathbf{L})\end{array}$ & $\begin{array}{c}\mathbf{S S V} \\
(\mathbf{m g} / \mathbf{L})\end{array}$ & $\begin{array}{c}\mathbf{S S T} \\
(\mathbf{m g} / \mathbf{L})\end{array}$ & $\begin{array}{c}\mathbf{S S S V} \\
(\mathbf{m g} / \mathbf{L})\end{array}$ \\
\hline Núm. dados & 23 & 22 & 23 & 22 & 23 & 22 \\
Mediana & 116 & 105 & 24 & 22 & 16 & 12 \\
Média & 123 & 111 & 32 & 28 & 20 & 15 \\
Mínimo & 60 & 56 & 5 & 2 & 0 & 0 \\
Máximo & 234 & 204 & 76 & 66 & 64 & 34 \\
Coef. Var. & 0,35 & 0,34 & 0,70 & 0,75 & 0,71 & 0,61 \\
Desvio padrão & 42,8 & 37,5 & 22,4 & 20,8 & 14,5 & 9,1 \\
\hline
\end{tabular}

Tabela 16 - Concentrações de sólidos em suspensão totais e voláteis no afluente e efluentes finais Fase 2

\begin{tabular}{ccccccc}
\hline & \multicolumn{2}{c}{ Afluente } & \multicolumn{2}{c}{ Efluente Lodo Ativado } & \multicolumn{2}{c}{ Efluente MBBR } \\
& $\begin{array}{c}\text { SST } \\
(\mathbf{m g} / \mathbf{L})\end{array}$ & $\begin{array}{c}\mathbf{S S V} \\
(\mathbf{m g} / \mathbf{L})\end{array}$ & $\begin{array}{c}\mathbf{S S T} \\
(\mathbf{m g} / \mathbf{L})\end{array}$ & $\begin{array}{c}\mathbf{S S V} \\
(\mathbf{m g} / \mathbf{L})\end{array}$ & $\begin{array}{c}\mathbf{S S T} \\
(\mathbf{m g} / \mathbf{L})\end{array}$ & $\begin{array}{c}\mathbf{S S V} \\
\mathbf{( m g / L )}\end{array}$ \\
\hline Núm. dados & 17 & 17 & 17 & 17 & 17 & 17 \\
Mediana & 114 & 98 & 22 & 17 & 24 & 15 \\
Média & 116 & 102 & 23 & 18 & 22 & 16 \\
Mínimo & 72 & 70 & 0 & 0 & 6 & 1 \\
Máximo & 148 & 130 & 40 & 38 & 35 & 33 \\
Coef. Var. & 0,18 & 0,19 & 0,48 & 0,59 & 0 & 0,50 \\
Desvio padrão & 21,2 & 18,9 & 10,8 & 10,8 & 8,0 & 7,9 \\
\hline
\end{tabular}


Tabela 17 - Concentrações de sólidos em suspensão totais e voláteis no afluente e efluentes finais Fase 3

\begin{tabular}{|c|c|c|c|c|c|c|}
\hline & \multicolumn{2}{|c|}{ Afluente } & \multicolumn{2}{|c|}{ Efluente Lodo Ativado } & \multicolumn{2}{|c|}{ Efluente MBBR } \\
\hline & $\begin{array}{c}\text { SST } \\
\text { (mg/L) }\end{array}$ & $\underset{(m g / L)}{S S V}$ & $\begin{array}{c}\mathrm{SST} \\
(\mathrm{mg} / \mathrm{L})\end{array}$ & $\begin{array}{c}\text { SSV } \\
\text { (mg/L) }\end{array}$ & $\underset{(\mathrm{mg} / \mathrm{L})}{\mathrm{SST}}$ & $\underset{(\mathrm{mg} / \mathrm{L})}{\mathrm{SSV}}$ \\
\hline Núm. dados & 3 & 3 & 3 & 3 & 3 & 3 \\
\hline Mediana & 84 & 76 & 34 & 31 & 10 & 9 \\
\hline Média & 89 & 82 & 28 & 25 & 16 & 14 \\
\hline Mínimo & 82 & 72 & 12 & 11 & 9 & 7 \\
\hline Máximo & 100 & 98 & 39 & 33 & 28 & 27 \\
\hline Coef. Var. & 0,11 & 0,17 & 0,51 & 0,49 & 0,68 & 0,77 \\
\hline Desvio padrão & 9,9 & 14,0 & 14,4 & 12,2 & 10,7 & 11,0 \\
\hline
\end{tabular}

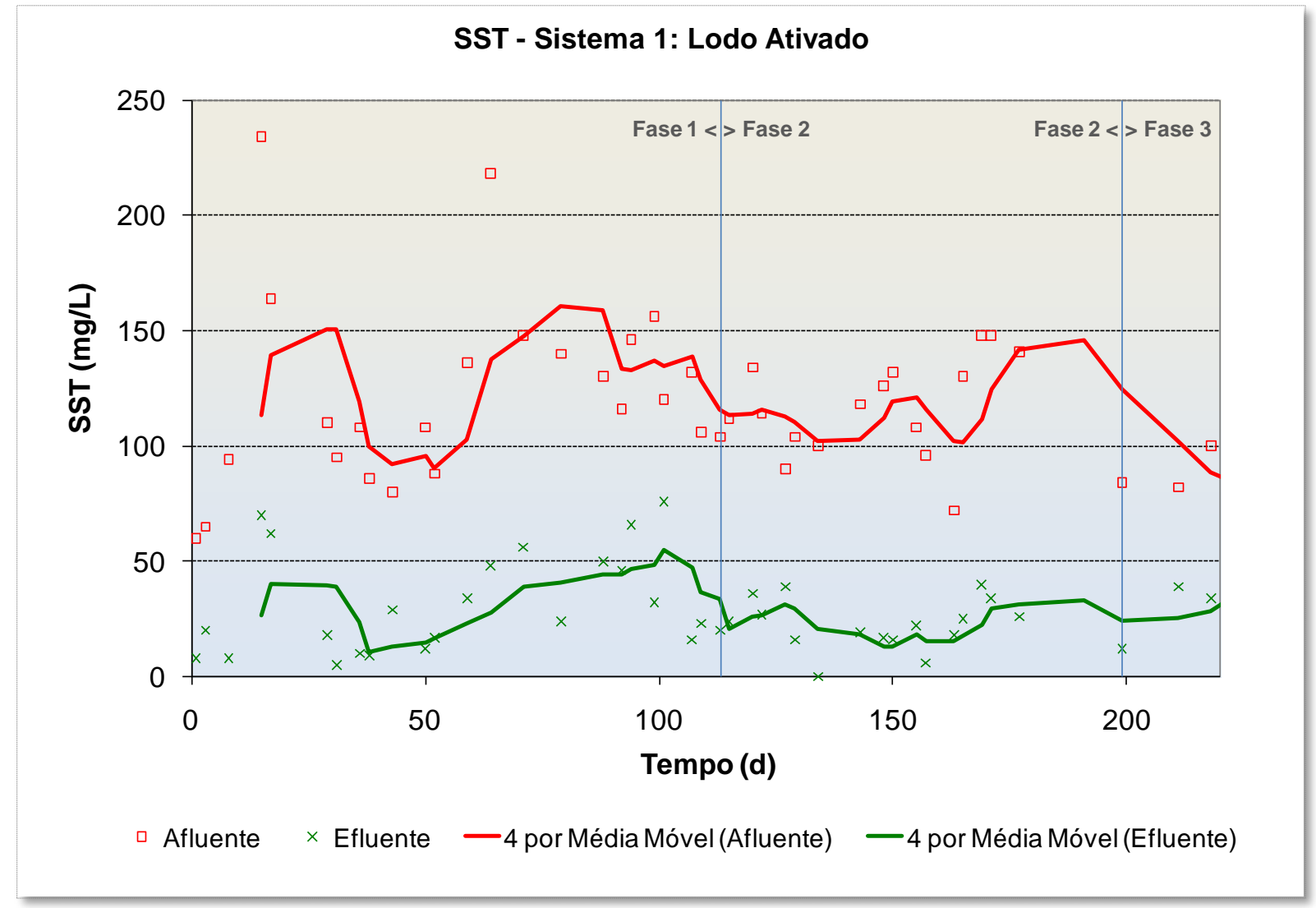

Figura 24 - Concentrações de sólidos em suspensão totais no afluente e efluentes - Lodo Ativado

Nas Tabelas 15, 16 e 17 foram apresentados os resultados de sólidos em suspensão totais e voláteis no esgoto afluente e nos efluentes finais. Os resultados de SST são lançados em gráfico nas Figuras 24 a 29. 


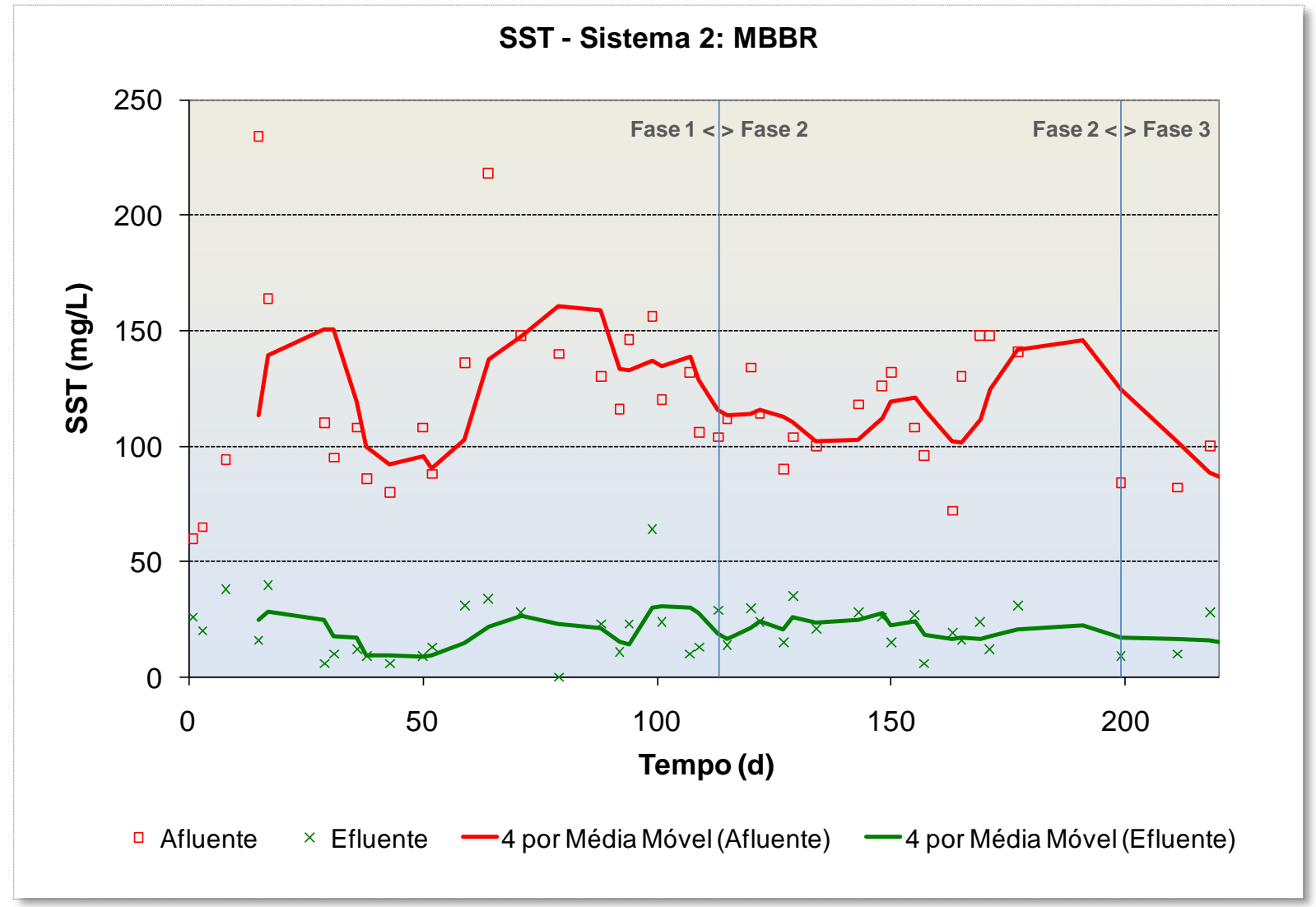

Figura 25 - Concentrações de sólidos em suspensão totais no afluente e efluentes - MBBR SST - eficiências

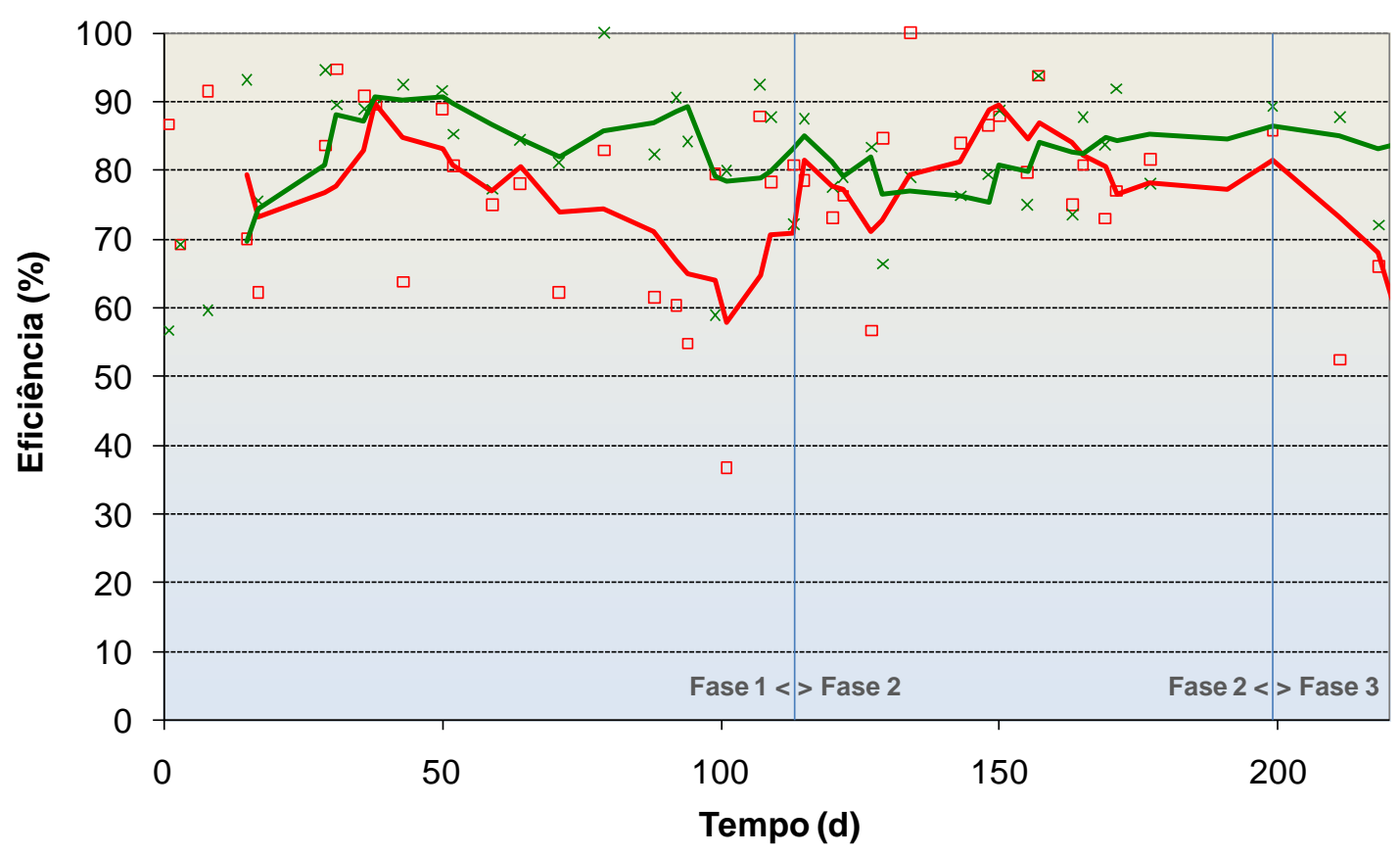

- SST LA $\times$ SST MBBR —4 por Média Móvel(SST LA) — 4 por Média Móvel (SST MBBR)

Figura 26 - Eficiências na remoção de sólidos em suspensão totais 


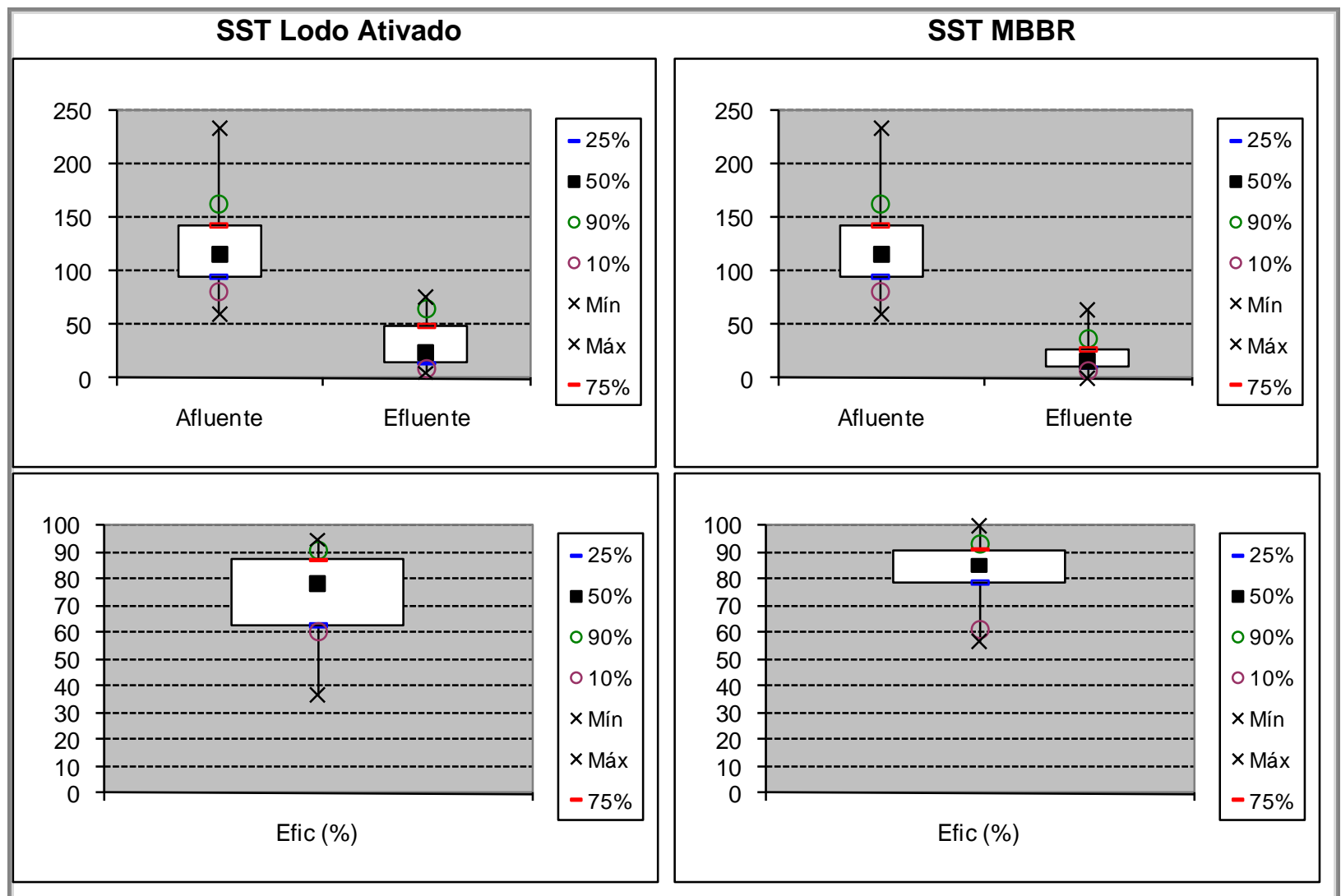

Figura 27 - Diagramas Box-Whiskers - sólidos em suspensão totais - Fase 1

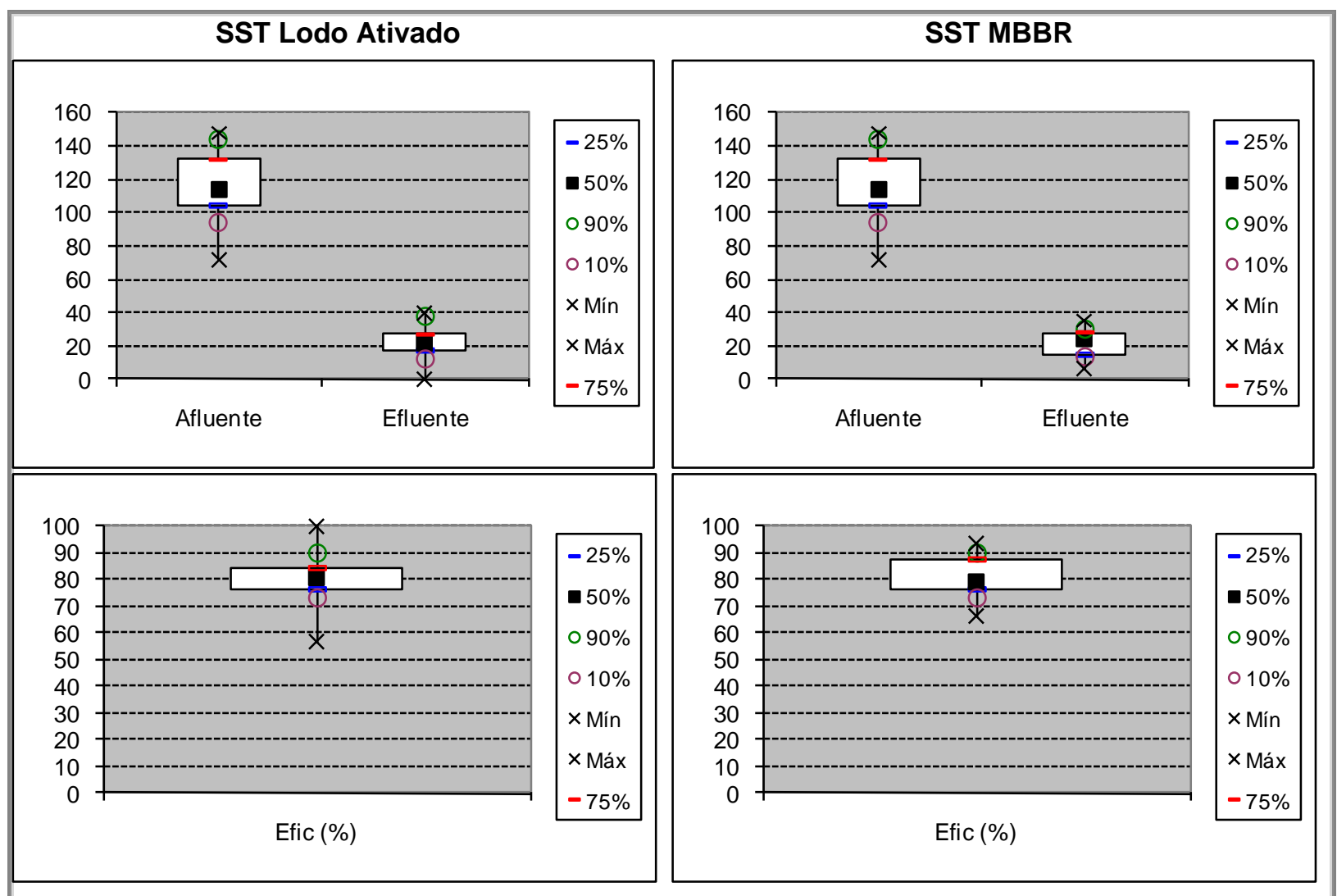

Figura 28 - Diagramas Box-Whiskers - sólidos em suspensão totais - Fase 2 


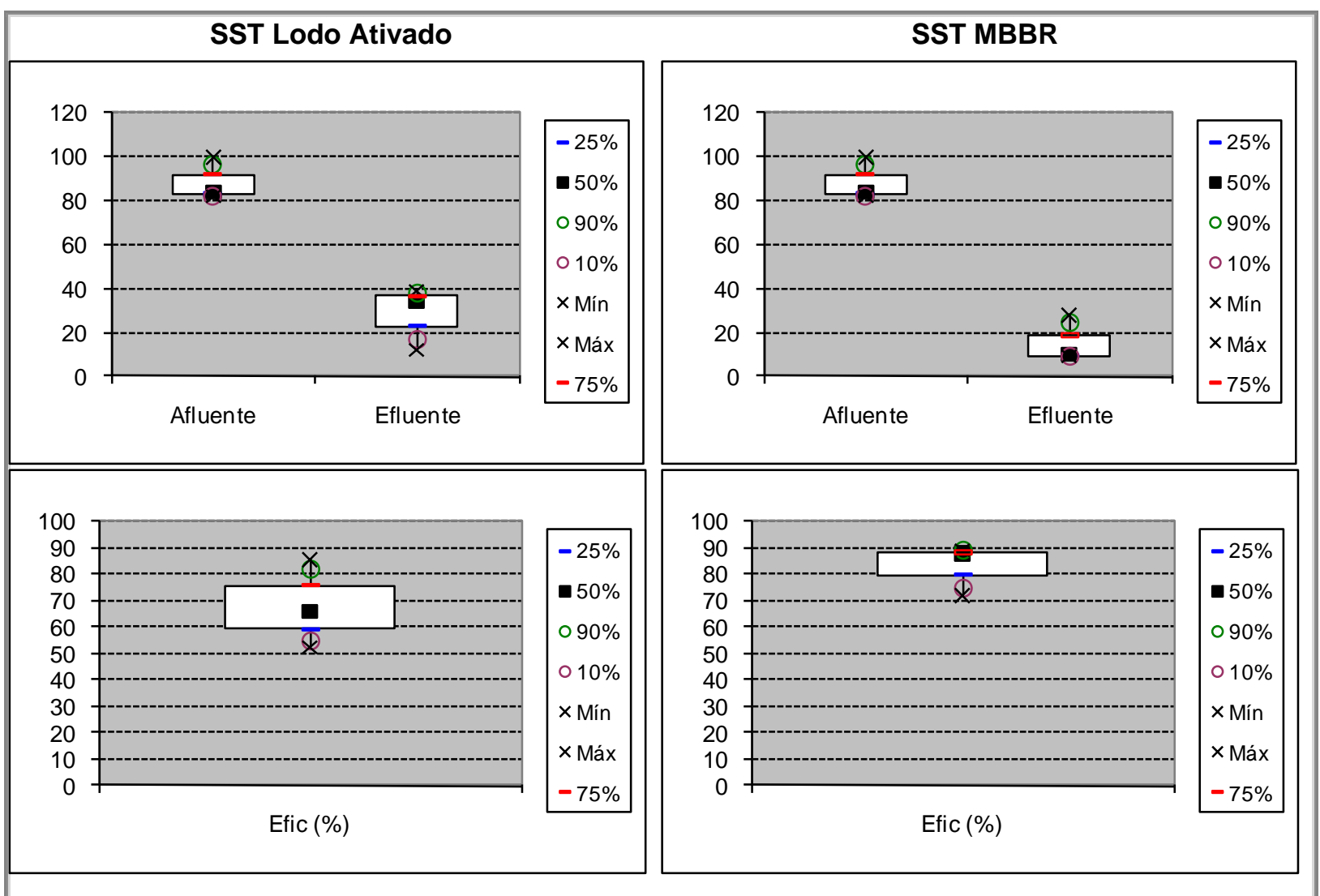

Figura 29 - Diagramas Box-Whiskers - sólidos em suspensão totais - Fase 3

Os resultados de SST confirmam o maior arraste de sólidos no efluente do lodo ativado e elevado percentual de matéria volátil na primeira fase. O desempenho de ambos os sistemas melhorou nas fases seguintes. Considerando os resultados das análises de sólidos em suspensão pode ser verificado que grande parte da DQO do efluente dos sistemas corresponde a material solúvel e não biodegradável.

\subsubsection{Resultados relativos à remoção de compostos nitrogenados}

Os resultados das medidas de concentração de Nitrogênio Total Kjeldahl no afluente e efluentes são apresentados nas Tabelas 18, 19 e 20 e lançados em gráfico nas Figuras 30 a 34. Os resultados de Nitrogênio Amoniacal são lançados em gráfico nas Figuras 35 a 39. 
Tabela 18 - Resultados de NKT e $\mathrm{NH}_{3}-\mathrm{N}$ no afluente e efluentes finais - Fase 1

\begin{tabular}{ccccccc}
\hline & \multicolumn{2}{c}{ Afluente } & \multicolumn{2}{c}{ Efluente Lodo Ativado } & \multicolumn{2}{c}{ Efluente $\mathbf{M B B R}$} \\
& $\begin{array}{c}\mathbf{N K T} \\
(\mathbf{m g N} / \mathbf{L})\end{array}$ & $\begin{array}{c}\mathbf{N H}_{3}-\mathbf{N} \\
(\mathbf{m g N} / \mathbf{L})\end{array}$ & $\begin{array}{c}\mathbf{N K T} \\
(\mathbf{m g N} / \mathbf{L})\end{array}$ & $\begin{array}{c}\mathbf{N H}_{3}-\mathbf{N} \\
(\mathbf{m g N} / \mathbf{L})\end{array}$ & $\begin{array}{c}\mathbf{N K T} \\
(\mathbf{m g N} / \mathbf{L})\end{array}$ & $\begin{array}{c}\mathbf{N H}_{3}-\mathbf{N} \\
(\mathbf{m g N} / \mathbf{L})\end{array}$ \\
\hline Núm. dados & 22 & 24 & 22 & 24 & 22 & 24 \\
Mediana & 71 & 59 & 54 & 48 & 8 & 3 \\
Média & 73 & 59 & 51 & 42 & 10 & 5 \\
Mínimo & 11 & 32 & 11 & 4 & 0 & 0 \\
Máximo & 106 & 78 & 92 & 66 & 32 & 27 \\
Coef. Var. & 0,25 & 0,15 & 0,40 & 0,41 & 0,91 & 1,34 \\
Desvio padrão & 18,6 & 8,8 & 20,6 & 16,9 & 9,5 & 6,8 \\
\hline
\end{tabular}

Tabela 19 - Resultados de NKT e $\mathrm{NH}_{3}-\mathrm{N}$ no afluente e efluentes finais - Fase 2

\begin{tabular}{ccccccc}
\hline & \multicolumn{2}{c}{ Afluente } & \multicolumn{2}{c}{ Efluente Lodo Ativado } & \multicolumn{2}{c}{ Efluente MBBR } \\
& $\begin{array}{c}\mathbf{N K T} \\
(\mathbf{m g N} / \mathbf{L})\end{array}$ & $\begin{array}{c}\mathbf{N H}_{3}-\mathbf{N} \\
(\mathbf{m g N} / \mathbf{L})\end{array}$ & $\begin{array}{c}\mathbf{N K T} \\
(\mathbf{m g N} / \mathbf{L})\end{array}$ & $\begin{array}{c}\mathbf{N H}_{\mathbf{3}}-\mathbf{N} \\
(\mathbf{m g N} / \mathbf{L})\end{array}$ & $\begin{array}{c}\mathbf{N K T} \\
(\mathbf{m g N} / \mathbf{L})\end{array}$ & $\begin{array}{c}\mathbf{N H}_{3}-\mathbf{N} \\
(\mathbf{m g N} / \mathbf{L})\end{array}$ \\
\hline Núm. dados & 17 & 17 & 17 & 17 & 17 & 17 \\
Mediana & 88 & 67 & 7 & 1 & 4 & 1 \\
Média & 97 & 65 & 13 & 6 & 6 & 1 \\
Mínimo & 66 & 48 & 0 & 0 & 0 & 0 \\
Máximo & 189 & 83 & 45 & 34 & 28 & 8 \\
Coef. Var. & 0,30 & 0,14 & 1,04 & 1,48 & 1,18 & 1,65 \\
Desvio padrão & 29,2 & 8,8 & 14,0 & 9,2 & 7,2 & 2,0 \\
\hline
\end{tabular}

Tabela 20- Resultados de NKT e $\mathrm{NH}_{3}-\mathrm{N}$ no afluente e efluentes finais - Fase 3

\begin{tabular}{ccccccc}
\hline & \multicolumn{2}{c}{ Afluente } & \multicolumn{2}{c}{ Efluente Lodo Ativado } & \multicolumn{2}{c}{ Efluente MBBR } \\
& $\begin{array}{c}\mathbf{N K T} \\
(\mathbf{m g N} / \mathbf{L})\end{array}$ & $\begin{array}{c}\mathbf{N H}_{3}-\mathbf{N} \\
(\mathbf{m g N} \mathbf{L})\end{array}$ & $\begin{array}{c}\mathbf{N K T} \\
(\mathbf{m g N} / \mathbf{L})\end{array}$ & $\begin{array}{c}\mathbf{N H}_{3}-\mathbf{N} \\
(\mathbf{m g N} / \mathbf{L})\end{array}$ & $\begin{array}{c}\mathbf{N K T} \\
(\mathbf{m g N} \mathbf{L})\end{array}$ & $\begin{array}{c}\mathbf{N H}_{3}-\mathbf{N} \\
(\mathbf{m g N} \mathbf{L})\end{array}$ \\
\hline Núm. dados & 3 & 3 & 3 & 3 & 3 & 3 \\
Mediana & 63 & 56 & 35 & 21 & 4 & 2 \\
Média & 75 & 57 & 37 & 23 & 4 & 2 \\
Mínimo & 63 & 46 & 29 & 20 & 4 & 2 \\
Máximo & 98 & 68 & 48 & 29 & 4 & 2 \\
Coef. Var. & 0,27 & 0,19 & 0,27 & 0,22 & 0,08 & 0,16 \\
Desvio padrão & 20,2 & 10,9 & 10,0 & 5,0 & 0,3 & 0,3 \\
\hline
\end{tabular}




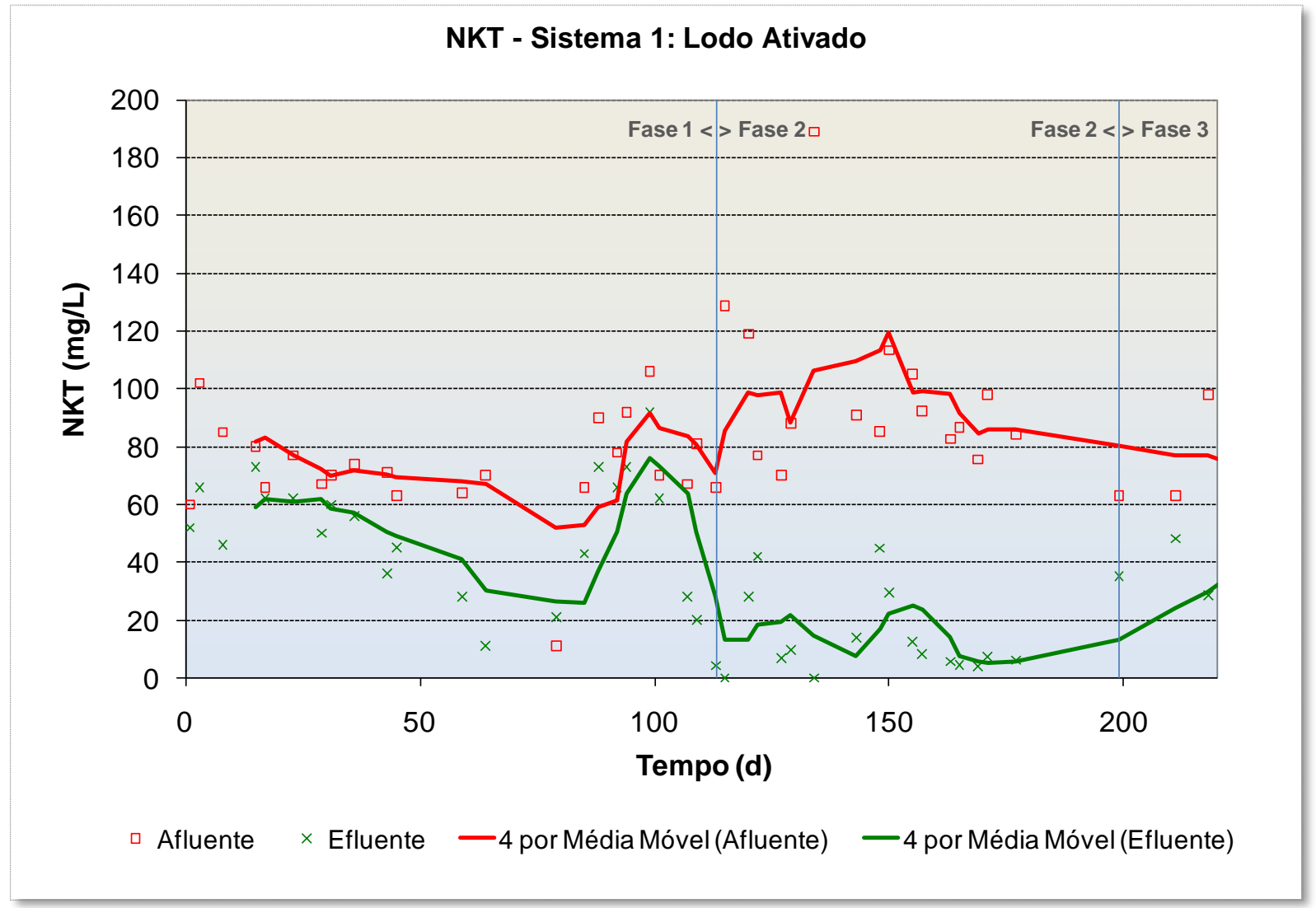

Figura 30 - Resultados de Nitrogênio Total Kjeldahl - Lodo ativado

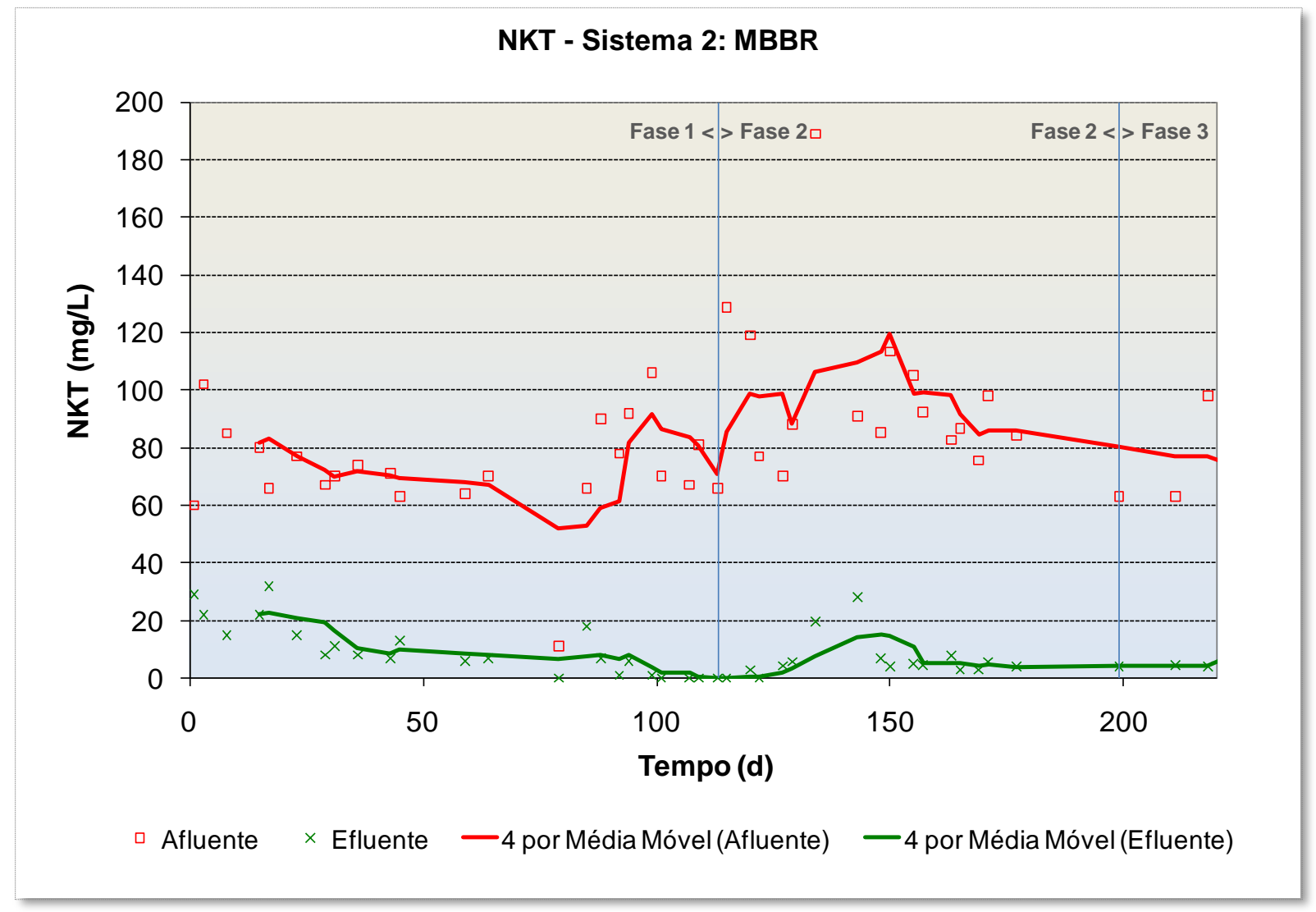

Figura 31 - Resultados de Nitrogênio Total Kjeldahl - MBBR 


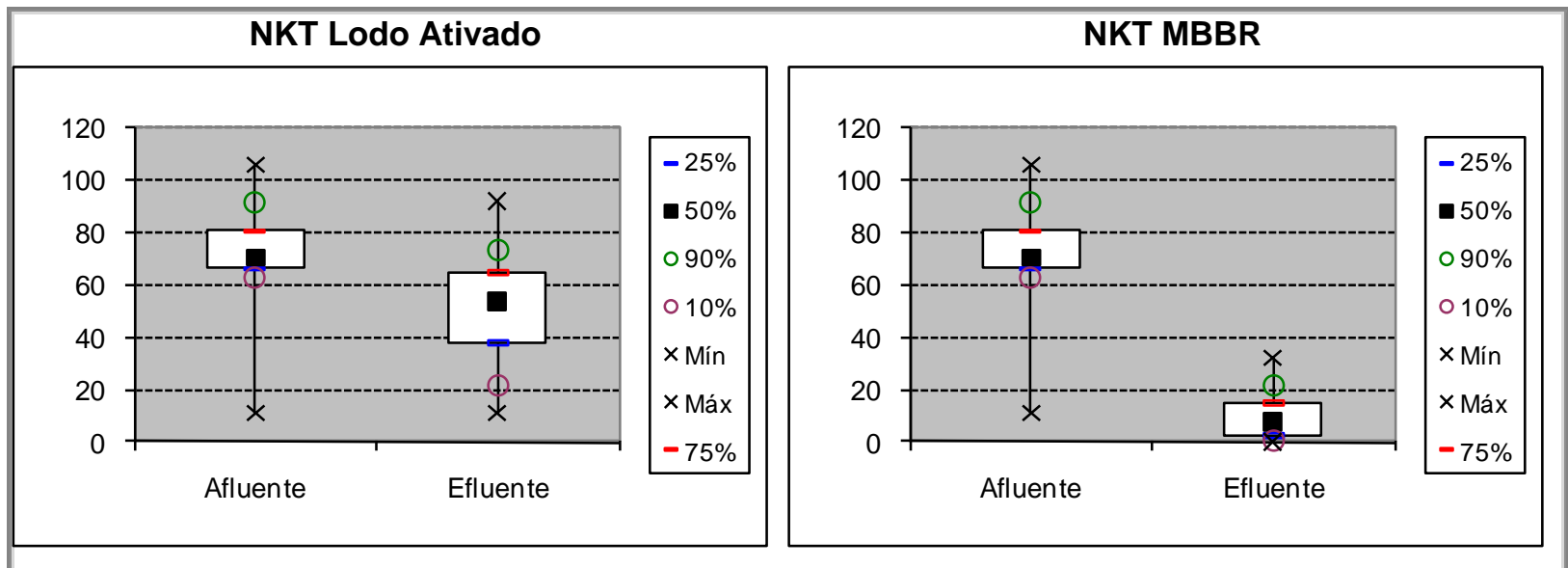

Figura 32 - Diagramas Box-Whiskers - Nitrogênio Total Kjeldahl - Fase 1

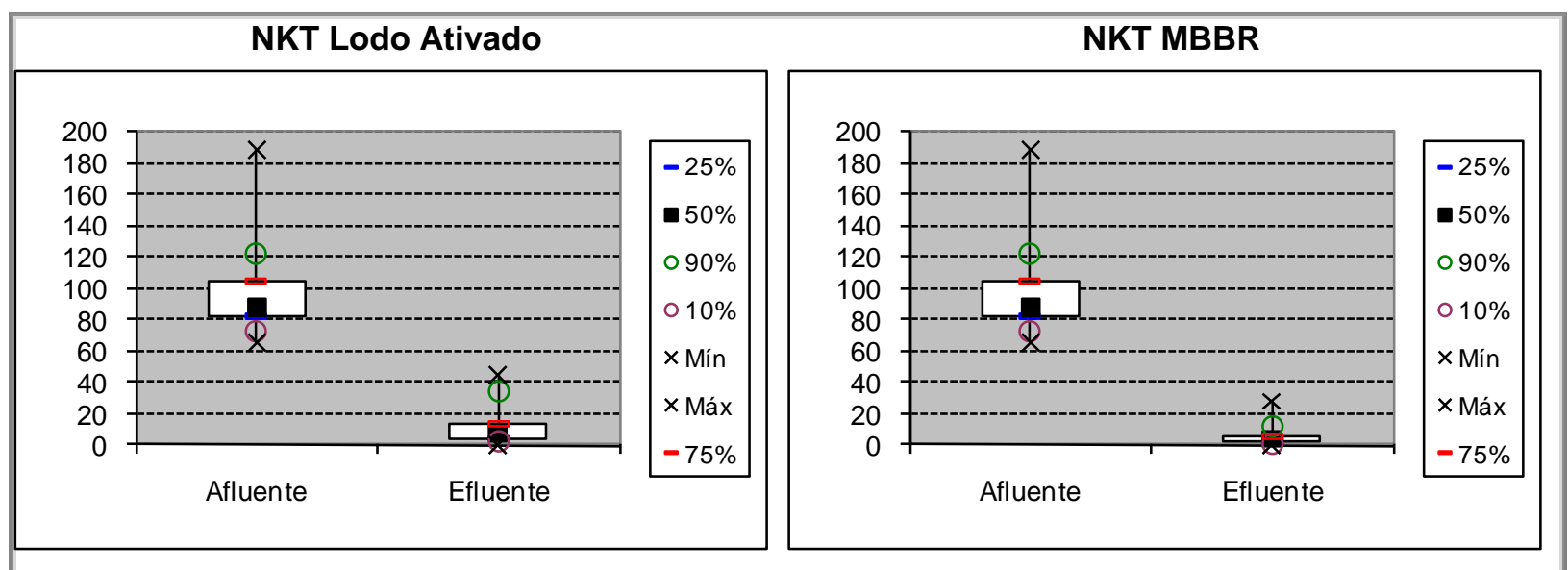

Figura 33 - Diagramas Box-Whiskers - Nitrogênio Total Kjeldahl - Fase 2

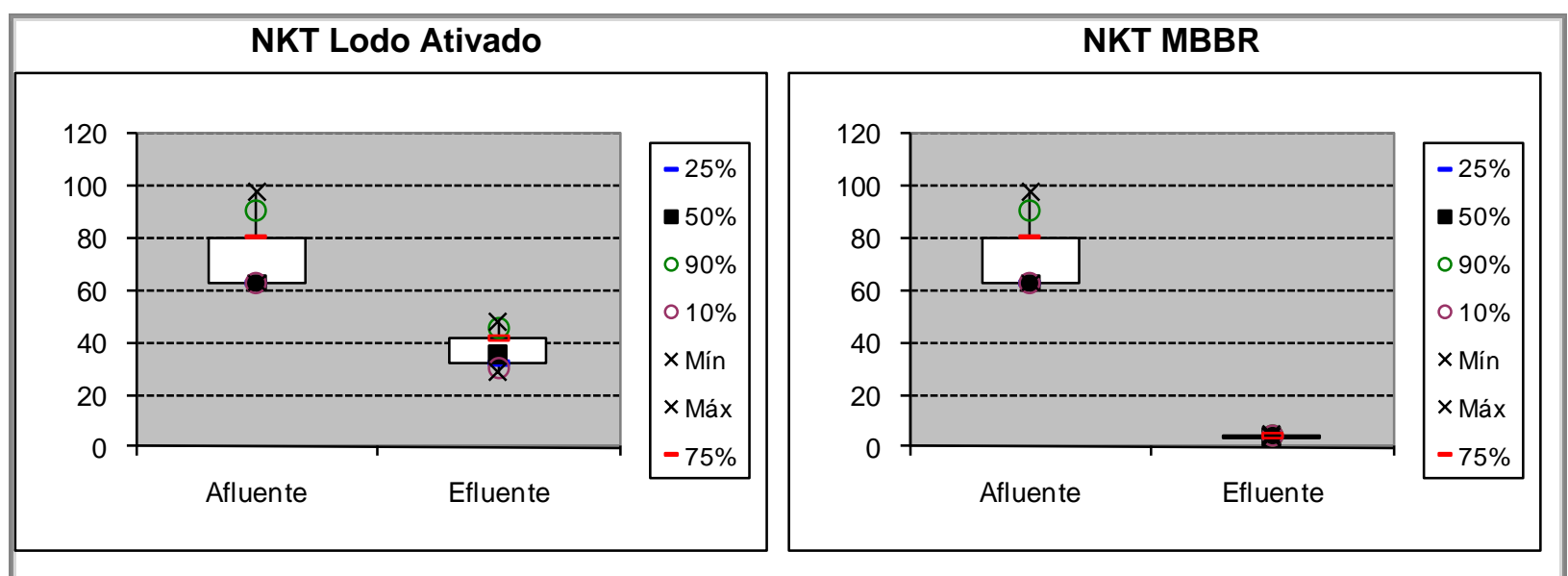

Figura 34 - Diagramas Box-Whiskers - Nitrogênio Total Kjeldahl - Fase 3 


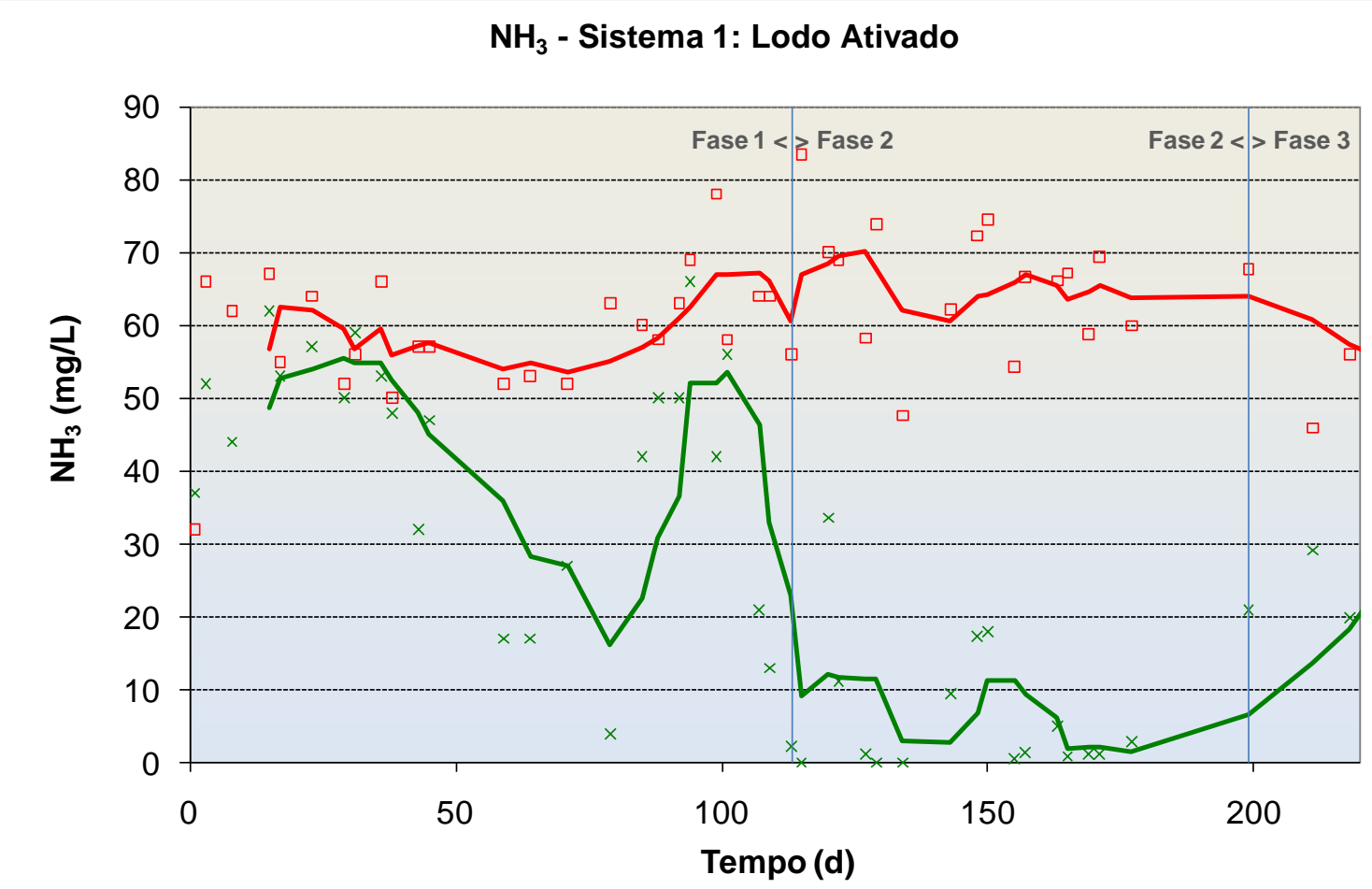

$\square$ Afluente $\times$ Efluente —4 por Média Móvel (Afluente) —4 por Média Móvel (Efluente)

Figura 35 - Resultados de Nitrogênio Amoniacal - Lodo ativado

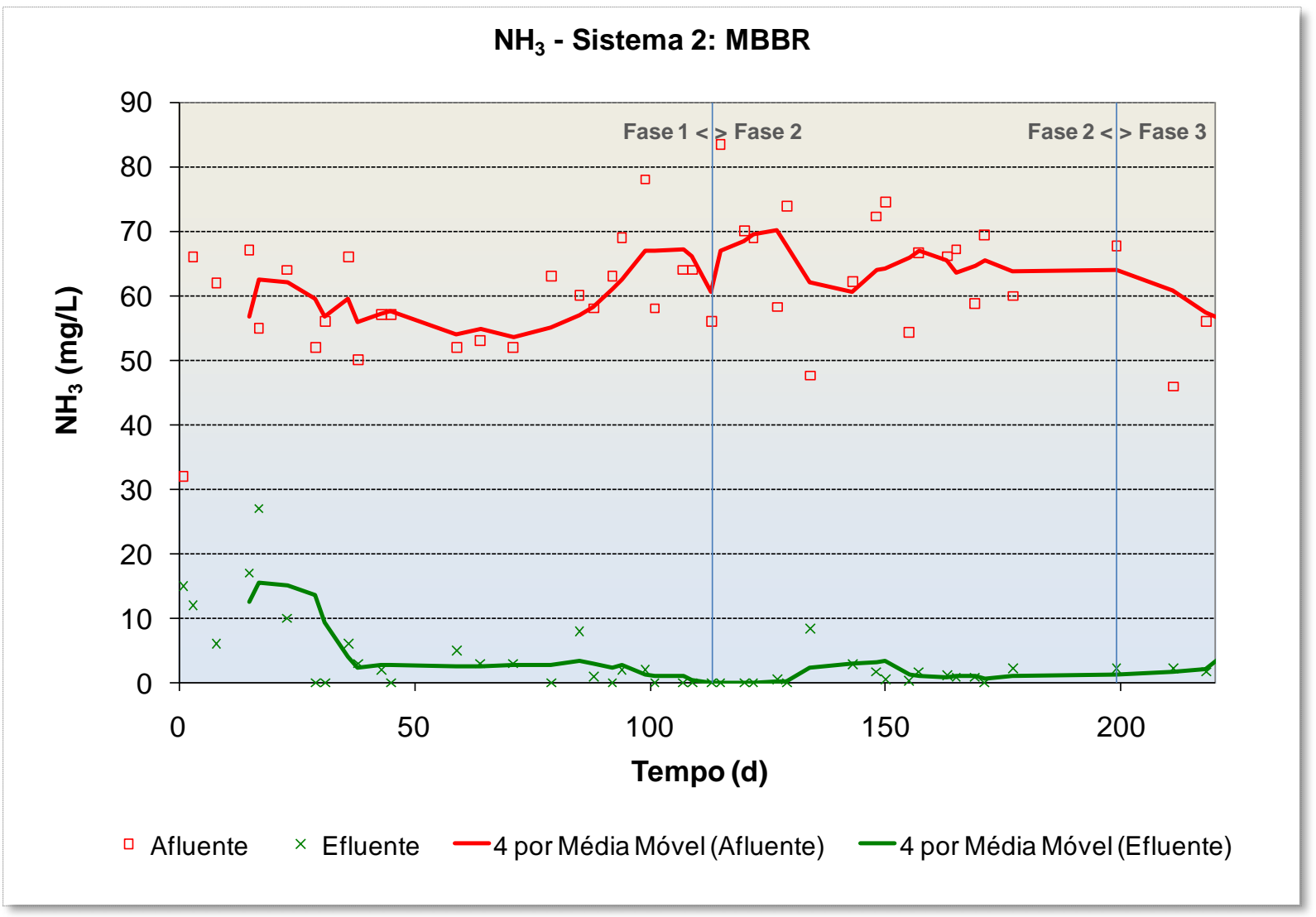

Figura 36 - Resultados de Nitrogênio Amoniacal - MBBR 


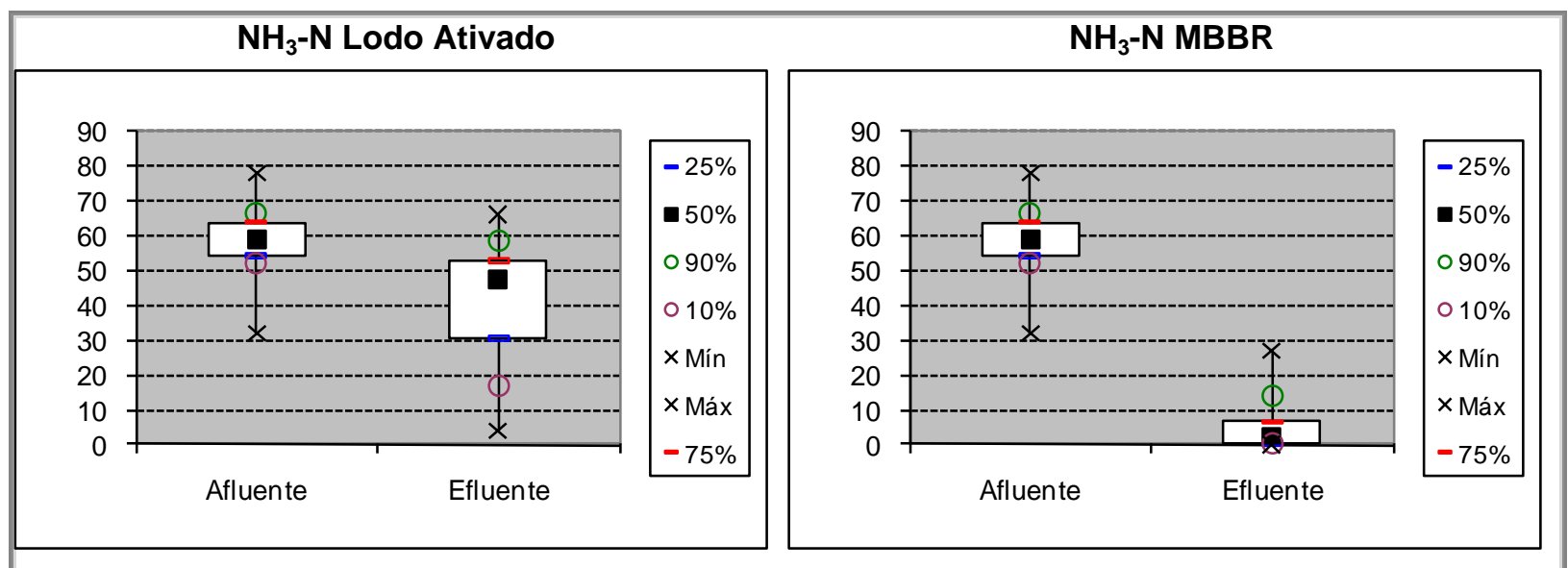

Figura 37 - Diagramas Box-Whiskers - Nitrogênio Amoniacal - Fase 1

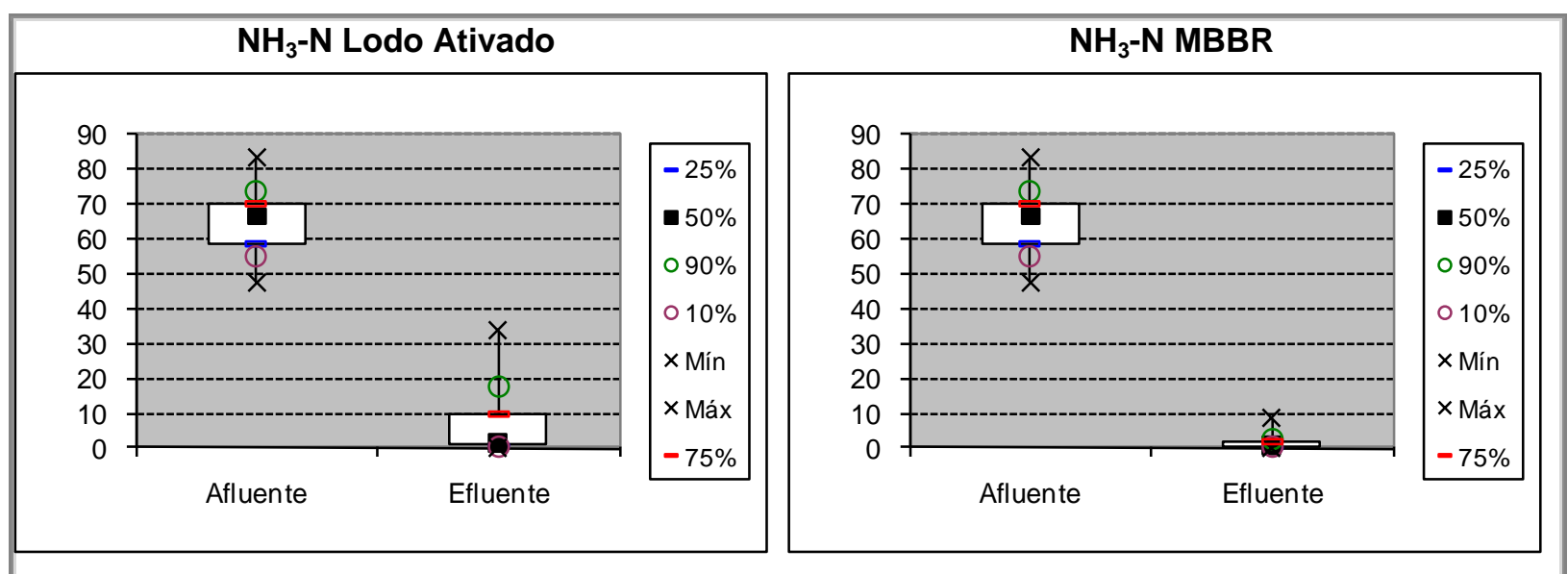

Figura 38 - Diagramas Box-Whiskers - Nitrogênio Amoniacal - Fase 2

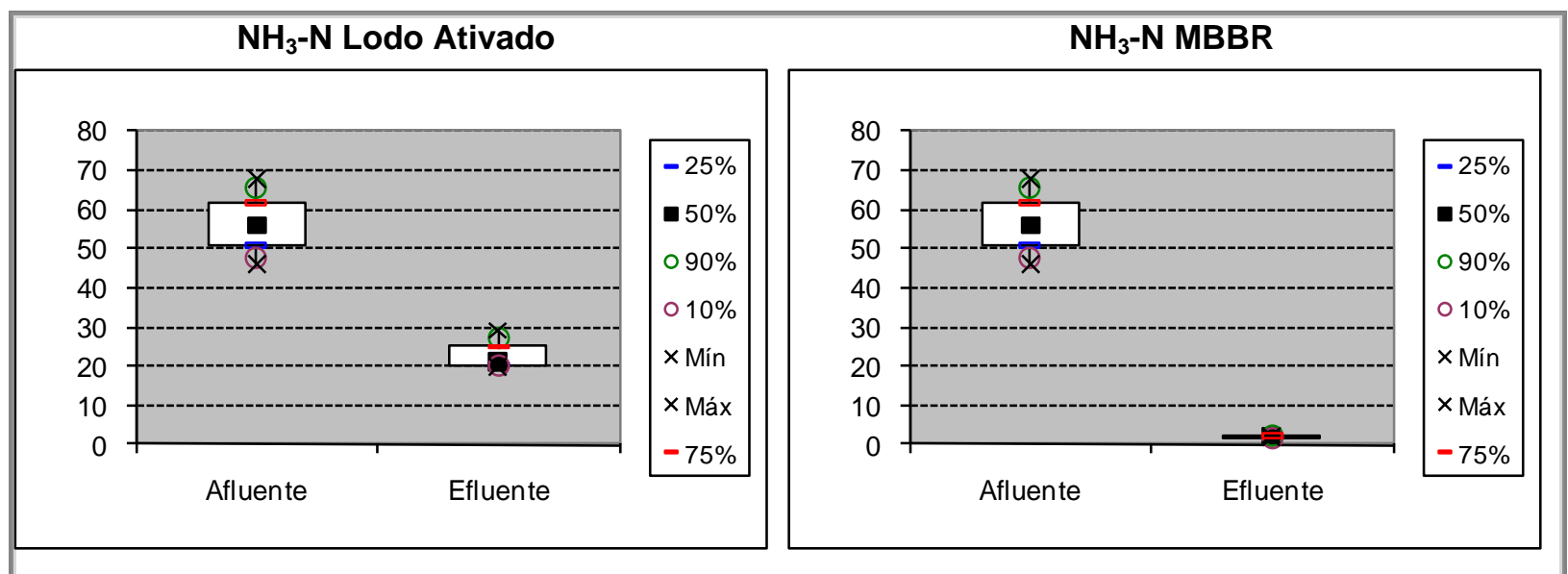

Figura 39 - Diagramas Box-Whiskers - Nitrogênio Amoniacal - Fase 3

Observa-se nas Tabela 18 a 20 que as concentrações de nitrogênio total e amoniacal do afluente são elevadas, provavelmente em função do esgoto gerado no refeitório central da USP. Observa-se também um nível baixo de nitrificação do lodo 
ativado na primeira fase, enquanto que no MBBR este processo ocorreu com eficiência elevada. Nas séries históricas de nitrogênio amoniacal, observa-se que exceto o período inicial de operação do sistema, no MBBR a nitrificação ocorreu de forma praticamente completa. No processo de lodo ativado, o nível de nitrificação aumentou em torno do $90^{\circ}$ dia de operação, em função da elevação da temperatura após o mês frio de Agosto de 2010.

A principal hipótese formulada para a justificativa foi a de que a idade do lodo aeróbia, resultou em valores da ordem de 6 dias apenas e as baixas temperaturas registradas no período, atingindo a apenas $14^{\circ} \mathrm{C}$ nos lodos dos reatores, contribuiram para o insucesso da nitrificação no lodo ativado, enquanto que no MBBR, a presença da biomassa aderida garantiu a permanência das bactérias nitrificantes no sistema.

Nas Tabelas 21, 22 e 23 são apresentados os resultados de nitrito e nitrato. Os resultados de nitrito e nitrato são lançados em gráfico nas Figuras de 40 a 47.

Tabela 21 - Resultados de concentrações de nitrito nos efluentes dos processos de lodo ativado e MBBR - Fase 1

\begin{tabular}{|c|c|c|c|c|}
\hline & \multicolumn{2}{|c|}{ Efluente Lodo Ativado } & \multicolumn{2}{|c|}{ Efluente MBBR } \\
\hline & $\begin{array}{c}\mathrm{NO}_{2}^{-} \\
\left(\mathrm{mgN}^{-} \mathrm{L}\right)\end{array}$ & $\begin{array}{c}\mathrm{NO}_{3}^{-} \\
(\mathrm{mgN} / \mathrm{L})\end{array}$ & $\begin{array}{c}\mathrm{NO}_{2}^{-} \\
(\mathrm{mgN} / \mathrm{L})\end{array}$ & $\begin{array}{c}\mathrm{NO}_{3}^{-} \\
(\mathrm{mgN} / \mathrm{L})\end{array}$ \\
\hline Núm. dados & 20 & 11 & 20 & 11 \\
\hline Mediana & 0,06 & 0,19 & 1,23 & 4,75 \\
\hline Média & 0,61 & 1,72 & 1,60 & 4,45 \\
\hline Mínimo & 0,00 & 0,02 & 0,07 & 0,00 \\
\hline Máximo & 7,36 & 8,56 & 5,00 & 8,39 \\
\hline Coef. Var. & 2,69 & 1,82 & 0,90 & 0,63 \\
\hline Desvio padrão & 0,9 & 3,1 & 1,4 & 2,8 \\
\hline
\end{tabular}


Tabela 22 - Resultados de concentrações de nitrito nos efluentes dos processos de lodo ativado e MBBR - Fase 2

\begin{tabular}{|c|c|c|c|c|}
\hline & \multicolumn{2}{|c|}{ Efluente Lodo Ativado } & \multicolumn{2}{|c|}{ Efluente MBBR } \\
\hline & $\begin{array}{c}\mathrm{NO}_{2}^{-} \\
(\mathrm{mgN} / \mathrm{L})\end{array}$ & $\begin{array}{c}\mathrm{NO}_{3}^{-} \\
(\mathrm{mgN} / \mathrm{L})\end{array}$ & $\begin{array}{c}\mathrm{NO}_{2}^{-} \\
(\mathrm{mgN} / \mathrm{L})\end{array}$ & $\begin{array}{c}\mathrm{NO}_{3}^{-} \\
(\mathrm{mgN} / \mathrm{L})\end{array}$ \\
\hline Núm. dados & 16 & 15 & 16 & 16 \\
\hline Mediana & 0,09 & 0,09 & 0,71 & 2,95 \\
\hline Média & 0,37 & 0,22 & 1,21 & 4,29 \\
\hline Mínimo & 0,00 & 0,00 & 0,06 & 0,00 \\
\hline Máximo & 1,42 & 1,23 & 6,84 & 12,01 \\
\hline Coef. Var. & 1,43 & 1,50 & 1,35 & 0,87 \\
\hline Desvio padrão & 0,5 & 0,3 & 1,6 & 3,7 \\
\hline
\end{tabular}

Tabela 23 - Resultados de concentrações de nitrito nos efluentes dos processos de lodo ativado e MBBR - Fase 3

\begin{tabular}{|c|c|c|c|c|}
\hline & \multicolumn{2}{|c|}{ Efluente Lodo Ativado } & \multicolumn{2}{|c|}{ Efluente MBBR } \\
\hline & $\begin{array}{c}\mathrm{NO}_{2}^{-} \\
(\mathrm{mgN} / \mathrm{L})\end{array}$ & $\begin{array}{c}\mathrm{NO}_{3}^{-} \\
(\mathrm{mgN} / \mathrm{L})\end{array}$ & $\begin{array}{c}\mathrm{NO}_{2}^{-} \\
(\mathrm{mgN} / \mathrm{L})\end{array}$ & $\begin{array}{c}\mathrm{NO}_{3}^{-} \\
(\mathrm{mgN} / \mathrm{L})\end{array}$ \\
\hline Núm. dados & 2 & 3 & 2 & 4 \\
\hline Mediana & 0,16 & 0,17 & 0,50 & 14,25 \\
\hline Média & 0,16 & 0,18 & 0,50 & 12,94 \\
\hline Mínimo & 0,07 & 0,15 & 0,26 & 6,47 \\
\hline Máximo & 0,25 & 0,21 & 0,73 & 16,80 \\
\hline Coef. Var. & 0,76 & 0,17 & 0,68 & 0,35 \\
\hline Desvio padrão & 0,1 & 0,0 & 0,3 & 4,6 \\
\hline
\end{tabular}




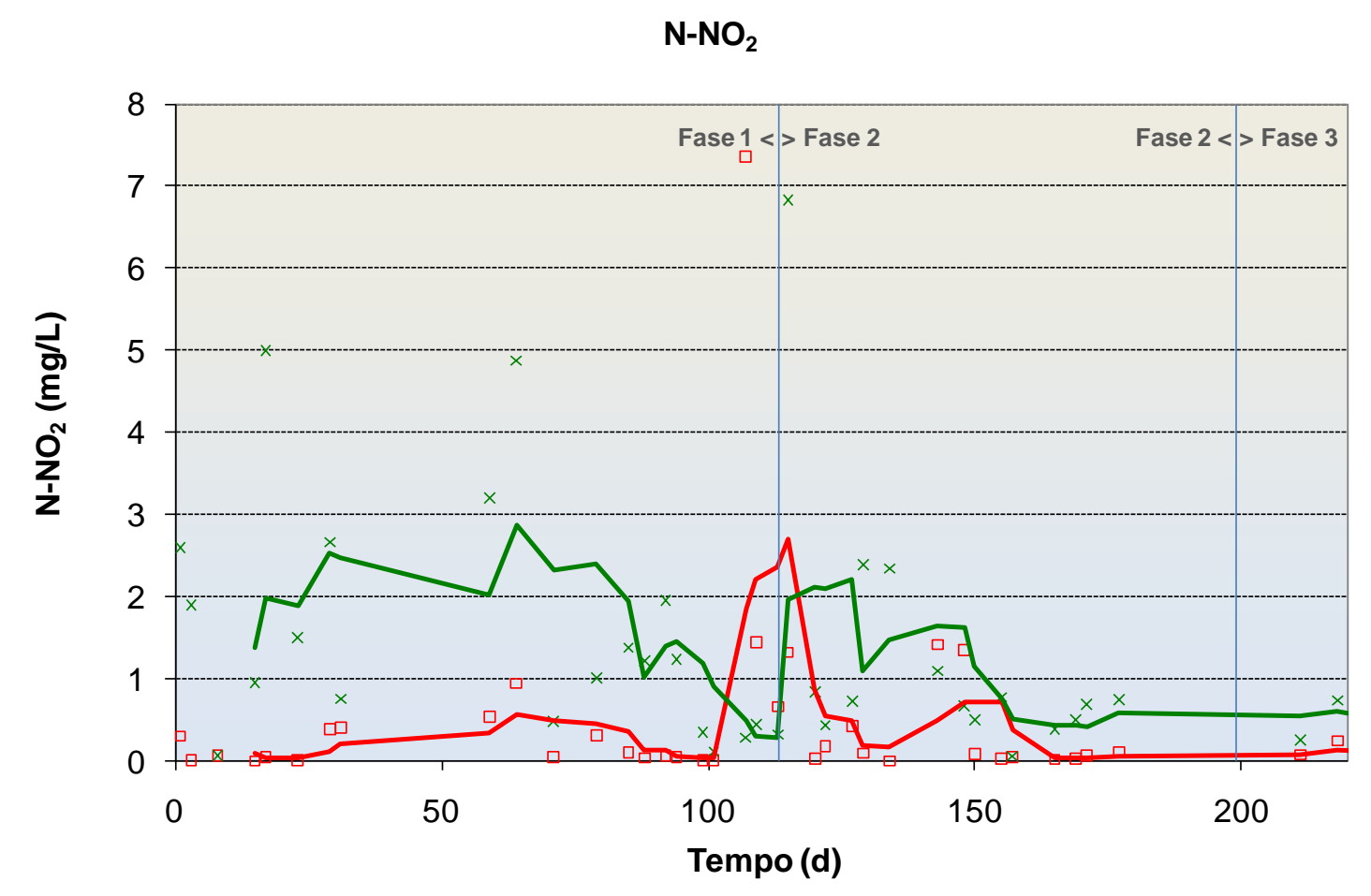

- NNO2 LA $\times$ NNO2 MBBR — 4 por Média Móvel (NNO2 LA) — 4 por Média Móvel (NNO2 MBBR)

Figura 40 - Série histórica de Nitrito nos efluentes

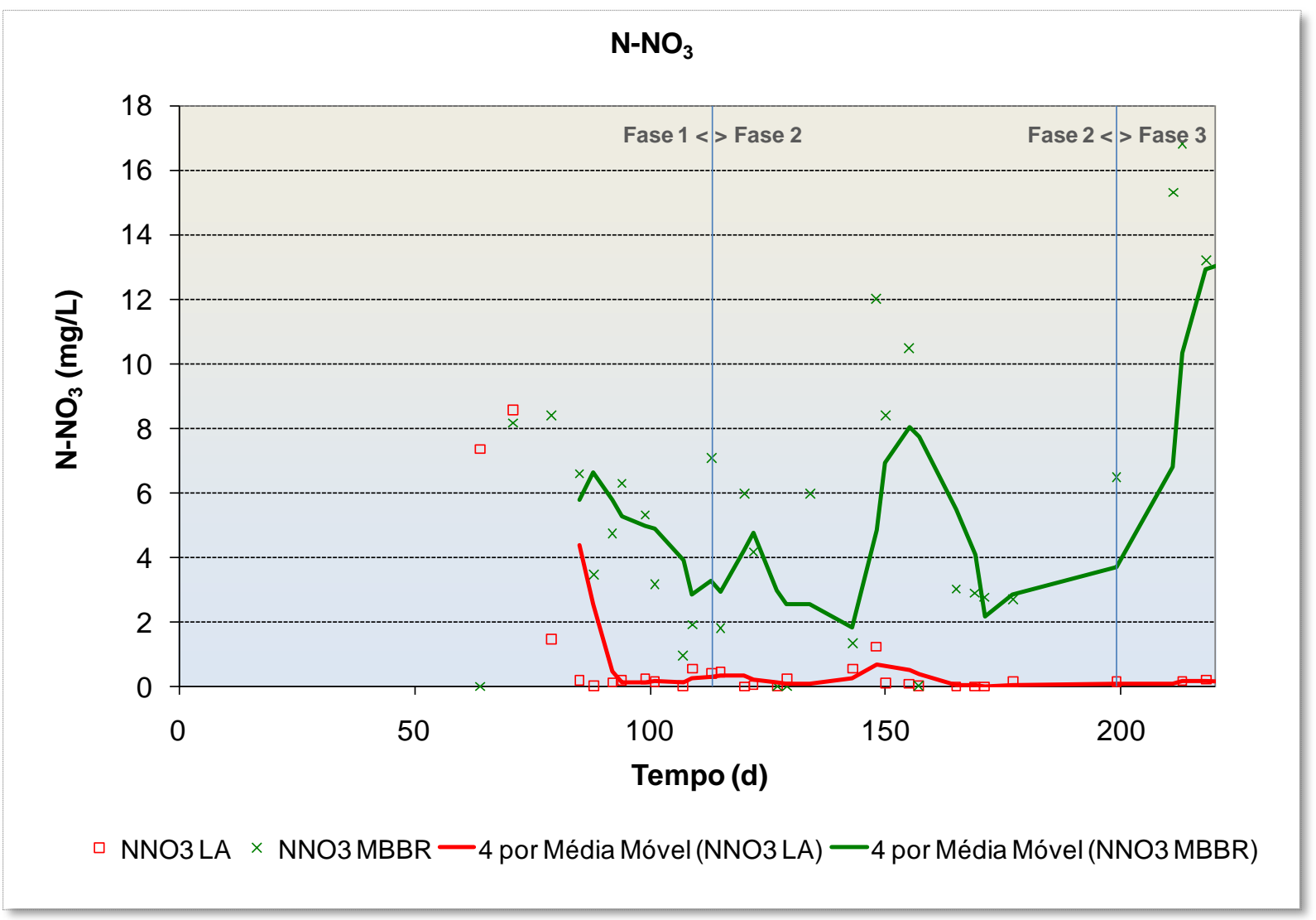

Figura 41 - Série histórica de Nitrato nos efluentes 


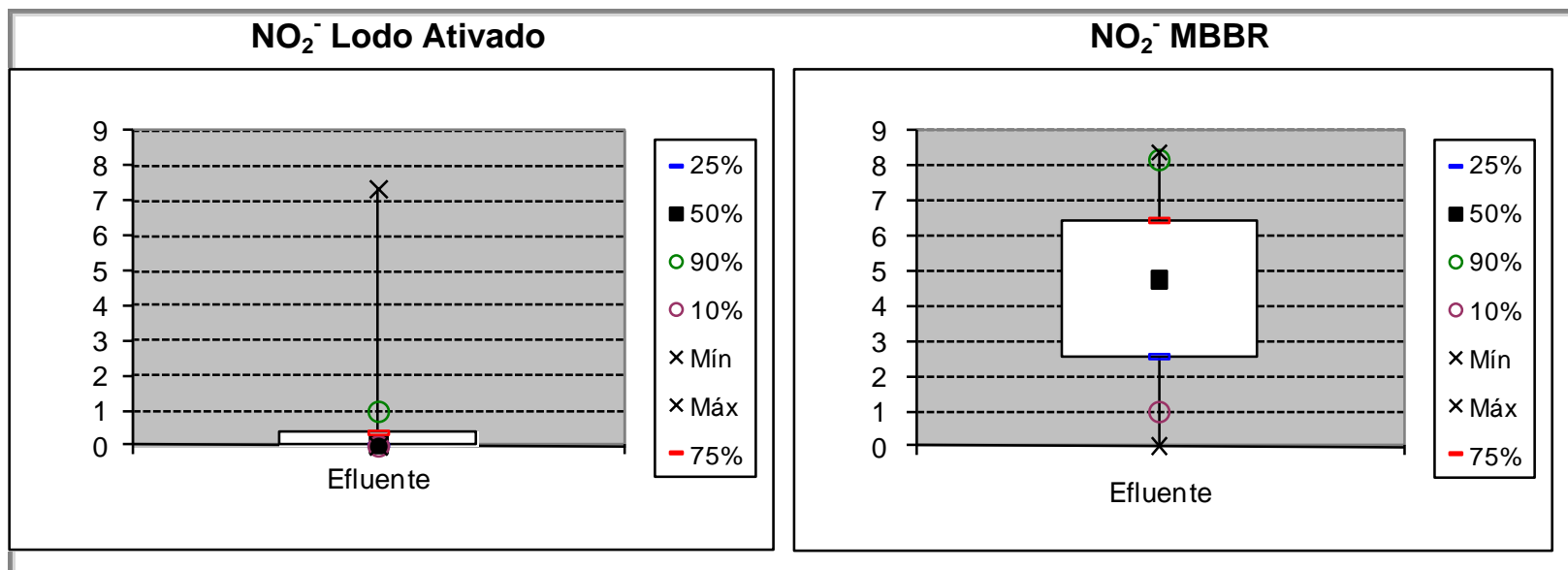

Figura 42 - Diagramas Box-Whiskers de concentração de nitrito nos efluentes - Fase 1

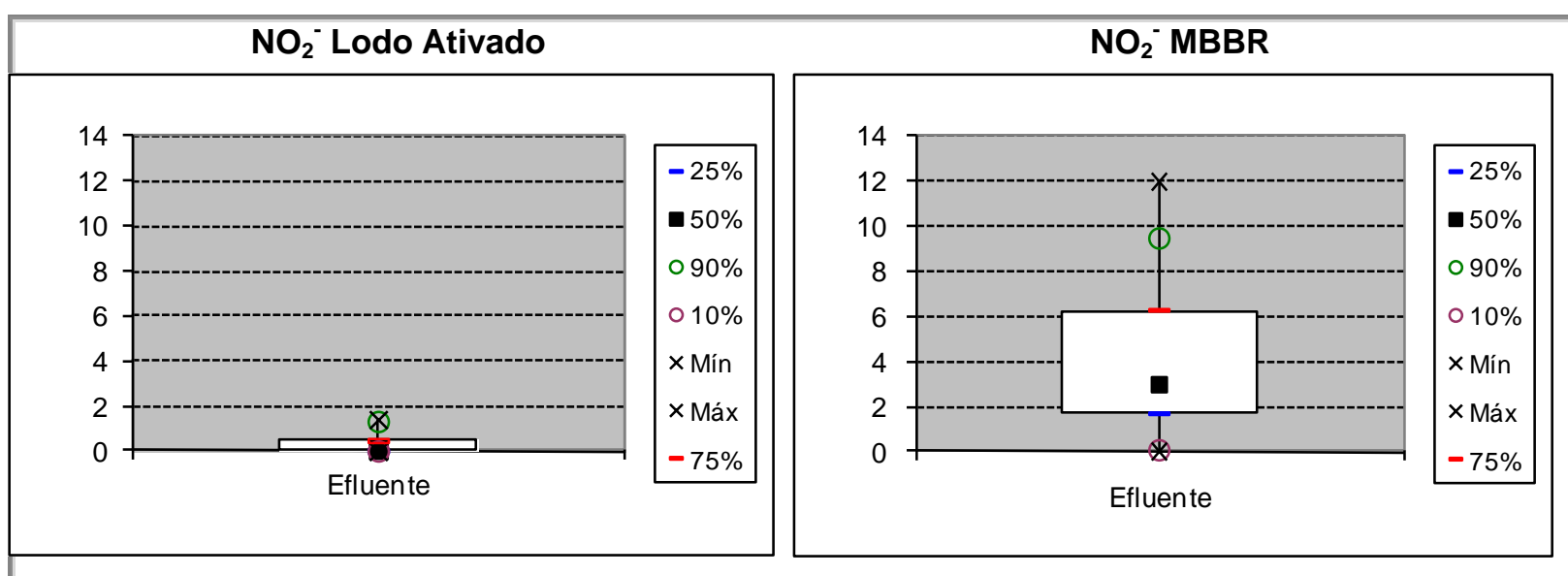

Figura 43 - Diagramas Box-Whiskers de concentração de nitrito nos efluentes - Fase 2

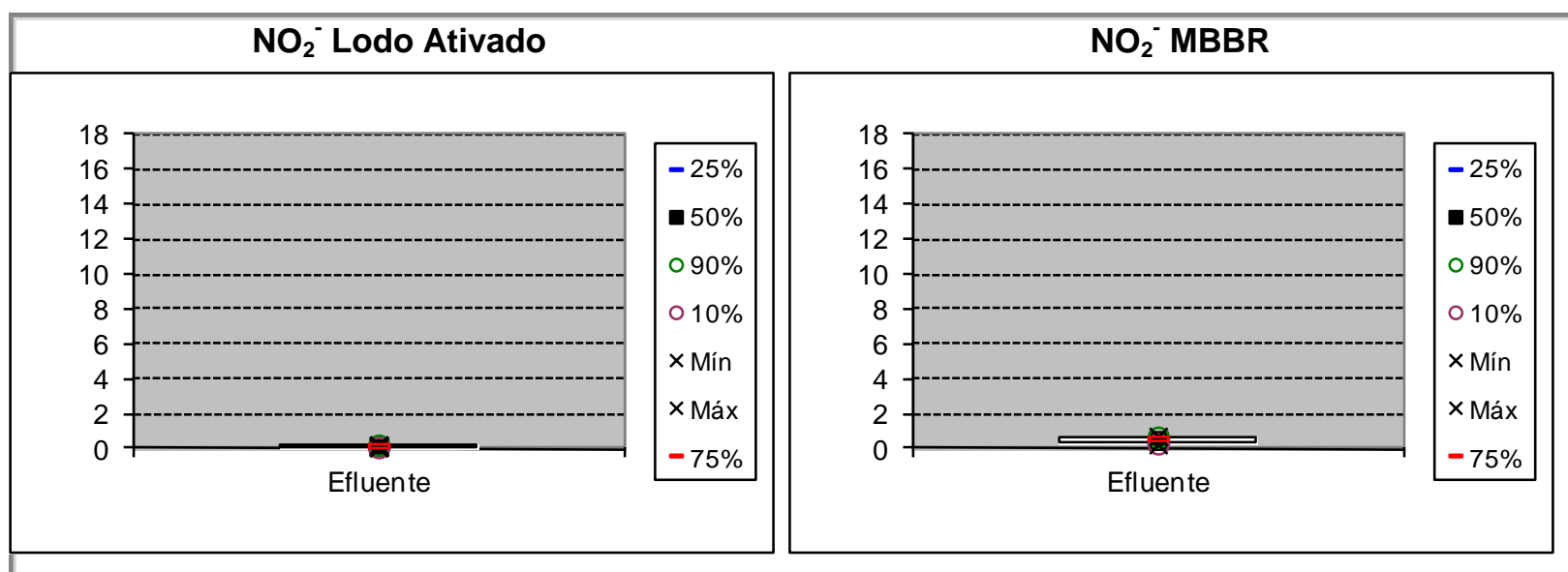

Figura 44 - Diagramas Box-Whiskers de concentração de nitrito nos efluentes - Fase 3 


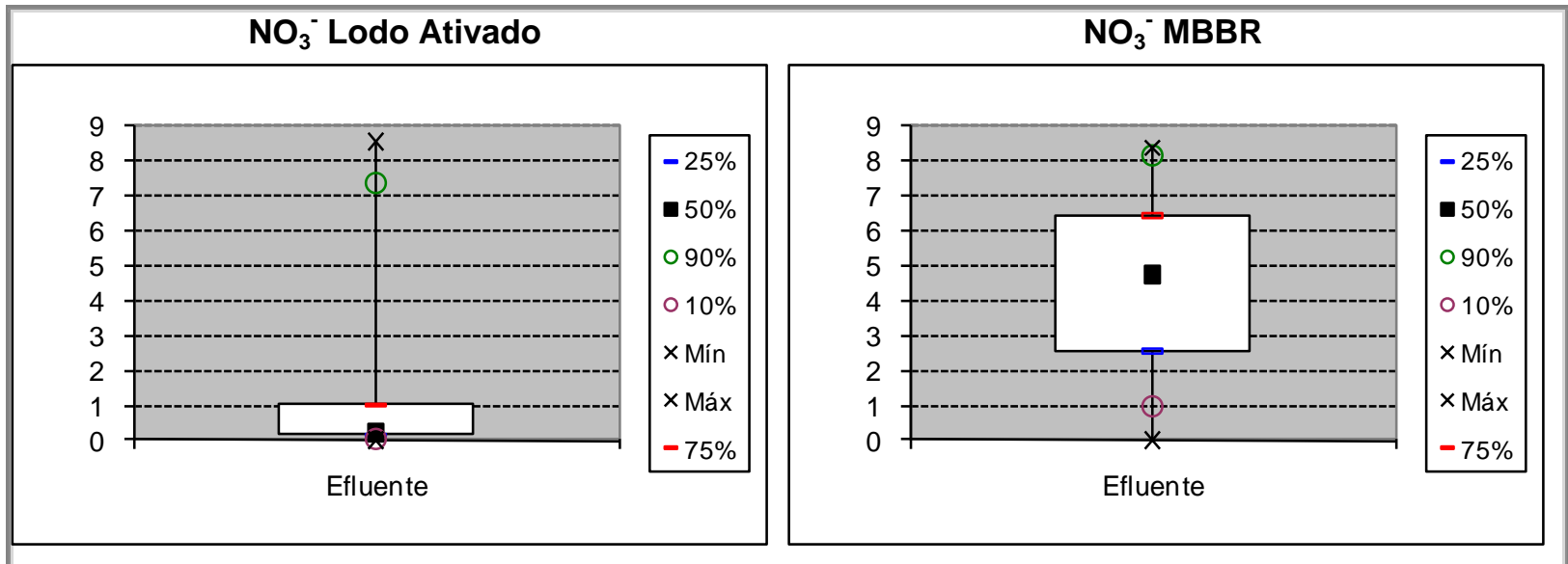

Figura 45 - Diagramas Box-Whiskers de concentração de nitrato nos efluentes - Fase 1

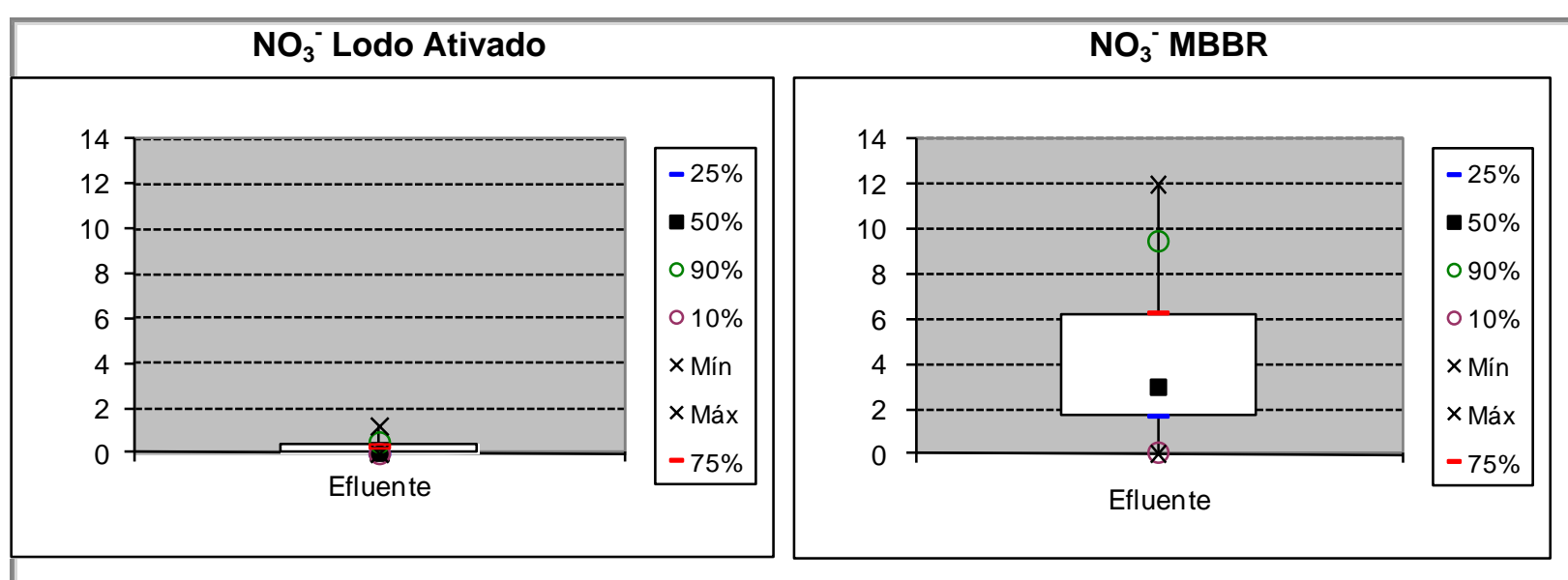

Figura 46 - Diagramas Box-Whiskers de concentração de nitrato nos efluentes - Fase 2

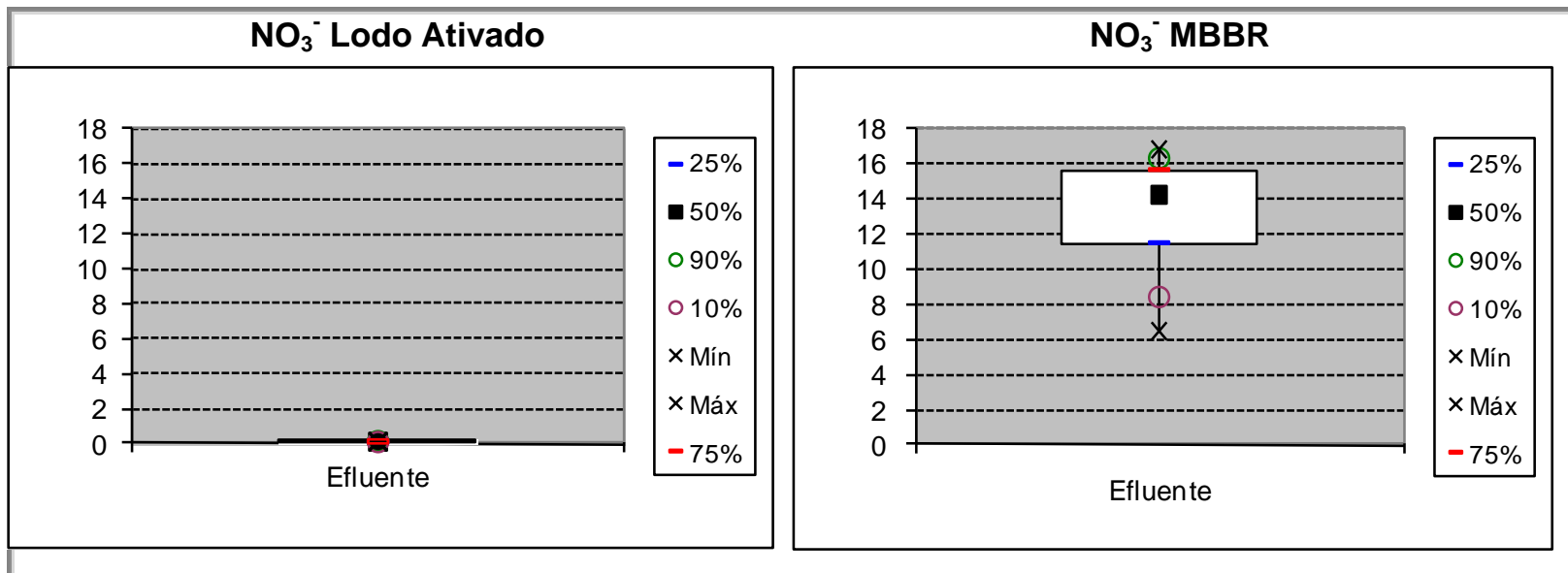

Figura 47 - Diagramas Box-Whiskers de concentração de nitrato nos efluentes - Fase 3

Observa-se na Tabela 20 que ambos os efluentes apresentaram baixas concentrações de nitrito e nitrato na primeira fase, por motivos diferentes. No caso do lodo ativado, por que praticamente não ocorreu nitrificação, exceto de forma 
parcial em torno do $70^{\circ}$ dia (Figura 40). No caso do MBBR, ocorreu nitrificação e desnitrificação, sendo que ocorreram alguns períodos de concentração mais elevadas de nitrito (Figura 40) e nitrato (Figura 41) no efluente, devido à ocorrência de falhas no sistema de reciclo interno de lodo. Nas fases 2 e 3, enquanto ocorreu nitrificação no lodo ativado todo o nitrato foi consumido na desnitrificação e o nitrogênio foi satisfatoriamente removido. No mesmo período no MBBR a deficiência no reciclo interno permaneceu acontecendo e problemas na agitação da câmara anóxica impossibilitaram a efetivação adequada da desnitrificação, evidenciada pelo aumento das concentrações de nitrato registradas no efluente.

Nas Tabelas 24, 25 e 26 são apresentados os resultados de alcalinidade total no afluente e nos efluentes dos dois processos. Esses resultados são lançados em gráfico (Diagramas Box-Whiskers) nas Figuras 48, 49 e 50.

Tabela 24 - Resultados de alcalinidade total no afluente e efluentes dos reatores - Fase 1

\begin{tabular}{cccc}
\hline & \multicolumn{3}{c}{ Alcalinidade Total $\left(\mathrm{mg} \mathrm{CaCO}_{3} / \mathbf{L}\right)$} \\
Afluente & $\begin{array}{c}\text { Efl. Lodo } \\
\text { Ativado }\end{array}$ & $\begin{array}{c}\text { Efluente } \\
\text { MBBR }\end{array}$ \\
\hline Núm. dados & 6 & 6 & 6 \\
Mediana & 221 & 208 & 31 \\
Média & 221 & 189 & 32 \\
Mínimo & 170 & 102 & 20 \\
Máximo & 282 & 260 & 45 \\
Coef. Var. & 0,17 & 0,38 & 0,29 \\
Desvio padrão & 37,4 & 72,2 & 9,3 \\
\hline
\end{tabular}

Tabela 25 - Resultados de alcalinidade total no afluente e efluentes dos reatores - Fase 2

Alcalinidade Total $\left(\mathrm{mg} \mathrm{CaCO}_{3} / \mathrm{L}\right)$

\begin{tabular}{cccc} 
& Afluente & $\begin{array}{c}\text { Efl. Lodo } \\
\text { Ativado }\end{array}$ & $\begin{array}{c}\text { Efluente } \\
\text { MBBR }\end{array}$ \\
\hline Núm. dados & 17 & 16 & 17 \\
Mediana & 210 & 76 & 25 \\
Média & 214 & 90 & 28 \\
Mínimo & 178 & 60 & 11 \\
Máximo & 264 & 162 & 57 \\
Coef. Var. & 0,12 & 0,35 & 0,43 \\
Desvio padrão & 25,5 & 31,4 & 12,2 \\
\hline
\end{tabular}


Tabela 26 - Resultados de alcalinidade total no afluente e efluentes dos reatores - Fase 3

\begin{tabular}{cccc} 
& \multicolumn{3}{c}{ Alcalinidade Total $\left(\mathrm{mg} \mathrm{CaCO}_{3} / \mathrm{L}\right)$} \\
& Afluente & $\begin{array}{c}\text { Efl. Lodo } \\
\text { Ativado }\end{array}$ & $\begin{array}{c}\text { Efluente } \\
\text { MBBR }\end{array}$ \\
\hline Núm. dados & 3 & 3 & 3 \\
Mediana & 180 & 160 & 40 \\
Média & 177 & 157 & 39 \\
Mínimo & 150 & 140 & 32 \\
Máximo & 200 & 170 & 45 \\
Coef. Var. & 0,14 & 0,10 & 0,17 \\
Desvio padrão & 25,2 & 15,3 & 6,6 \\
\hline
\end{tabular}

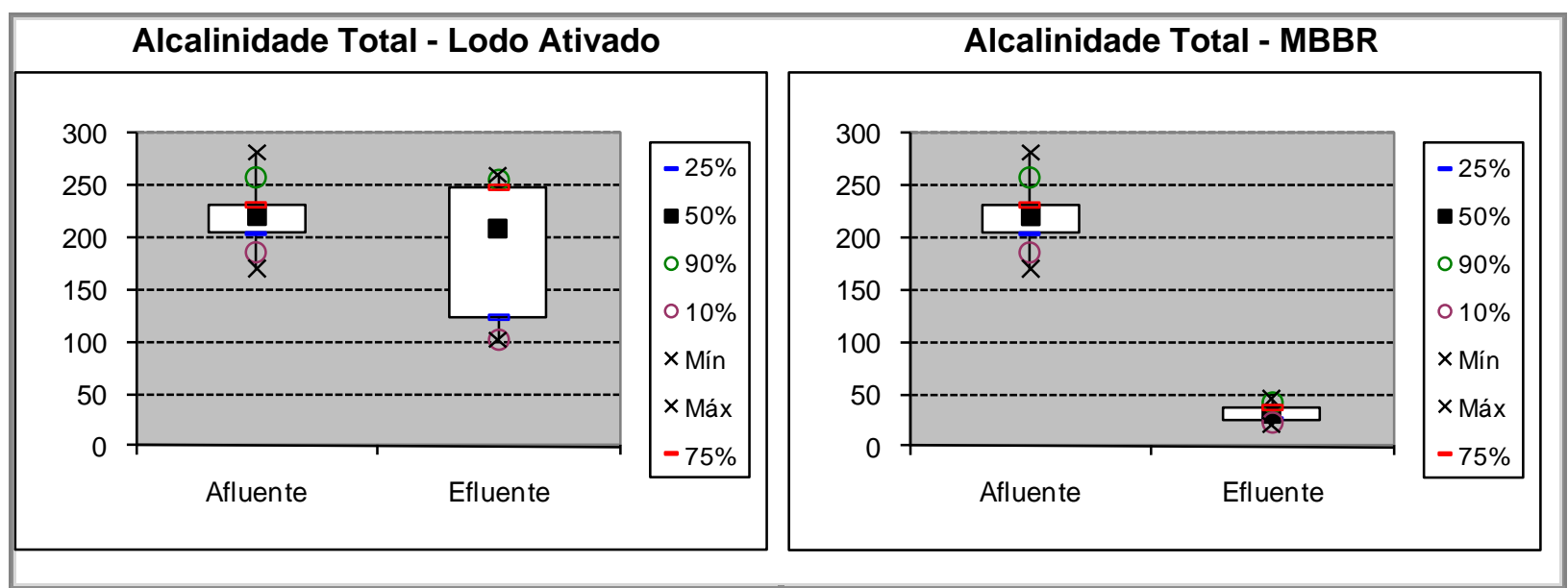

Figura 48 - Resultados de alcalinidade total no afluente e efluentes dos reatores - Fase 1

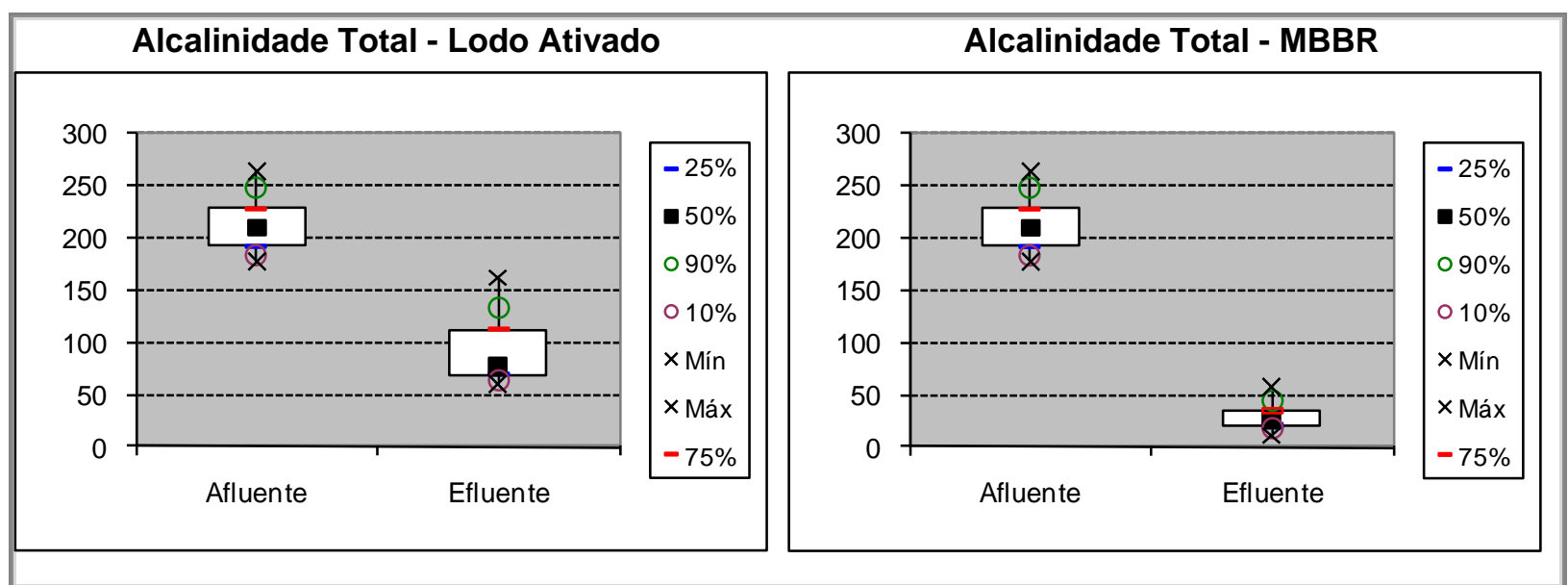

Figura 49 - Resultados de alcalinidade total no afluente e efluentes dos reatores - Fase 2 


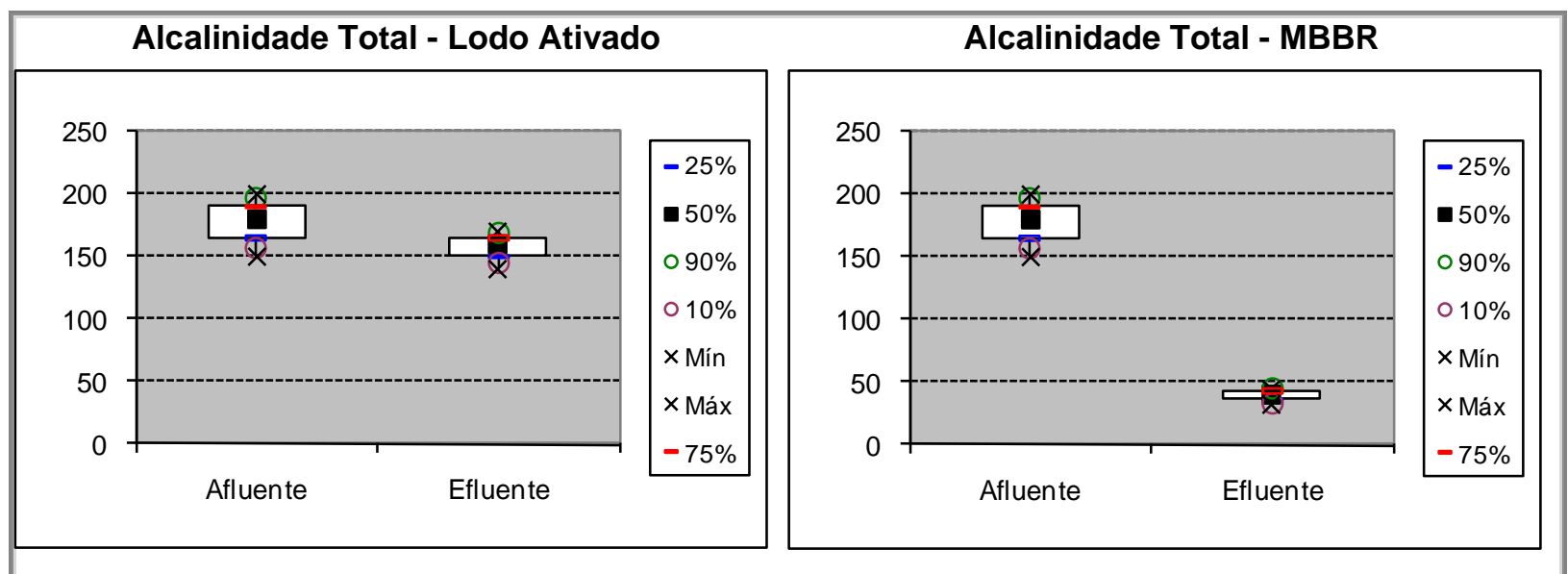

Figura 50 - Resultados de alcalinidade total no afluente e efluentes dos reatores - Fase 3

No MBBR, o consumo médio de alcalinidade durante as duas primeiras fases foi de aproximadamente $190 \mathrm{mg} \mathrm{CaCO} / \mathrm{L}$, como consequência da ocorrência de nitrificação. Os valores médios de alcalinidade efluente do sistema foram de 32, 28 e $39 \mathrm{mg} \mathrm{CaCO}_{3} / \mathrm{L}$, baixos em relação aos $50 \mathrm{mg} \mathrm{CaCO} / \mathrm{L}$ indicados com mínimo para sistemas MBBR. Em relação a essa condição ambiental o desempenho do sistema esteve potencialmente limitado.

\subsubsection{Caracterização da Biomassa nos Reatores}

\subsubsection{Caracterização Quantitativa da biomassa em suspensão}

Nas Tabelas 27, 28 e 29 são apresentados os resultados de SSV e SST nos lodos dos tanques de aeração. As séries históricas são apresentadas na Figura 51. Os dados são relativos apenas à biomassa em suspensão nos reatores. 
Tabela 27 - Resultados de SSV e SST nos lodos dos tanques de aeração - Fase 1

\begin{tabular}{ccccc}
\hline & \multicolumn{2}{c}{ Lodo Ativado } & \multicolumn{2}{c}{ MBBR } \\
& $\begin{array}{c}\text { SST } \\
(\mathbf{m g} / \mathbf{L})\end{array}$ & $\begin{array}{c}\text { SSV } \\
(\mathbf{m g} / \mathbf{L})\end{array}$ & $\begin{array}{c}\text { SST } \\
(\mathbf{m g} / \mathbf{L})\end{array}$ & $\begin{array}{c}\text { SSV } \\
(\mathbf{m g} / \mathbf{L})\end{array}$ \\
\hline Núm. dados & 26 & 26 & 26 & 26 \\
Mediana & 4215 & 3575 & 3774 & 3122 \\
Média & 4371 & 3734 & 3996 & 3417 \\
Mínimo & 1953 & 1713 & 1990 & 1487 \\
Máximo & 8500 & 6840 & 6120 & 5350 \\
Coef. Var. & 0,35 & 0,33 & 0,27 & 0,30 \\
Desvio padrão & 1515,0 & 1249,0 & 1097,0 & 1011,0 \\
\hline
\end{tabular}

Tabela 28 - Resultados de SSV e SST nos lodos dos tanques de aeração - Fase 2

Lodo Ativado

\begin{tabular}{ccccc} 
& $\begin{array}{c}\text { SST } \\
(\mathbf{m g} / \mathbf{L})\end{array}$ & $\begin{array}{c}\text { SSV } \\
(\mathbf{m g} / \mathbf{L})\end{array}$ & $\begin{array}{c}\text { SST } \\
(\mathbf{m g} / \mathbf{L})\end{array}$ & $\begin{array}{c}\text { SSV } \\
(\mathbf{m g} / \mathbf{L})\end{array}$ \\
\hline Núm. dados & 17 & 17 & 18 & 18 \\
Mediana & 4320 & 3460 & 3720 & 3125 \\
Média & 4099 & 3313 & 3794 & 3146 \\
Mínimo & 2450 & 1880 & 2980 & 2280 \\
Máximo & 4740 & 3850 & 5250 & 4330 \\
Coef. Var. & 0,15 & 0,16 & 0,14 & 0,15 \\
Desvio padrão & 607,9 & 533,7 & 527,9 & 473,3 \\
\hline
\end{tabular}

Tabela 29 - Resultados de SSV e SST nos lodos dos tanques de aeração - Fase 3

\section{Lodo Ativado}

\begin{tabular}{ccccc} 
& $\begin{array}{c}\text { SST } \\
(\mathbf{m g} / \mathbf{L})\end{array}$ & $\begin{array}{c}\text { SSV } \\
(\mathbf{m g} / \mathbf{L})\end{array}$ & $\begin{array}{c}\text { SST } \\
(\mathbf{m g} / \mathbf{L})\end{array}$ & $\begin{array}{c}\text { SSV } \\
(\mathbf{m g} / \mathbf{L})\end{array}$ \\
\hline Núm. dados & 3 & 3 & 3 & 3 \\
Mediana & 1590 & 1270 & 2050 & 1620 \\
Média & 1867 & 1573 & 2050 & 1710 \\
Mínimo & 1340 & 1160 & 1560 & 1360 \\
Máximo & 2670 & 2290 & 2540 & 2150 \\
Coef. Var. & 0,38 & 0,40 & 0,24 & 0,24 \\
Desvio padrão & 706,8 & 623,1 & 490,0 & 402,6 \\
\hline
\end{tabular}




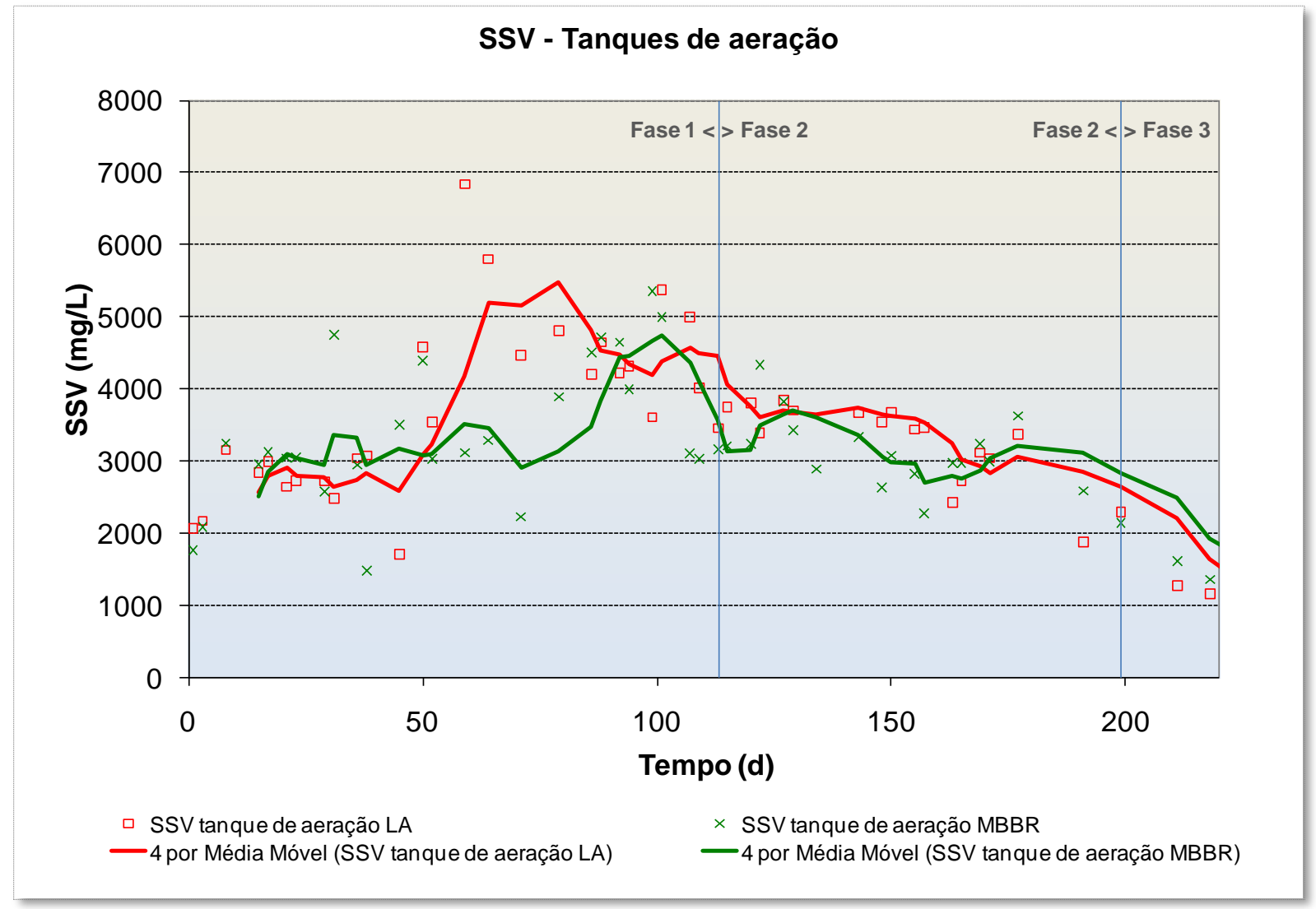

Figura 51 - Séries históricas de concentração de SSV - Fase 1

Pode ser observado que em ambos os reatores ocorreram elevações da concentração de sólidos a valores acima do esperado durante a Fase 1. No caso do lodo ativado, o incremento na biomassa foi fruto da intenção de se procurar promover a nitrificação. No caso do MBBR, ocorreu um descontrole do processo no final do período de observações em função de variações nas características do esgoto decorrente de intenso processo de lavagem no restaurante do CRUSP.

$\mathrm{Na}$ fase 2 o controle do processo não sofreu perturbações significativas e foi possível manter a concentração prevista de sólidos e realizar adequadamente o controle da idade do lodo. A fase três ocorreu já em período de férias e os estudantes residentes do CRUSP, em sua maioria, deixaram o campus. Nesse período começaram a ocorrer as complicações em função da falta de disponibilidade de esgoto. A biomassa em suspensão de ambos os sistemas diminuiu muito em função da falta de substrato. 


\subsubsection{Caracterização Quantitativa da biomassa aderida}

Com relação à quantificação de biomassa aderida no MBBR, desenvolveu-se metodologia de remoção por raspagem de $40 \mathrm{~mL}$ de anéis (35 peças) com escova especial de uso odontológico. Foram realizadas cinco campanhas, tendo sido obtidos os resultados apresentados na Tabela 30.

Tabela 30 - Resultados da quantificação da biomassa aderida

\begin{tabular}{ccccccc}
\hline Data & \multicolumn{3}{c}{$\mathbf{S S T}$} & \multicolumn{3}{c}{$\mathbf{S S V}$} \\
& $(\mathbf{g} / \mathbf{4 0} \mathbf{m})$ & $(\mathbf{m g} / \mathbf{L})$ & $\left(\mathbf{g ~ S S T} / \mathbf{m}^{2}\right)$ & $\mathbf{( g / 4 0 m L})$ & $(\mathbf{m g} / \mathbf{L})$ & $\left(\mathbf{g ~ S S V / \mathbf { m } ^ { 2 } )}\right.$ \\
\hline $02 / 09 / 2010$ & 0,1670 & 4.175 & 13,92 & 0,1358 & 3395 & 11,32 \\
$14 / 09 / 2010$ & 0,1620 & 4.050 & 13,50 & 0,1326 & 3315 & 11,05 \\
$\mathbf{2 8 / 0 9 / 2 0 1 0}$ & 0,1745 & 4.363 & 14,54 & 0,1434 & 3585 & 11,95 \\
$19 / 10 / 2010$ & 0,1771 & 4.428 & 14,76 & 0,1472 & 3680 & 12,27 \\
$04 / 11 / 2010$ & 0,0908 & 2.270 & 7,57 & 0,0755 & 1888 & 6,29 \\
\hline
\end{tabular}

Considerando-se a área superficial específica dos suportes Kaldnes do tipo K1 de $300 \mathrm{~m}^{2} / \mathrm{m}^{3}$, resultaram valores de quantidade de SSV de até $12,27 \mathrm{~g} \mathrm{SSV} / \mathrm{m}^{2}$ de biofilme, valor bastante coerente, inferior ao limite máximo de $15 \mathrm{~g} \mathrm{SSV} / \mathrm{m}^{2}$, recomendado pela NBR - 12.209 da ABNT. Os valores obtidos aumentaram gradativamente até a campanha de 19/10/2010, que resultou no valor máximo. O resultado de 04/11/2010 já indicou redução acentuada da quantidade de biomassa aderida, denunciando a interferência das condições operacionais dos sistemas.

Considerando-se que os volumes de suportes plásticos introduzidos na câmara anóxica e no tanque aerado foram de, respectivamente, $30 \%$ e $50 \%$ de seus volumes úteis, as contribuições provenientes da biomassa aderida resultam nos valores apresentados na Tabela 31. 
Tabela 31 - Contribuições de SSV e SST da biomassa aderida

\begin{tabular}{ccccc}
\hline & \multicolumn{2}{c}{ Anóxica } & \multicolumn{2}{c}{ Aeróbia } \\
Data & $\begin{array}{c}\text { SST } \\
(\mathbf{m g} / \mathbf{L})\end{array}$ & $\begin{array}{c}\text { SSV } \\
(\mathbf{m g} / \mathbf{L})\end{array}$ & $\begin{array}{c}\text { SST } \\
(\mathbf{m g} / \mathbf{L})\end{array}$ & $\begin{array}{c}\text { SSV } \\
(\mathbf{m g} / \mathbf{L})\end{array}$ \\
\hline $02 / 09 / 2010$ & 1.253 & 1.019 & 2.088 & 1.698 \\
$14 / 09 / 2010$ & 1.215 & 995 & 2.025 & 1.658 \\
$28 / 09 / 2010$ & 1.309 & 1.076 & 2.181 & 1.793 \\
$19 / 10 / 2010$ & 1.328 & 1.104 & 2.214 & 1.840 \\
$04 / 11 / 2010$ & 681 & 566 & 1.135 & 944 \\
\hline
\end{tabular}

5.2.3.2.1 Avaliação da quantidade relativa de biomassa aderida em relação à suspensa.

Os resultados da determinação do incremento de biomassa total devido á introdução dos suportes móveis representando biomassa em aderida em relação à biomassa em suspensão são apresentados na Tabela 32.

Tabela 32 - Quantidades relativas de biomassa no tanque de aeração - MBBR.

\begin{tabular}{cccccc}
\hline Data & Fase & $\begin{array}{c}\text { Biomassa } \\
\text { Aderida } \\
(\mathbf{m g} / \mathbf{L})\end{array}$ & $\begin{array}{c}\text { Biomassa } \\
\text { Suspensa } \\
(\mathbf{m g} / \mathbf{L})\end{array}$ & $\begin{array}{c}\text { Biomassa } \\
\text { Total } \\
(\mathbf{m g} / \mathbf{L})\end{array}$ & $\begin{array}{c}\text { Acréscimo } \\
\text { Aderida } \\
(\%)\end{array}$ \\
\hline $02 / 09 / 2010$ & 1 & 1.698 & 3.950 & 5.648 & $43 \%$ \\
$14 / 09 / 2010$ & & 1.658 & 3.170 & 4.828 & $52 \%$ \\
\hline $28 / 09 / 2010$ & & 1.793 & 3.820 & 5.613 & $47 \%$ \\
$19 / 10 / 2010$ & 2 & 1.840 & 2.630 & 4.470 & $70 \%$ \\
$04 / 11 / 2010$ & & 944 & 2.970 & 3.914 & $32 \%$ \\
\hline
\end{tabular}

A quantidade de biomassa em suspensão se manteve estável durante o período em que ocorreram as quantificações de biomassa aderida, como fruto do controle de descarte do lodo, para cumprimento da programação experimental. A quantidade de biomassa aderida manteve-se estável nas análises iniciais, e apresentou forte decréscimo na última análise, refletindo o impacto das perturbações operacionais ocorridas nesse período, ou seja, a porção final da segunda fase que transcorreu até o dia 09/12/2010. Não foram realizadas análises de quantificação da biomassa na fase 3. 
A presença de baixas concentrações de alcalinidade pode ter sido um dos fatores que provocaram a instabilidade e declínio da quantidade de biomassa aderida no período final da segunda fase.

\subsubsection{Caracterização Qualitativa da microfauna dos módulos experimentais}

Com relação à microscopia do lodo ativado e da biomassa suspensa no MBBR, foram realizadas 04 campanhas de amostragem e análises de diversidade biológica, gêneros e espécies detectados e densidade total. Não foram observadas diferenças em relação à diversidade biológica nos módulos experimentais. Entretanto, houve uma diferença significativa entre as concentrações de organismos entre os módulos.

Nas Tabelas 33 e 34 são apresentados os resultados das análises de diversidade biológica, gêneros e espécies detectados e densidade total.

Tabela 33 - Resultados da Microscopia - MBBR

\begin{tabular}{|c|c|c|c|c|}
\hline Data & $\begin{array}{l}\text { Diversidade } \\
\text { Biológica }\end{array}$ & Gêneros e Espécies & $\begin{array}{l}\text { Densidade } \\
\text { Total } \\
\text { (org } / \mathrm{mL} \text { ) }\end{array}$ & $\begin{array}{c}\text { Média e Desvio } \\
\text { Padrão } \\
\text { (org } / \mathrm{mL} \text { ) }\end{array}$ \\
\hline $27 / 05 / 10$ & $\begin{array}{l}\text { Ciliados Pedunculados } \\
\text { Ciliado de Vida Livre } \\
\text { Suctoria } \\
\text { Amebas } \\
\text { Nematoides }\end{array}$ & $\begin{array}{l}\text { Epistylis plicatilis, } \\
\text { Operacularia coarctata } \\
\text { Blepharisma lateritum } \\
\text { Podophrya fixa } \\
\text { Amoeba radiosa } \\
\text { Rabditis sp }\end{array}$ & 2580 & $860( \pm 340)$ \\
\hline $17 / 06 / 10$ & $\begin{array}{l}\text { Ciliados Pedunculados } \\
\text { Suctoria } \\
\text { Amebas }\end{array}$ & $\begin{array}{l}\text { Epistylis plicatilis, } \\
\text { Operacularia coarctata } \\
\text { Podophrya fixa } \\
\text { Amoeba radiosa }\end{array}$ & 3080 & $1027( \pm 199)$ \\
\hline $27 / 07 / 10$ & Ciliados Pedunculados & $\begin{array}{l}\text { Epistylis plicatilis, } \\
\text { Operacularia coarctata } \\
\text { Vorticella microstoma }\end{array}$ & 480 & $160( \pm 69)$ \\
\hline $26 / 08 / 10$ & $\begin{array}{l}\text { Ciliados Pedunculados } \\
\text { Rotífero } \\
\text { Nematoides }\end{array}$ & $\begin{array}{l}\text { Operacularia coarctata } \\
\text { Lecane sp, } \\
\text { Epiphanes sp } \\
\text { Rabditis sp }\end{array}$ & 1980 & $660( \pm 191)$ \\
\hline
\end{tabular}


Tabela 34 - Resultados da Microscopia - Lodo Ativado

\begin{tabular}{|c|c|c|c|c|}
\hline Data & $\begin{array}{l}\text { Diversidade } \\
\text { Biológica }\end{array}$ & Gêneros e Espécies & $\begin{array}{l}\text { Densidade } \\
\text { Total } \\
\text { (org } / \mathrm{mL} \text { ) }\end{array}$ & $\begin{array}{c}\text { Média e Desvio } \\
\text { Padrão } \\
\text { (org/mL) }\end{array}$ \\
\hline $27 / 05 / 10$ & $\begin{array}{l}\text { Ciliados Pedunculados } \\
\text { Suctoria } \\
\text { Amebas } \\
\text { Rotíferos }\end{array}$ & $\begin{array}{l}\text { Epistylis plicatilis, } \\
\text { Operacularia coarctata } \\
\text { Podophrya fixa } \\
\text { Amoeba radiosa } \\
\text { Asplanchna sp, Lecane } \\
\text { sp }\end{array}$ & 210 & $70( \pm 44)$ \\
\hline $17 / 06 / 10$ & $\begin{array}{l}\text { Ciliados Pedunculados } \\
\text { Suctoria } \\
\text { Amebas }\end{array}$ & $\begin{array}{l}\text { Operacularia coarctata } \\
\text { Podophrya fixa } \\
\text { Amoeba radiosa }\end{array}$ & 290 & $97( \pm 72)$ \\
\hline $27 / 07 / 10$ & $\begin{array}{l}\text { Ciliados Pedunculados } \\
\text { Flagelados }\end{array}$ & $\begin{array}{l}\text { Operacularia coarctata } \\
\text { Clamydomonas sp }\end{array}$ & 420 & $140( \pm 190)$ \\
\hline $26 / 08 / 10$ & $\begin{array}{l}\text { Ciliados Pedunculados } \\
\text { Rotifero }\end{array}$ & $\begin{array}{l}\text { Operacularia coarctata } \\
\text { Epiphanes sp }\end{array}$ & 750 & $250( \pm 303)$ \\
\hline
\end{tabular}

Provavelmente no MBBR, com a presença dos suportes plásticos, disponibiliza-se suporte para desenvolvimento de microfauna aderida como ciliados pedunculados, favorecendo um melhor desempenho do sistema (Minegatti, 2008). Foram feitas também contagens de bactérias nitrificantes. Como esperado, as densidades de nitritantes e nitratantes resultaram mais elevadas no MBBR e, neste, não houve diferença entre as densidades na biomassa suspensa e aderida.

\subsubsection{Monitoramento dos Lodos nos Reatores Mediante Sensores}

Foram instalados nos dois reatores sensores de Temperatura, $\mathrm{pH}$ e Oxigênio Dissolvido (tanques de aeração). A Figura 52 apresenta os resultados do monitoramento da temperatura nos reatores. Nas Figuras 53 e 54 são registrados os resultados de oxigênio dissolvido e pH para os sistemas de Lodo Ativado e MBBR. 


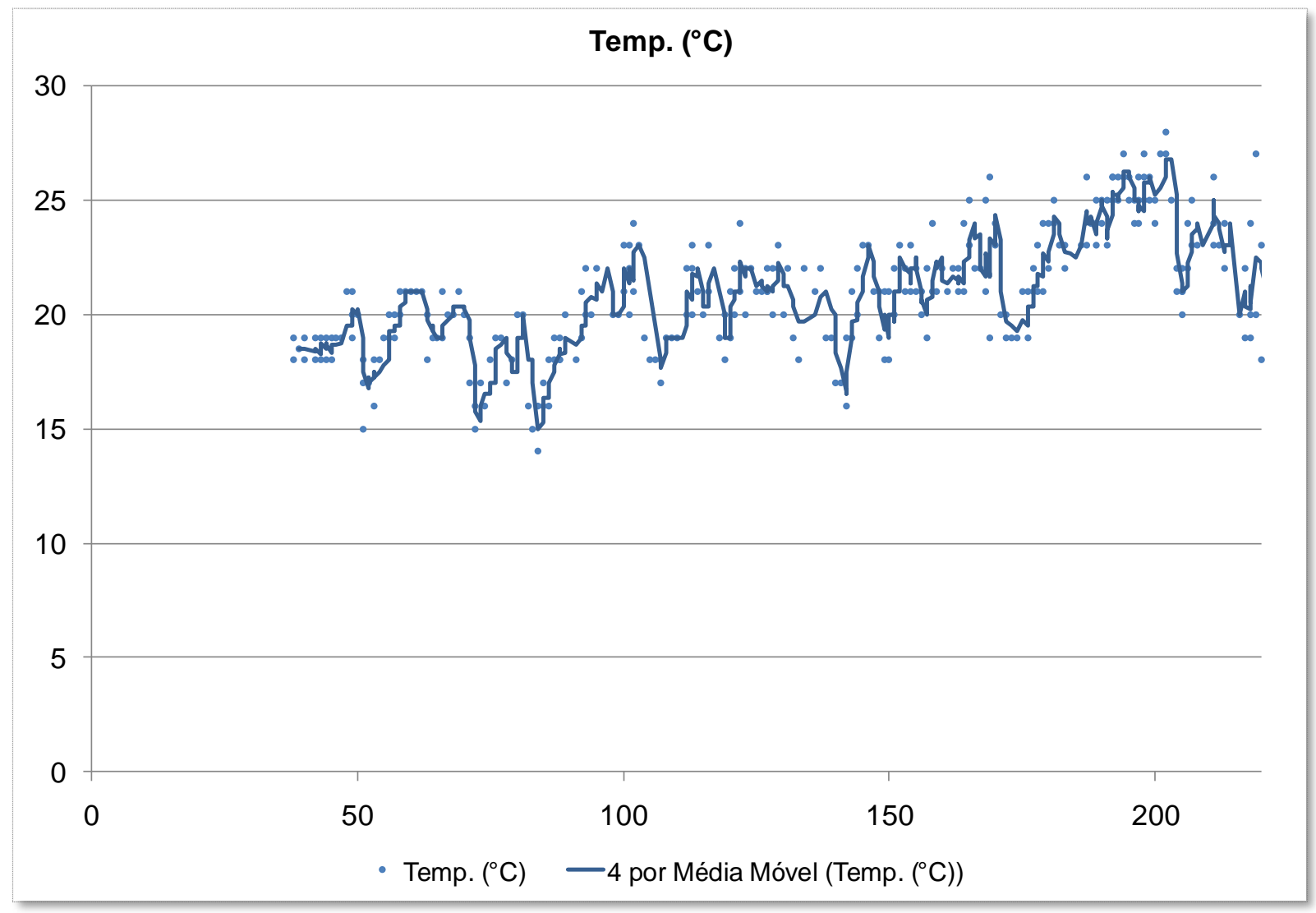

Figura 52 - Monitoramento de temperatura nos tanques.

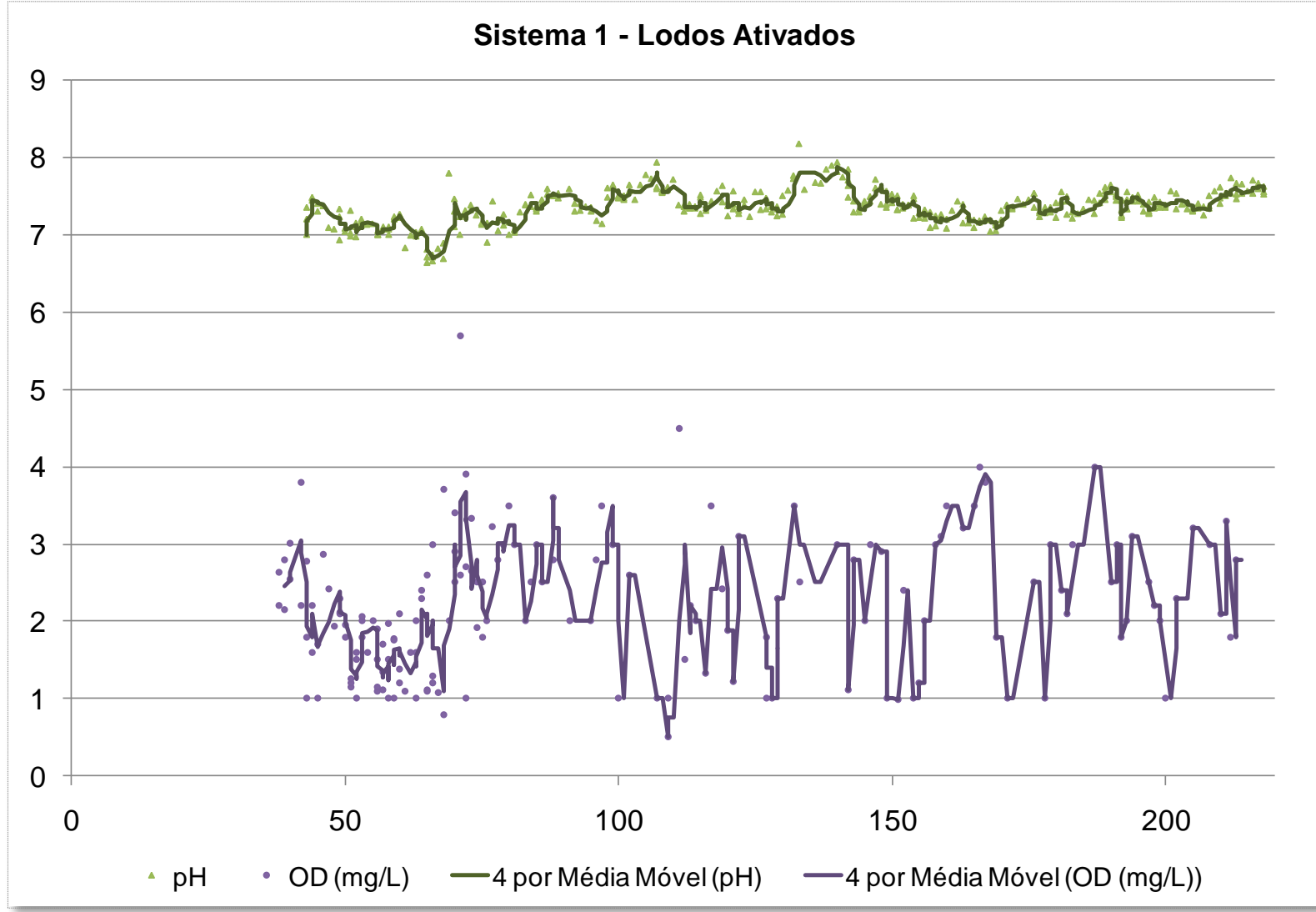

Figura 53 - Monitoramento de OD e pH por sensores instalados nos tanques - Lodo Ativado. 


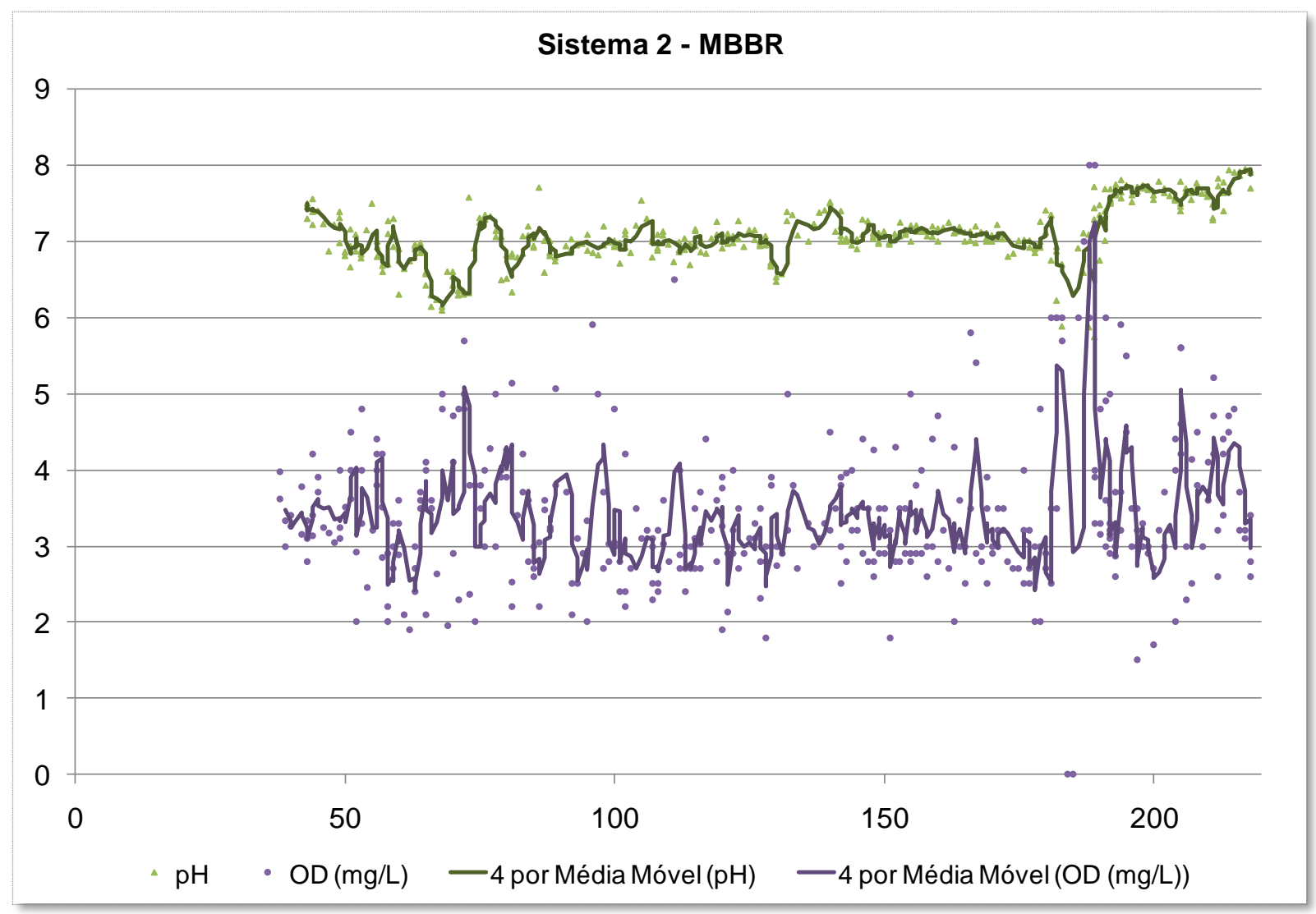

Figura 54 - Monitoramento de OD e pH por sensores instalados nos tanques - MBBR.

\subsection{Verificação dos Parâmetros com Foco na Biomassa Aderida}

Em análises de sistemas híbridos o desafio é a determinação das parcelas de contribuição ao tratamento atribuídas a cada fração de biomassa, aderida ou em suspensão. A metodologia de projeto mais adequada é realmente a utilização de modelos matemáticos, que apesar de incorporarem maior complexidade ao processo de projeto e verificação de sistemas, podem ser calibrados e utilizados de maneira flexível e dinâmica, até mesmo durante a operação dos sistemas.

Métodos empíricos são baseados na experiência de cada fabricante e devem ser utilizados com cautela porque se baseiam em um determinado tipo de meio suporte e nas condições específicas dos sistemas que geraram as informações.

Nesse trabalho, para uma estimativa da quantidade de substrato consumida por cada fração de biomassa serão utilizados os valores orientativos das frações de remoção pelo biofilme, de acordo com a idade do lodo em relação à biomassa em 
suspensão, apresentados na Tabela 2, baseados em análises feitas por modelos cinéticos do processo.

Para a fase 1, de idade do lodo aeróbia com referência à biomassa em suspensão é de aproximadamente 6 dias, será utilizada um fração de 12,5\% da DQO e 35\% do nitrogênio amoniacal para estimativa da contribuição do biofilme. Esses valores foram calculados como uma interpolação linear dos valores informados na Tabela 2 para idades do lodo de 4 e 8 dias em relação à biomassa em suspensão. Da mesma forma, para a Fase 2 que operou com idade do lodo aeróbia de aproximadamente 4 dias os valores foram de $25 \%$ e $50 \%$, de acordo com a própria tabela, e para a fase 3 os valores foram de $37,5 \%$ e $65 \%$, para uma idade do lodo aeróbia de aproximadamente 3 dias.

Também são utilizados esses valores para a estimativa das taxas de aplicação relativas de substrato, correspondentes a cada fração de biomassa. As cargas orgânicas superficiais calculadas de acordo com essa orientação resultaram nos valores apresentados na forma de gráfico das séries históricas corrigidas dos valores de $\mathrm{DQO}$ e $\mathrm{NH}_{3}-\mathrm{N}$ para as frações de substrato destinadas à biomassa aderida nas Figuras 55 e 56.

Pelos gráficos das Figuras 55 e 56 podem ser observadas as cargas estimadas de DQO e de nitrogênio amoniacal aplicadas sobre a biomassa aderida resumidas na Tabela 35.

Tabela 35 - Contribuições de SSV e SST da biomassa aderida

\begin{tabular}{|c|c|c|c|}
\hline Fase & $\begin{array}{c}\text { DQO } \\
\left(g / m^{2} . d\right)\end{array}$ & $\begin{array}{l}\mathrm{DBO}_{5,20}{ }^{*} \\
\left(\mathrm{~g} / \mathrm{m}^{2} . \mathrm{d}\right)\end{array}$ & $\begin{array}{c}\mathrm{NH}_{4}-\mathrm{N} \\
\left(\mathrm{g} \mathrm{NH}_{4}-\mathrm{N} / \mathrm{m}^{2} . \mathrm{d}\right)\end{array}$ \\
\hline 1 & 1,0 & 0,5 & 0,3 \\
\hline 2 & 3,0 a 4,0 & 1,5 a 2,0 & 0,6 a 1,0 \\
\hline 3 & 7,0 a 8,0 & 3,5 a 4,0 & 1,0 a 1,4 \\
\hline
\end{tabular}




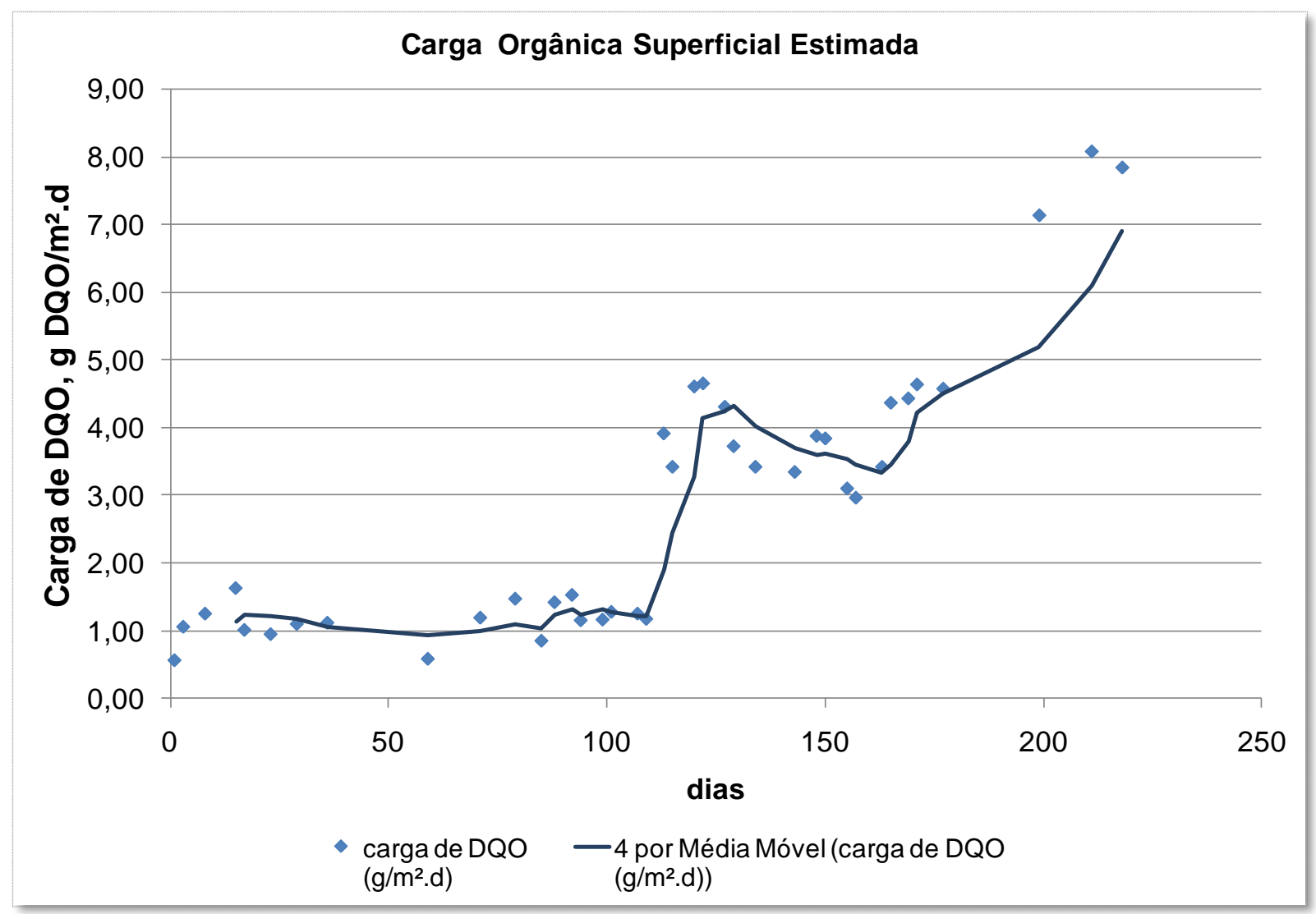

Figura 55 - Série histórica calculada para a taxa de aplicação superficial de DQO referentes à fração de substrato calculada para a biomassa aderida.

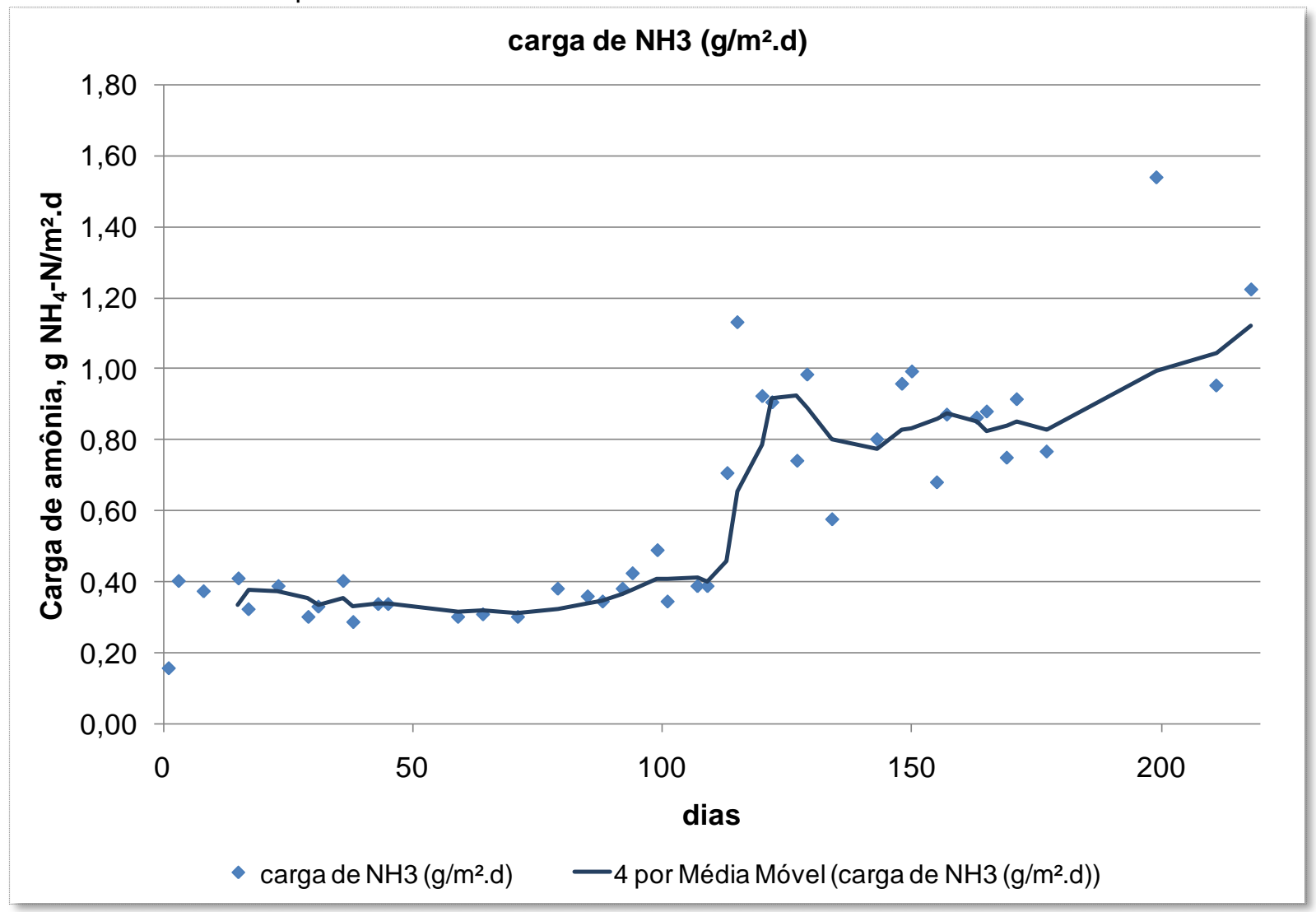

Figura 56 - Série histórica calculada para a taxa de aplicação superficial de amônia referentes à fração de substrato calculada para a biomassa aderida. 
Hem et al. (1994) obteve, para remoção simultânea de DBO e nitrificação num sistema IFAS (condição simulada na presente análise), a $15^{\circ} \mathrm{C}$ e com concentrações de oxigênio dissolvido no intervalo de 4 a $6 \mathrm{mg} \mathrm{OD/L}$, em que as variações de cargas de DBO resultaram em taxas de nitrificação diferentes, os resultados descrito abaixo:

- Taxas de nitrificação de 0,7 a $1,2 \mathrm{~g} \mathrm{~N} / \mathrm{m}^{2}$.d para carga de DBO de 1 a 2 $\mathrm{g} / \mathrm{m}^{2} . \mathrm{d}$;

- Taxas de nitrificação de 0,3 a $0,8 \mathrm{~g} \mathrm{~N} / \mathrm{m}^{2}$.d para carga de DBO de 2 a 3 $\mathrm{g} / \mathrm{m}^{2} . \mathrm{d}$;

- Nitrificação inexistente para carga de DBO maior que $5 \mathrm{~g} / \mathrm{m}^{2} . d$.

As cargas do presente estudo chegaram aos limites das remoções obtidas por Hem, principalmente na Fase 3, em que, mesmo com cargas relativamente altas de matéria orgânica, em se tratando de um sistema que objetivava também a remoção de nitrogênio, as cargas estimadas de nitrogênio amoniacal aplicadas à biomassa aderida, e hipoteticamente removidas por ela, foram também altas.

Recalculando as taxas de nitrificação e carga superficial de amônia segundo essas orientações, obtem-se o gráfico da Figura 57. Em que pode ser observada alta eficiência em remoção nitrogênio amoniacal até em altas taxas de aplicação superficiais.

Como a nitrificação é muito dependente da temperatura, a operação do sistema IFAS do presente trabalho ocorreu em condições muito mais favoráveis do ponto de vista da cinética das reações. Mas, como em biofilmes muitas vezes o que limita a taxa de fluxo é a transferência de massa e a concorrência por oxigênio também é acirrada entre os dois processos, se houver baixa concentração de oxigênio a nitrificação pode ser limitada. 


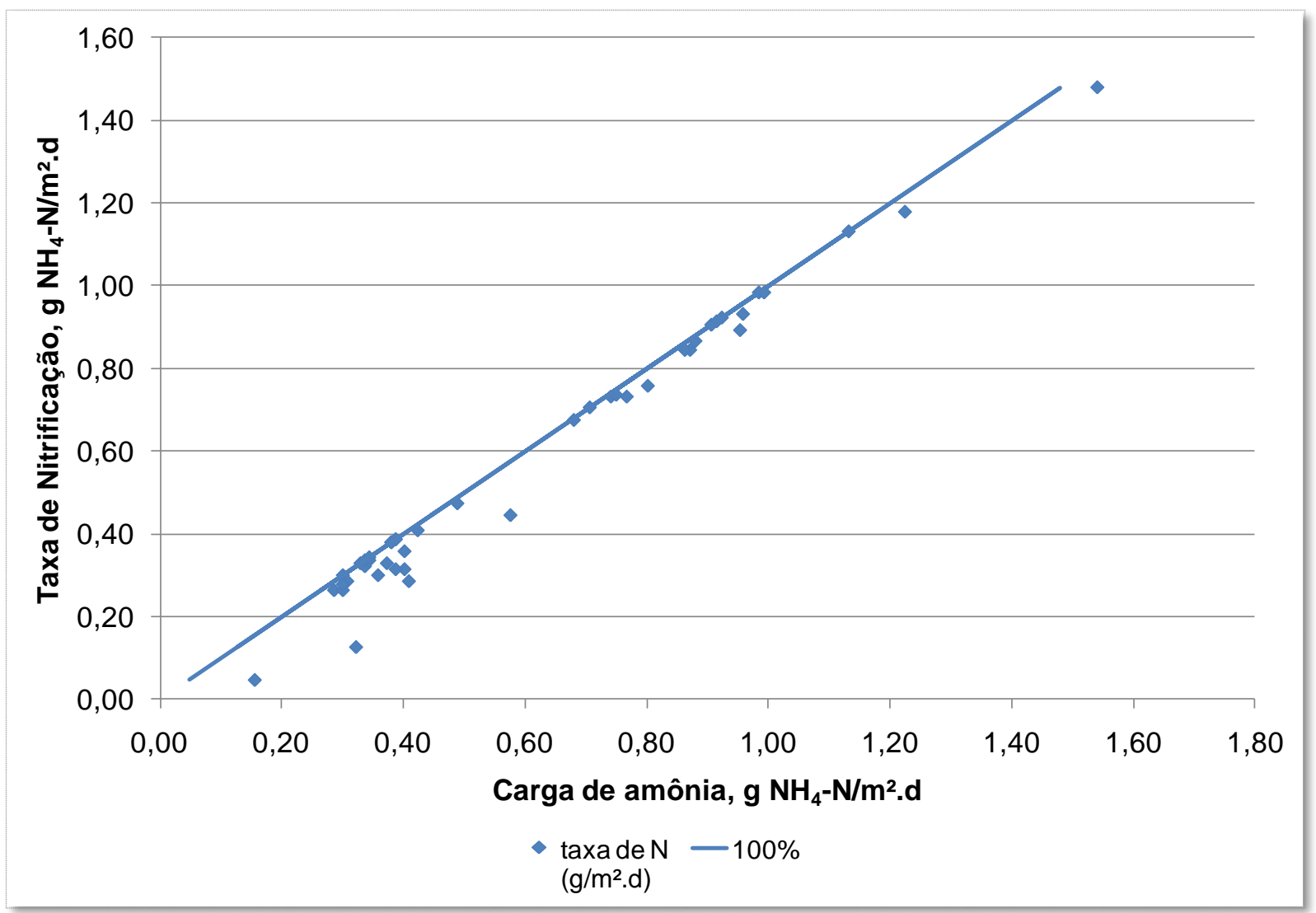

Figura 57- Relação entre a carga de nitrogênio amoniacal e a taxa de nitrificação referentes à fração da biomassa aderida.

De acordo com os resultados das análises de nitrogênio Kjeldahl total e nitrogênio amoniacal a nitrificação ocorreu até a Fase 3, mas perdendo sua eficiência no final do período. Um dos fatores que contribuíram para essa queda de desempenho pode ser a alta solicitação em termos de aplicação superficial de substrato.

\subsection{Discussões}

Para a avaliação do efeito da introdução dos suportes plásticos móveis num sistema de lodo ativado, caracterizando uma configuração híbrida, é necessária a estimativa da intensidade de atividade que cada tipo de biomassa desempenhará no processo, e da integração que as duas formas terão entre si. Fragmentos de biofilme semeiam a biomassa em suspensão e microorganismos suspensos são incorporados na biomassa aderida continuamente. Para essa compreensão do sistema e consideração adequada de todas as variáveis significantes envolvidas é necessária a utilização de um modelo matemático que represente aspectos como a cinética do 
processo, a hidrodinâmica dos reatores e as variáveis ambientais. Existem diversos modelos desenvolvidos para essa aplicação, que podem ser utilizados para projeto e simulação da operação dos sistemas. Consideram o projeto de sistemas novos ou a adequação de plantas existentes. Mas para a correta utilização de um modelo este deve ser calibrado e para isso necessita da determinação de parâmetro que precisam ser investigados de forma analítica e com elementos que representem com grande aproximação as condições de operação do sistema em estudo.

Os resultados apresentados na seção anterior mostram que as condições operacionais impostas à biomassa aderida estavam próximas ao limite do sistema quanto à nitrificação considerando as hipóteses de distribuição das remoções por tipo de fixação de biomassa. As taxas de aplicação superficiais recomendadas apenas para remoção de matéria orgânica são muito superiores. Entretanto, a remoção de nitrogênio foi observada no sistema 2 durante todo o período experimental válido, considerando ainda a ocorrência de efeitos desestabilizadores do processo, alguns deles já mencionados, refletidos nos resultados apresentados. Muitas vezes essas perturbações foram impactantes para o sistema de lodo ativado mas poucas vezes sensíveis nas análises do sistema IFAS, até o colapso do término da terceira fase. Podem ser relacionados incidentes como:

- falta de substrato provocada pela descontinuidade da contribuição por parte dos moradores do CRUSP e restaurante universitário, acorrida de forma mais acentuada no mês de Julho e Agosto/2010 (greve na USP), feriados prolongados e "semana da pátria" e mês de Dezembro/2010 já iniciando as férias de verão;

- Perda de sólidos dos sistemas provocados pela operação dos raspadores em velocidades acima das adequadas em situação provisória enquanto transcorriam manutenções de componentes;

- Cargas de choque em termos de concentrações de matéria orgânica, NKT e óleos e graxas provocadas por operações não comunicadas de limpeza das tubulações de esgotamento do restaurante universitário;

- Altas concentrações de NKT ocorridas durante o mês de Setembro/2010, atingindo valores de até $120 \mathrm{mg} / \mathrm{L}$ que podem ser decorrentes do término da greve e retomada da operação dos entes contribuintes de esgoto; 
- Manutenção de equipamentos como bombas de deslocamento positivo e inversores de frequência.

Do ponto de vista da avaliação comparativa dos sistemas esses imprevistos foram importantes para a identificação do potencial de resistência a variações das condições operacionais apresentado por sistemas MBBR. 


\section{CONCLUSÕES E RECOMENDAÇÕES}

Como efeito da introdução dos suportes plásticos móveis nos reatores biológicos do sistema IFAS observou-se o desempenho superior alcançado em termos de eficiências e estabilidade operacional. As eficiências de remoção de matéria orgânica, sólidos em suspensão e de nitrogênio amoniacal foram maiores e mais constantes ao longo do período experimental.

A eficiência de remoção de DQO se manteve por volta de $90 \%$ ao longo das três fases experimentais para o sistema IFAS, e ligeiramente inferior no sistema de lodo ativado durante a Fase 1, com $80 \%$. De modo geral a variância foi menor no sistema IFAS. Quanto às remoções de SST o sistema IFAS também teve desempenho melhor atribuído à característica diferenciada de crescimento da biomassa, parte sob a forma de biofilme, que quando desprendido do suporte, contribui para a sedimentabilidade geral da massa de sólidos aplicada sobre o decantador secundário. $O$ efeito da variação das idades do lodo teve pouco impacto sobre as remoções de matéria orgânica, como esperado, já que os sistemas estavam ainda longe dos seus limites nesse aspecto.

Observou-se que a nitrificação ocorreu sempre de forma completa no sistema IFAS, com eficiências superiores a $90 \%$ ao longo de praticamente todo o período experimental, enquanto o sistema de lodo ativado apresentou eficiência alta apenas durante a segunda fase experimental. Na primeira Fase ocorreram temperaturas mais baixas, típicas do inverno no mês de Agosto e na Fase 3 a idade do lodo aeróbia de 3,2 dias já é baixa, se considerada a manutenção das bactérias nitrificantes no sistema.

Os resultados de desempenho confirmam a vantagem da tecnologia como potencial para ampliação e adequação de plantas de tratamento existentes para a remoção de nitrogênio.

Conforme discutido no item 5.3 a variação da idade do lodo, calculada com base apenas na biomassa em suspensão, provoca efeitos não apenas sobre a quantidade de sólidos em suspensão, quanto na composição dessa biomassa. Como consequência, as parcelas de substrato removidas por cada uma das frações de biomassa, suspensa ou aderida, também variam. Nos experimentos realizados as 
taxas de aplicação que se estima terem sido aplicadas à biomassa aderida na Fase 3 foram altas se comparadas a condições recomendadas de projeto para temperaturas próximas a $15^{\circ} \mathrm{C}$. Como naquele período ocorreram temperaturas altas do verão, da ordem de 20 a $25^{\circ} \mathrm{C}$, a capacidade do sistema também foi maior pela maior velocidade dos processos da cinética microbiana.

A quantificação da biomassa demonstrou que, para as condições em que foram conduzidos os estudos, a contribuição da biomassa aderida em quantidade resultou em uma contribuição de aproximadamente $70 \%$, na campanha realizada no dia 19/10/2010, correspondente ao $148^{\circ}$ dia do período experimental e situado na metade do tempo decorrido da Fase 2 em que se considera que os sistemas apresentavam as situações mais estáveis e coerentes com o seu comportamento previsto. Nesse período ocorreram poucas perturbações operacionais se comparado aos demais.

Além do efeito comparativo em relação à adição de suportes móveis a um sistema de lodo ativado convencional, a pesquisa também traz como benefício a apresentação de resultados de desempenho nas condições ambientais típicas do município de São Paulo com invernos relativamente frios e verões quentes, considerando os mesmos gradientes de temperatura diários e a utilização de esgotos sanitários semelhantes, com exceção das concentrações de NKT que se mostraram muito maiores do que as típicas de São Paulo, situadas em torno de $40 \mathrm{mg} \mathrm{N} / \mathrm{L}$, fato que constitui uma vocação ainda maior para utilização na RMSP.

Não é correta a comparação das duas tecnologias apenas em termos de taxas de aplicação e de remoção de substratos. A estabilidade e robustez operacionais obtidas com o MBBR são características de grande peso num estudo de viabilidade que se possa desenvolver para escolha entre tecnologias porque muitas vezes são utilizados coeficientes de segurança em projetos que poderiam ser reduzidos por conta desses atributos.

O desafio é a busca de condições operacionais que resultem em maior economia em termos de insumos para a implantação e operação dos sistemas. 


\section{REFERÊNCIAS BIBLIOGRÁFICAS}

APHA/AWWA/WEF, 2005, Standard Methods for the Examination of Water and Wastewater, $21^{\text {a }}$ edição, American Public Health Association, Washington, D.C.

BRANCO, S. M., 1986, Hidrobiologia Aplicada à Engenharia Sanitária, 3ª edição, CETESB - Companhia Tecnológica de Saneamento Ambiental/ASCETESB Associação de Funcionários da CETESB, São Paulo.

EKAMA, G. A., PITMAN, A. R., SMOLLEN, M. e MARAIS, GvR, 1984, Theory, Design and Operation of Nutrient Removal Activated Sludge Processes, Water Research Commission, Pretoria, África do Sul.

GAUL, T., MARKER, S. e KUNST, S., 2005, Start-up of moving bed biofilm reactors for deammonification: the role of hydraulic retention time, alkalinity and oxygen supply. Water Science \& Technology. Vol $52 \mathrm{~N}^{\circ} 7 \mathrm{pp}$ 127-133.

GRADY, L. E., DAIGGER, G. T., LIM, H., 1999, Biological Wastewater Treatment, $2^{\mathrm{a}}$ edição, Marcel Dekker, Nova Yorque.

HEM, L. J., ØDEGAARD, H., RUSTEN, B., 1994, Nitrification in a Moving Bed Biofilm Reactor - Water Resources (G.B.), 28, 1425-1433.

JORDÃO, E. P., PESSOA, C. A., 2009, Tratamento de Esgotos Domésticos, 5a edição, Associação Brasileira de Engenharia Sanitária e Ambiental, Rio de Janeiro.

LEE, S., BASU, S., TYLER, C. W., WEI, I. W., 2004, Ciliate populations as bioindicators at Deer Island Treatment Plant. Adv. Environ. Research. 8, pp 371-378.

LESSEL, T.H., 1993, Upgrading and nitrification by submerged bio-film reactors - experiences from a large scale plant - Anais da $2^{\text {nd }}$ International Conference Specializae on Biofilm Reactors, Paris, France - pp. 231 - 238.

METCALF \& EDDY, 2003, Wastewater Engineering: Treatment and Reuse, 4 $4^{\mathrm{a}}$ edição, G. Tchobanoglous, F. L Burton, H. D. Stensel (Editores), McGraw-Hill, Nova Yorque. 
MORGENROTH, E., 2008, Modeling Biofilm Systems. Em: Biological Wastewater Treatment - Principles, Modelling, and Design, IWA Publishing, Londres, Inglaterra.

MINEGATTI, D. V., 2008, Caracterização dos Parâmetros de Controle e Avaliação de Desempenho de um Reator Biológico com Leito Móvel (MBBR), dissertação de mestrado, COPPE/UFRJ, Rio de Janeiro.

ØDEGAARD, H., RUSTEN, B., 1993, Wastewater treatment with aerated submerged biological filters, Journal Water Pollution Control Federation, v. 56, $\mathrm{n}$. 5, pp. 424-431.

ØDEGAARD, H., RUSTEN, B., WeStRUM, T., 1994, A New Moving Bed Biofilm Reactor - Applications and Results, Water Science and Technology, v. 29, n. 1011, pp. 157-165.

RUSTEN, B., HEM, L., ØDEGAARD, H., 1995, Nitrification of Municipal Wastewater in Moving-bed Biofilm Reactors - Water \& Enviroment Research, 67, 75-86.

RUSTEN, B., SILJUDALEN, J. G., BUNGUN, S., 1995, Moving Bed Biofilm Reactors for Nitrogen Removal: From Initial Pilot Test to Start-Up of the Lillenhammer WWTP, Water Environment Federation, $68^{\text {th }}$ Annual Conference. USA. October, 1995.

RUSTEN, B; MCCOY, M; PROCTOR, R; SILJUDALEN, JON G., 1998, The innovative moving bed biofilm reactor/Solids contact reaeration process for secundary treatment of municipal wastewater, Water Environment Research, v. 70, n 5, pp 1083-1089.

RUSTEN, B., HELLSTROM, B. G., HELLSTROM, F., SEHESTED, O., SKJELFOSS, E., SVENDSEN, B., 2000, Pilot testing and preliminary design of moving bed biofilm reactors for nitrogen removal at the FREVAR wastewater treatment plant, Water Science and Technology, v. 42, n. 4/5, pp. 13-20.

SEN, D., RANDALL, C. W., JENSEN, K., FAVREN, G., COPITHORN, R. R., YOUNG, T. A., BRINK, W. P., 1994, Design Parameters for Integrated Fixed Film Activated Sludge (IFAS) Processes to Enhance Biological Nitrogen Removal, Proceedings 67th Water Environment Federation Annual Conference and Exposition. 
U.S. EPA, 1993, Nitrogen Control Manual, EPA-625/R-93-010; Office of Research and Development, U.S. Environmental Protection Agency, Washington, D.C.

WEF/ASCE/EWRI, 2005, Biological Nutrient Removal (BNR) Operation in Wastewater Treatment Plants, Manual of Practice No. 29, Water Environment Federation, Alexandria, Virginia.

WEF/ASCE/EWRI, 2009, Design of Municipal Wastewater Treatment Plants, $5^{\text {a }}$ edição, Manual of Practice No. 8, Water Environment Federation, Alexandria, Virginia.

VAN HAANDEL, A.; MARAIS, G., 1999, O Comportamento do Sistema de Lodos Ativados - Editora Campina Grande. 